2008

\title{
Does Standards-Based Teacher Evaluation Improve Schools? An Investigation of Teacher Perceptions of Appraisal Systems
}

Joseph A. Batchelor

Cedarville University

Follow this and additional works at: http://digitalcommons.cedarville.edu/education_theses

Part of the Educational Assessment, Evaluation, and Research Commons, and the Teacher Education and Professional Development Commons

\section{Recommended Citation}

Batchelor, Joseph A., "Does Standards-Based Teacher Evaluation Improve Schools? An Investigation of Teacher Perceptions of Appraisal Systems" (2008). Master of Education Research Theses. 44.

http://digitalcommons.cedarville.edu/education_theses/44 
DOES STANDARDS-BASED TEACHER EVALUATION IMPROVE

SCHOOLS? AN INVESTIGATION OF TEACHER PERCEPTIONS OF APPRAISAL SYSTEMS

A thesis submitted in partial fulfillment of the requirements for the degree

Master of Education

By

JOSEPH ALBERT BATCHELOR

B.A. English. Bob Jones University, 1990

2008

Cedarville University 


\section{CEDARVILLE UNIVERSITY}

\section{SCHOOL OF GRADUATE STUDIES}

April 8, 2008

I HEREBY RECOMMEND THAT THE THESIS PREPARED UNDER MY SUPERVISION BY Joseph Albert Batchelor ENTITLED Does Standards-Based Teacher Evaluation Improve Schools? An Investigation of Teacher Perceptions of Appraisal Systems BE ACCEPTED IN PARTIAL FULFILLMENT OF THE REQUIREMENTS FOR THE DEGREE Master of Education.

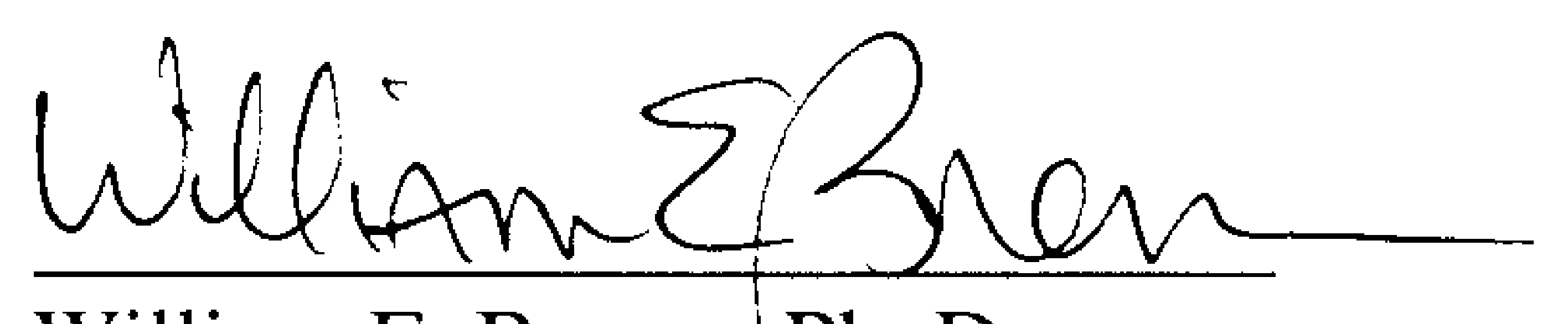

William E. Brown, Ph. D. President

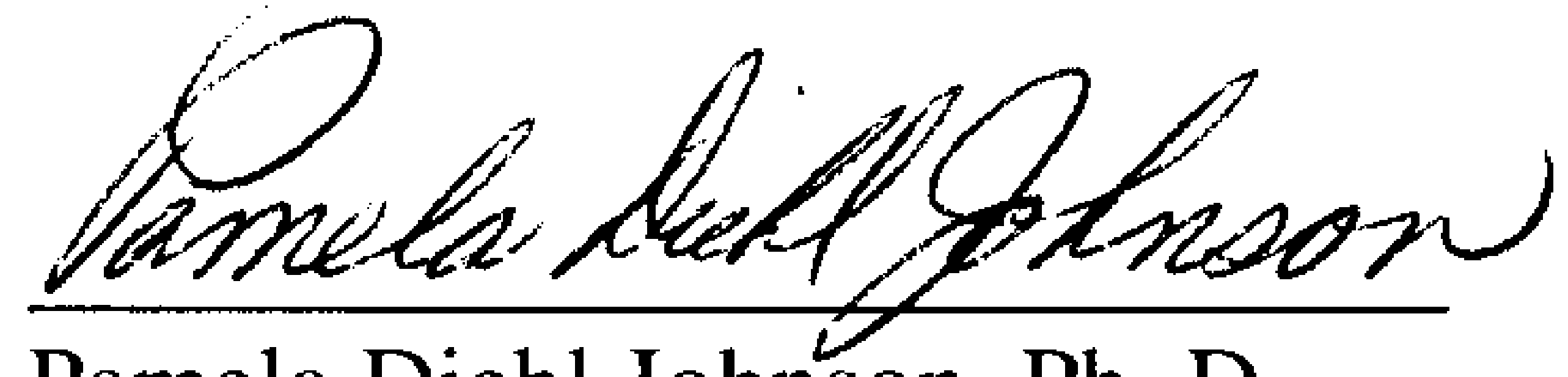

Pamela Diehl Johnson, $\mathrm{Ph}$. D. Dean, School of Social Sciences and Human Performance

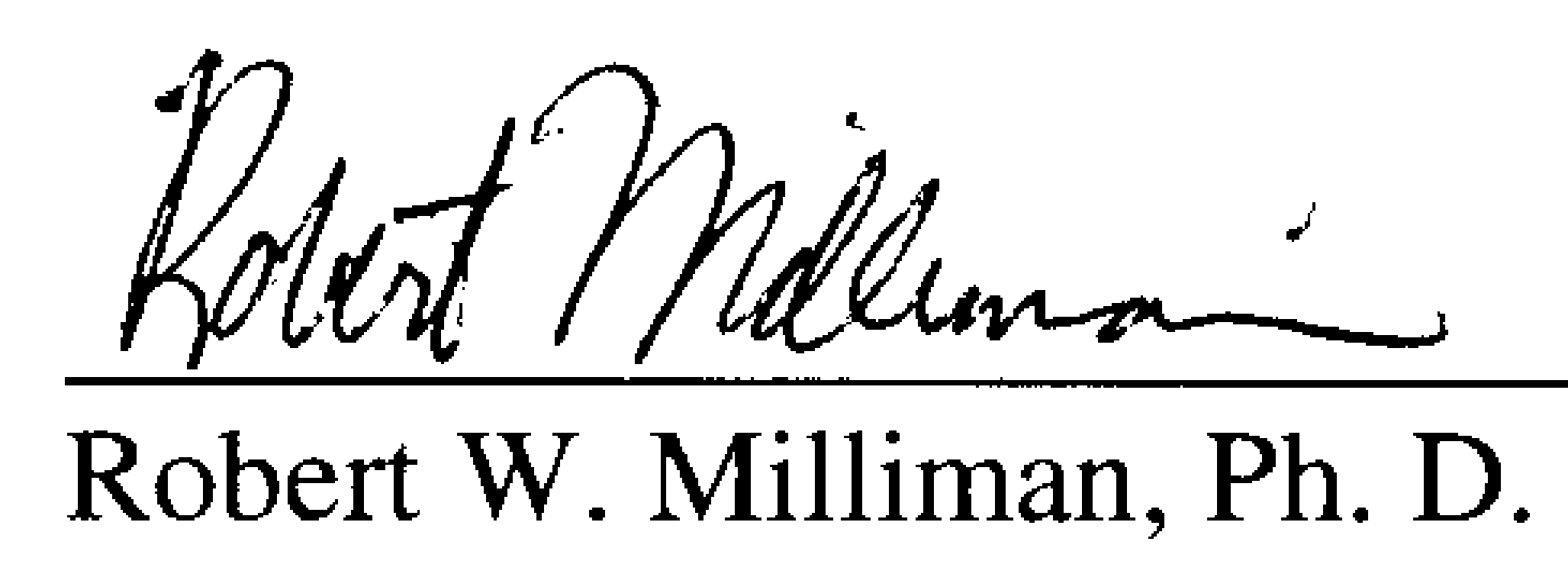

Academic Vice President
Stephen S. Gruber, Ed.D. Education Department Chair Director of the M.Ed. Program Thesis Advisor 


\begin{abstract}
BATCHELOR, JOSEPH ALBERT, M. Ed., Education Department, Cedarville University, 2008. Does Standards-Based Teacher Evaluation Improve Schools? An Investigation of Teacher Perceptions of Appraisal Systems.
\end{abstract}

Three years after implementing a standards-based teacher evaluation system in a private K-12 school, research was conducted to determine what attitudes and perceptions teachers had on the effectiveness of the system. The survey includes questions about the teacher evaluation process and the goals of the test school in implementing the process. The goals for adopting the standards-based teacher evaluation system were (1) increasing student learning, (2) improving instruction, (3) developing a mentoring program, (4) focusing professional development, and (5) facilitating collegiality. The sample for the survey included 87 teachers (group AB) from schools in the Southeast, of which 21 (group B) were from the test school. The other 66 teachers (group A) were used as a control group for comparative purposes. The research concluded that teachers in groups A and B largely agree that their teacher evaluation programs are effective and thorough and there were few statistically significant differences between group A and B with respect to perceptions of teacher evaluation processes. However, there were significant differences found between groups A and B with respect to mentoring programs and professional development programs. It was found that goals for developing mentoring programs and focusing professional development were not yet achieved in the test school. 


\section{TABLE OF CONTENTS}

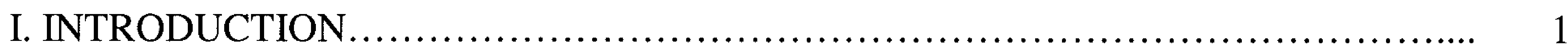

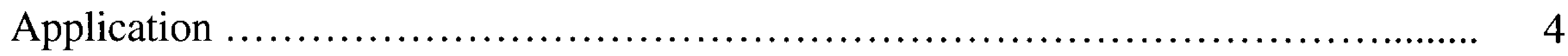

Goals for Evaluation System ................................................... 7

Biblical Integration ........................................................... 11

Statement of Problem / Research Questions .................................. 14

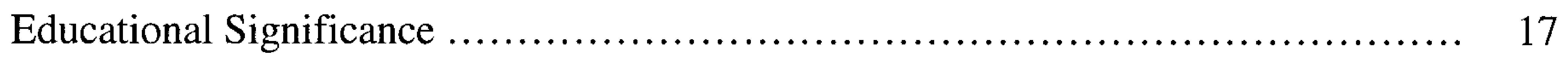

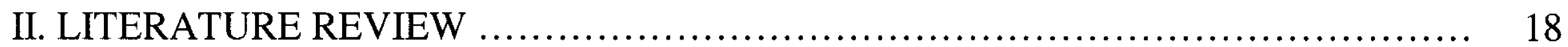

Informational Resources for Teacher Evaluators .............................. 18

Resources That Report Political Issues in Teacher Evaluation ..................... 21

Resources About the Psychology and Sociology of Teacher Evaluation .............. 22

Resources That Link Teacher Evaluation and Student Achievement ................ 23

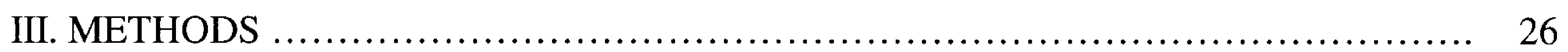

Statistical Analysis ....................................................... 26

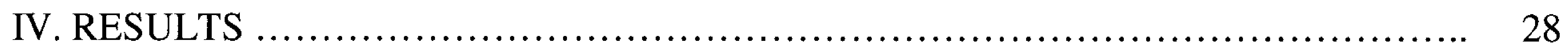

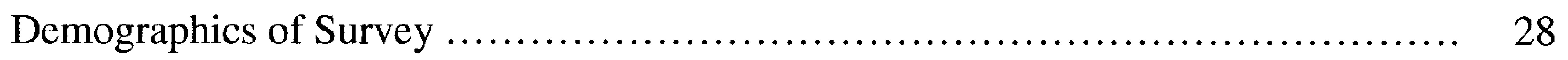

Analyses of Question Results ........................................... 29

Conclusions ................................................................. 58

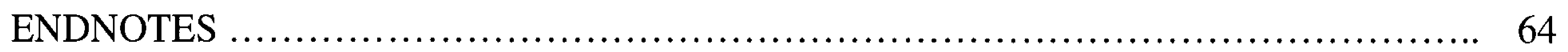

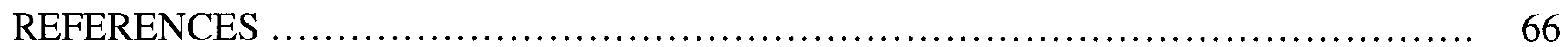

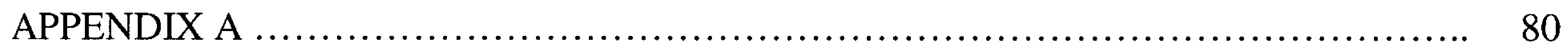

Secondary Teacher Evaluation System Framework ............................ 80 
Sources of Information

Domain I Rubrics: Planning and Preparation ................................. 82

Domain II Rubrics: Classroom Environment ..................................... 85

Domain III Rubrics: Instruction .......................................... 88

Domain IV Rubrics: Professional Responsibilities ............................. 90

Observation Reflection Form ................................................ 94

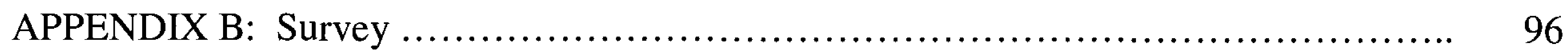




\section{GLOSSARY}

Teacher Evaluation: An appraisal of the qualities of a teacher in delivering instruction.

Standards-Based Teacher Evaluation: The type of teacher appraisal that works off of a certain standard that is established by policy-makers as essential to effective teaching. An example is "The teacher will design coherent instruction."

Framework for Teaching: This standards-based teacher evaluation system was created by ETS. It has four domains: Planning and preparation, classroom environment, instruction, and professional responsibilities.

Pathwise: ETS's comprehensive teacher development program.

PRAXIS: A set of three tests for teacher competency required in many states to obtain a teaching certificate, credential, licensure. It has three parts, the PRAXIS I, which is a basic skills test; the PRAXIS II, which tests professional and content knowledge; and the PRAXIS III, which is classroom performance appraisal conducted by a trained assessor.

Correlation. Correlation is a measure of the relation between two or more variables. Correlation coefficients can range from -1.00 to +1.00 . The value of -1.00 represents a perfect negative correlation while a value of +1.00 represents a perfect positive correlation. A value of 0.00 represents a lack of correlation. (Statsoft, Inc, 2004) 


\section{CHAPTER I}

\section{INTRODUCTION}

More than any other time in the history of American teaching, professional educators are being asked to connect with learners in significant ways, to structure lessons with focused skill in order to consistently construct learning. A reliance on state tests and other high stakes assessments to manifest the achievement of standardized goals pressures teachers to maximize every moment in the classroom. Furthermore, administrators are tasked with supervising teachers in an evolving educational management/leadership role that demands more from them and from their schools. While their workloads continue to evolve into extremely complex leadership roles that involve much more than managing a school building and the teachers and learners therein, educational administrators find themselves unable to devote the time necessary to mold evaluation into the professionally enriching process that it is supposed to be.

An optimal evaluation system allows the principal and his assistants and department heads to become instructional leaders as they apply their education and experience in facilitative instructional leadership. In that leadership role, the principal has a potential to be an inspirational, visionary leader, a resource who can mentor new teachers to success. Actually, educators at every career level can profit from the principal who implements a powerful teacher evaluation process. In addition to mentoring new teachers, school administrators can aid mid-career teachers by pinpointing strengths and refocusing efforts. Principals can encourage the career educators as they press on in their professions. For all educators, evaluation can be a collegial dialogue in which growth areas are identified, mentoring proceeds, and teachers learn to update methods or content. 
Veteran teachers are usually storehouses of ideas just waiting to be tapped. By engaging in collegial conversations about education, the astute administrator can direct late career teachers into mentoring relationships with those who can glean from the wisdom of a seasoned educator. In this way, evaluation can be a guidance session toward professional development so that the entire school benefits from the evaluations of each teacher. Therefore, the teacher evaluation process contributes to school improvement.

But that is not the way evaluation has been. The traditional system of evaluation which involved one or two class observations followed by a brief conference in which the administrator and the teacher dutifully sign on a check-listed form has been recognized as a largely meaningless and time-consuming practice that does little to identify incompetent teachers or to improve the instructional quality of the school. (Danielson, 2001) For years, many teacher evaluations consisted of a mere checklist of unstandardized criteria by which the teacher was rated as either satisfactory or unsatisfactory. The brief observation was supposed to represent the teacher's work throughout the year, but in truth it offered little supervisory power or generalizability to the whole of the teacher's work. On a 180-day calendar, most teachers engage in instruction about 900 hours a year. With just one to two observation hours, the principal has observed between $0.1 \%$ and $0.2 \%$ of the teacher's work. ${ }^{1}$ Of previously employed systems, researchers found that "typical criteria are trivial, simplistic, and not relevant to what teachers should be doing in order to enhance student learning." that principals tended to view evaluation "as a means for accountability, teacher effectiveness, and improvement of curriculum. Only 7 of 39 principals (20.59\%) believed that the purpose of teacher evaluation was to improve student achievement and 
enhance student learning.,"3

Other problems exist in the traditional checklisted pass/fail teacher evaluation program. In the old system, no link between evaluation and individualized professional development emerged because very rarely did the evaluation reveal any unsatisfactory areas. The most the evaluation system could hope to do was to separate the lowest performing teachers from the average to good teachers based on fairly inconsistent standards. The simplistic parity of the teacher evaluation forms encouraged mediocrity from teachers and cursory supervision from principals. The evaluation was largely subjective, with the teacher being a passive participant, an observee who had little input into his or her evaluation beyond one or two brief meetings with the principal. Milanowski's description of the old system aptly fits: "The old system was cumbersome, its language outdated, and ... it placed little emphasis on instruction . . . the single annual observation used to assess most teachers was more of [a] check to ensure minimally acceptable performance than a formative process. ${ }^{4}$ Rubrics were rarely designed to identify the actual desired standards for good teaching, nor to detail what "unsatisfactory," "improvement needed," or "satisfactory" meant. The rubric became unnecessary if there was a simple checklist of competencies anyway. The beleaguered administrator was required to dedicate large amounts of time in observing, writing, and conferring on evaluations, and the whole time there was considerable doubt about the efficacy of the process in yielding better student achievement outcomes for the school. 


\section{APPLICATION}

After fifteen years of teaching in private Christian high schools, I was asked to return to a large Christian school in Florida as the new secondary assistant principal. Organizationally, the school had a president, a dean of academics (who was an instructional leader in the school), an elementary principal, a secondary principal, assistant principals in each division of the school, and a dean of students in each division. The school was a PreK-12 school with approximately 1300 students. Established in 1970 , the school had around 80 teachers, and turnover was decreasing due to increasing salaries. The school had an excellent reputation in the community as one of the best private schools in the county. The student population was in the upper $60 \%$ academically because new students were tested and the lowest $40 \%$ were denied admission. Therefore, until recently the school offered few exceptional education services but sports and fine arts were heavily emphasize. Mandatory chapels, Bible classes and Christian worldview training were the rule. With a lot of pressure to boost public opinion of the academics of the school, teachers were being charged on one hand to deliver more rigorous instruction, but on the other hand to remember that their students needed to feel good about school and to freely pursue their extracurricular interests.

Parents were largely supportive, they occasionally complained about aspects of the school culture that made some students unhappy. Negative feedback recurrently arose about the discipline system of the school, which was viewed as harsh and dehumanizing, though most parents did appreciate the safer environment and peaceful hallways. Another common complaint was that teachers demanded too much of students and if lower grades were given, parents seemed swift to complain to administration citing 
personality conflicts, unreasonable expectations, and teacher quality as the causes of lower grades rather than the disappointing academic work ethic on the part of the student. In this somewhat ambivalent and performance-based environment, I became part of the administrative team.

With salaries and student population increasing, more teachers were being hired. An effort to decrease class sizes and to increase advanced placement offerings, required more qualified teachers. Consequently, top management became more interested in identifying the best teachers and sorting those from the more mediocre and incompetent teachers, with which the secondary department had to deal occasionally. The president expressed dissatisfaction with the teacher evaluation checklist of teacher competencies that comprised the appraisal form that had been part of the administrative process for years. Twice each year, the teachers were observed, a pass/fail form was filled out with a list of identifying terms, and the teacher was asked to look over the list and sign. Peterson makes the following observation about the evaluation checklist:

Listings or what makes a teacher effective have been popular over the years in an attempt to reduce quality teaching to a usable catalog. Advocates have presented behaviors (Coker et al, 1980), competencies (Houston \& Howsam, 1972), characteristics (Stronge, 2002), standards (Ellet, 1997), duties (Scriven, 1988), or performance dimensions (Danielson, 1996; Heath \& Nelson, 1974) as complete descriptions of what is meant by good teaching. These listings are attractive to many educators because they promise a comfortable sense of coverage of what otherwise seems like a complex and shifting combination of components of complex human performance. However, the usefulness and comfort of these systems is illusory. The components of good teaching, however understood, are extensive (no complete list exists), not agreed on, context dependent, intermittently operant, and characteristic or applied by individual competencies or performance components. For example, one teacher is good as a taskmaster, whereas another fosters learning with a warm, supportive environment. ${ }^{5}$

Not only did the old list fail to adequately measure teacher quality, but rarely was the veteran educator offered any suggestion for growth. Even rarer was the mediocre or new teacher guided or mentored into excellence. The president and the board found all 
teachers -- except the most incompetent teachers -- making high marks in every area. $\mathrm{He}$ therefore tasked the secondary principal to create a better form that would give the teachers a score or that would show some sort of range.

The secondary principal assigned the task of developing a better evaluation system to me, his new assistant principal. Along with handling many other managerial tasks one would expect to be delegated to a junior administrator, I began researching various models of teacher evaluation. At first the research focused on locating a better "form" that would give the administration an improved checklist with perhaps more gradations of quality in each area. Several different models were found which at the core represented the same competencies, but in the margins differed widely depending on the philosophical bent of the authors.

One of the most thorough forms I found was part of the Pathwise program authored by Charlotte Danielson and published by ETS. Framework for Teacher presented four domains: Planning and Preparation, Classroom Environment, Instruction, and Professional Responsibilities. Each of these domains was further divided into components, and these were divided into elements. Our adaptation of these is available in Appendix A. Four graduated levels of performance were available for each element: Unsatisfactory, Basic, Professional, and Distinguished. The system was well-researched, professionally produced, and well-supported by ETS. Philosophically, student learning was the focus, not just teacher performance. The Pathwise program incorporated research-tested aspects of teaching and learning. Numerous manuals, forms, and training sessions were available. On further investigation, I found that some schools used their own adaptation of the Pathwise rubrics and forms, so I began adapting the system so it 
could be functional in our school using the school's unique job description as a guide. In implementing the Framework for Teaching, Odden points out that a fully functional standards-based teacher evaluation system requires the following:

1. A set of teaching standards that describes in considerable detail what teachers need to know and be able to do.

2. A set of procedures for collecting multiple forms of data on teacher's [sic] performance for each of the standards.

3. A related set of scoring rubrics that provide guidance to assessors or evaluators on how to score the various pieces of data to various performance levels and scheme to aggregate all microscores to an overall score for the teacher's instructional performance.

4. A way to use the performance evaluation results in a new knowledge-and skills-based salary schedule if the evaluation system is to be used to trigger fiscal incentives. ${ }^{6}$

However, after reading Danielson's books, I observed that only one and two of the above are recommended in her literature. The secondary administration was not interested in an aggregated numeric scale nor in proposing merit pay. I continued adapting rubrics and decided to propose the evaluation system to the administration. I then attended the Pathwise conference in Atlanta to receive specific training on how to conduct teacher observation, how to stage pre and post conferences, and how to use the huge number of evaluation system products and training ETS offered. After presenting my version of the standards-based teacher evaluation system to the principal and other administrators, they decided to adopt and further adapt the system to meet the needs of the school. The rubrics and other forms we drafted are included in the appendix of this thesis. Teachers and departmental leadership were asked to collaborate and to determine what the central goals of the system would be. The goals were as follows:

\section{Increasing Student Learning}

At the heart of every true teacher is the child that enters her classroom. As part of an historically underpaid workforce, many teachers feel called and motivated by altruistic goals, chiefly the well-being and learning of their students. Generally, teachers are most 
interested in their students' achievements, and anyone who listens to teachers talk will hear countless stories of "aha" moments, of what worked and what did not. Even if teachers complain about students, one can hear the loving heart of teacher. As education has evolved, the philosophy has shifted as teachers seek to optimize learning for all children, including those with special needs. Previously used evaluation systems have rarely focused on student learning because it is so hard to measure learning and to incorporate learning into teacher appraisal. Marshall writes: "Principals have little choice but to focus on teaching performance verses learning results, on chalkboard razzle-dazzle versus deep understanding, on beautiful bulletin boards versus demonstrated proficiency. Constrained by the supervision/evaluation process, principals over-manage the occasional lesson and undermanage the bigger picture of whether teachers are truly making a difference in student learning."7

Practically, and perhaps more mercenarily, everyone recognized at my school that with the school's tuition costs increasing and parents demanding a stronger academic program, the onus was on the administration to increase student achievement and to make sure that teachers were "truly making a difference in student learning." Some of the college entrance test scores revealed more average than above average achievement. In fact, it seemed that the SAT scores from year to year were actually decreasing as tuition costs and teacher salaries were rising. Some believed that parents had the right to expect more as they were paying more. Doubtlessly, parents were expressing the view that their tuition dollars should gain a better product, and that product included more than just state-of-the-art technology, a new campus, more sports, impressive fine arts, and better paid teachers. The students themselves should be achieving more and test scores should 
show higher levels of learning. More students, it was believed, should be qualified to attend better colleges.

The consensus was on point that though students were being taught in good facilities by experienced teachers, instruction was teacher-centered, and the evaluation system reflected that philosophy. Stake-holders were disinteresting in increasing academic rigor because many believed that students were already overworked. So the question became, "How can we get the students to learn more?" rather than just working more. The consensus was that the school needed to work smarter to educate the students more thoroughly. If teachers were using best practices, theoretically, the learners would retain and handle knowledge better, and the secondary school would see stronger outcomes without overloading the students with yet more work.

\section{Improving Instruction}

The test school in Florida had seen more than its share of excellent, memorable teachers, but some marginal teachers in the high school slid by in the evaluation process and continued their mediocrity year to year with impunity. Without a stronger system to support administrative supervision and intervention, the administration was limited in its effectiveness in intercepting marginal or incompetent teachers and to encourage average teachers to improve. The evaluation system heretofore employed just passed most teachers in all areas. To strengthen the proficient teachers and either develop or replace the mediocre ones, a more thorough, state-of-the-art evaluation process might be helpful. Also, the secondary school administration needed to identify and fire weak teachers who refused to improve.

\section{Developing Mentoring}


The school needed a better teacher induction program that outlined the expectation for new teachers and that promoted growth. If the school was to retain the best new teachers, some of whom were graduates with non-education majors, it needed to create an environment where teaching skills could grow with experience. With the goal of more AP classes, more liberal arts majors with high GPA's were needed to teach classes that required deep roots in the course content. The belief of the administration was that teaching skills could be taught on the job as long as the teacher was the right kind of Christian role model and that he was amenable to the training process. However, the mentoring program of the secondary school was not fully developed and consisted merely of a department head or senior teacher who would be available to assist the new teacher. Essentially, it was a "buddy system.” New teachers rarely found this mentoring relationship thorough enough to be truly helpful.

\section{Focusing Professional Development}

The school had a centralized professional development system in which a single administrator directed teachers to attend workshops to hear extended devotionals, Christian Worldview lectures, or general sessions on how to improve teaching. Additionally, yearly conventions offered some subject-specific sessions and some general sessions about Christian education. The widespread perception of the secondary faculty was that the expensive program was largely irrelevant. The consensus among the faculty was that a better program was needed. One idea was that through a more effective teacher evaluation system, teachers could self-select or be directed toward more individualized professional development. Subject-specific or grade-level specific professional development could replace attending homogeneous meetings that rarely 
applied to all teachers.

\section{Facilitating Collegiality}

The culture surrounding the teacher evaluation system at the test school was entirely summative, and teachers subsequently regarded the supervisory process as "my job is on the line." With more collegial relationships and more formative evaluations, teachers would feel free to dialogue with administrators about teaching, their subjects, and their students. Administrators, too, needed more collegiality and consensus on what quality teaching looked like, or perhaps just a better understanding of differing philosophies. A collaboratively created teacher evaluation system would create more effective, unified management.

\section{BIBLICAL WORLDVIEW INTEGRATION}

Effective Christian education requires (1) a powerfully articulated vision of what the school will produce in its graduates, (2) a bold and sustained commitment to a biblical mission, (3) wise selection of administration and instructional personnel who will carry out the promise of the vision and mission, and, (4) careful supervision of all parts of the school's program so that students, teachers, administration, and all the innumerable details work together harmoniously to testify of the excellence of the Christ. If the school's philosophy is to lead its students into growing discipleship in Christ, then that school must relentlessly determine that excellence is the only option in the fulfillment of that goal. In Gordon Brown's book Guiding Faculty to Excellence: Instructional Supervision in the Christian School (2002), an entire chapter is dedicated to the biblical foundations for supervision and they certainly apply in this study as it investigates teacher evaluation. Although his book applies to Christian schools specifically, these six 
principles are generally true for the Christian administrator who works in public education. The following are his six principles with my additional comments:

\section{Leadership -- The Principle of Authority and Order}

Administrators are responsible for taking the lead in schools and for maintaining an ordered culture. Someone has to be in charge to make sure there are order, vision, and guidance of the various complexities of school. The Bible is filled with examples of leaders who were responsible under God to direct and order the people of God.

\section{Service -- The Principle of Mutual Submission:}

The school must have a servant-leader at the helm of the institution. II Timothy 2:24 says that "The servant of the Lord must not strive, but be gentle unto all men, apt to teach, patient." Evaluating and supervising are critical services to the teacher, the parents, and the students. The teachers need experienced guidance and thoughtful constructive feedback from the instructional leader in the school if they are to be effective, just as the administrator depends on the teachers and his fellow administrators to serve him in this capacity.

\section{Mission -- The Principle of Unity of Purpose:}

This biblical principle applies to all schools that can drift in their mission unless a watchful administrator keeps the institution anchored to its purpose. Jesus prayed specifically in John 17 for the unity of His disciples: "I pray ... that they may be one; as thou, Father, art in me, and I in thee, that they may be one in us: that the world may believe that thou has sent me." It is critical if Christian school ministry is to reach the world, that all the members of the ministry be focused on the Christian mission of teaching making disciples, and through instructional leadership and supervision, the 
administrator can keep the school on target with its mission.

\section{Love -- The Principles of Relationships}

Discretely evaluating the teacher and giving loving and truthful feedback honors the teacher and strengthens the relationships in the school. Ephesians 4:15 encourages that believer not to be swayed by the varied doctrines and theories $d u$ jour, but to "speak the truth in love." Those who evaluate must keep this verse foremost in their minds as they deal with their teachers, for the truth can be spoken without wounding the teacher when improvement is the consistent goal. I John 4:18 says that there is "no fear in love, but perfect love casts out fear." Evaluating honestly takes courage, but it is an expression of love toward a teacher and is a critical function of the supervisory relationship.

\section{Excellence - The Principle of Continuous Improvement}

This biblical concept flows from Ephesians 4:12 and Philippians 3:14. Just as Paul pressed toward the mark of his high calling, administrators should lead their faculties in pressing toward excellence as educators. Just as students can maximize their gifted potential as they submit to the will of Christ, the faculty can as well. The administrator takes on an important role in leading his teachers toward honing their spiritual gift of teaching.

\section{Stewardship -- The Principle of Maximum Personnel Utilization}

Schools are filled with teachers that have God-given gifts. As stewards of these human resources, the Christian administrator is accountable to the school's stake-holders not the squander these invaluable resources. Therefore, God clearly expects administrators to maximize student and teacher potential. Supervision and effective evaluation are indispensable in biblical school management. ${ }^{9}$ 


\title{
STATEMENT OF PROBLEM/RESEARCH QUESTIONS
}

After implementing the modified Pathwise teacher evaluation system at the school in

Florida, and reading some of the statistical correlation studies of Milanowski, Heneman, and others, I was interested in determining if the student achievement gains were higher when the students were taught by teachers with higher evaluation scores. Regarding correlation between evaluation score and student achievement gains, Odden writes the following of standards-based teacher evaluation:

\begin{abstract}
The first major lesson learned [about standards-based teacher evaluation] is that districts and schools can design and implement ambitious, performance-based teacher evaluation systems that have a substantial degree of criterion-validity .... In both Cincinnati, and the Vaughn charter school [in Los Angeles, CA], where the results are or were intended to linked to pay increases, there were strong linkages between teacher evaluation scores and student learning gains; similar but somewhat weaker and more sporadic linkages were found for the program in Washoe County [Nevada]. In Cincinnati and Vaughn, the Bayes residual correlations-ranging from 0.30 and 0.40 -were comparable to those found in the research on the criterion validity of performance evaluation in the private sector and much higher than commonly found in education. The results have shown on average that teachers with higher evaluation scores produced more student learning gains than predicted based on prior test scores and demographic characteristics for the student in their classrooms than did other teachers with lower evaluation scores. Given that teachers were scored at four different levels of performance, the results show that average student learning gains in each higher level or performance was greater than the previous and that the top-rated teachers-at the accomplished or distinguished levels-produced the most learning gains. ${ }^{10}$
\end{abstract}

As the test school began using the standards-based teacher evaluation system, replication of the statistical multi-linear regression process was proposed for this project. However, due to confidentiality issues and a job change from that school I was unable to obtain permission for the study. The tests were not true pre-post either, so that achievement gains were not measured properly to correlate one year's growth to a teacher's evaluation score for that year. Additionally, I was the only individual conducting the actual evaluations, so inter-rater reliability would be impossible.

The purpose of the research presented here is generally to determine the perception of faculty of how well teacher evaluation systems improve schools, and specifically to find 
the teacher perception of how well the standards-based teacher evaluation system of the test school met goals that the faculty committee and administrators established. It is important to consider the faculty's perceptions of the evaluation system and their opinion of instructional leadership in their building. Connected to instructional supervision is the yearly evaluation process, for as many have noted, the evaluation process allows the principal to lead his faculty through formative processes and also gives him a basis for personnel decisions (Danielson, 1996). An important step in implementing a new evaluation system is surveying the faculty to find out the level of their commitment to teaching and learning. After implementing the teacher evaluation system, there were still further questions about how the faculty perceives the evaluation process, and if they view supervision as valuable, tolerable, deplorable, or a necessary evil. The degree to which teachers are teachable, the confidence they hold in the administration, and the opinions they hold of the school or district evaluation program should at least inform or perhaps influence teacher evaluation system decisions.

\section{Therefore, the research questions of this thesis are as follows:}

1. Do teachers generally believe that teacher evaluation relates to teaching and learning?

2. Do teachers generally believe that professional development is needed or helpful to professional educators?

3. Did the implemented standards-based teacher evaluation in the test school achieve the five goals previously noted? (increasing student learning, improving instruction, developing mentoring, focusing professional development, facilitating collegiality) 4. Is there a difference between the teachers' perceptions of teacher evaluation in the general population compared to the perceptions of teachers in the subject school three 
years after the system was implemented?

5. Are efforts to link teacher evaluation and professional development improving teacher perceptions of teacher evaluation and professional development programs?

\section{Hypotheses and null hypotheses to these questions are as follows:}

1. Teachers believe that teacher evaluation affects teaching and learning in their schools. $\varnothing=$ Teachers have no belief that teacher evaluation affects teaching and learning in schools.

2. Teachers believe that their school's professional development program affects teaching and learning in their schools.

$\varnothing=$ Teachers have no belief that their school's professional development program affects teaching and learning in their schools.

3. Teachers perceive that the use of the standards-based teacher evaluation system achieved the goals of improving student learning, instruction, mentoring, professional development, and collegiality.

$\varnothing=$ Teachers do not perceive that use of the standards-based teacher evaluation system achieved the goals of improving student learning, instruction, mentoring, professional development, and collegiality.

4. There is a statistically significant difference between the teachers' perceptions of teacher evaluation in the subject school the perceptions of the control group. $\varnothing=$ There is no statistically significant difference between teacher perceptions of the effectiveness of teacher evaluation systems in the subject school and the general sample. 5. Linking teacher evaluation systems with professional development programs increases teachers' perceptions of the value of both programs. 
$\varnothing=$ Linking teacher evaluation systems with professional development programs does not increase teachers' perceptions of the value of these programs.

\section{EDUCATIONAL SIGNIFICANCE}

In this era of increased accountability, evaluation is becoming more and more important as an administrative function. If the processes of teacher evaluation and professional development are to be worth the time invested, school leadership must be sure that there is consensus among the faculty regarding the value of these time consuming and sometimes expensive functions. Only when teachers respect the process of evaluation and find value in professional development efforts and when these programs are linked will they achieve the ultimate goal of actually increasing student learning. Then teacher evaluation and professional development will become more productive and less ritualized and these programs will catalyze school improvement. 


\section{CHAPTER II}

\section{LITERATURE REVIEW}

Literature on the subject of teacher evaluation abounds. With the passing of NCLB much more has been published in the last 10 years as districts make sweeping changes to their evaluation policies. For this study, I collected research from four interrelated categories:

\section{A. Informational Resources For Teacher Evaluators}

Several textbooks and handbooks (Stronge and Tucker, 2003; Whaley, et al., 2002; Campbell, 2004) are available that are designed to support educational leadership coursework and therefore contain comprehensive introductions to teacher evaluation. These texts detail how districts conduct the teacher evaluation process. Probably the most recent text book on teacher evaluation and supervision is the Nolan (2007) text which presents not just instructions on how to evaluate and supervision, but also the political, emotional, and social issues that are created in school environments. The text also presents many of the studies recently conducted on teacher evaluation. One study

(Kersten, T and Israel, M., 2005) demonstrated through a survey of principals that more thorough evaluation systems, though appreciated for there scope, are largely impossible to wield as part of the already over-extended task list of the typical school administrator. Other sources specifically update new directions in educational evaluation (Stronge, 1997) or describe regional teacher evaluation system initiatives (Barnett, 2002; Mo, et al, 1998; Takakara and Ono, 2001). There were several case studies of how certain model evaluation systems work (David, 2002; Kimball, 2001; Snyder, 2001). One article specifically details how web-based technology can support an elaborate system in a large 
district (Ellett, 2002). Others make certain important critical observations (Soar, et al, 1983) about the issues and personnel problems such as the famous "halo effect" (Buck and Tiene, 1989) or recommend ways of combating the one-size-fits-all appraisal tendency (Cruickshank and Haefele, 2001). A couple of resources not only point out that teacher evaluation practices must be reformed so that the evaluation accomplishes its purposes of professional development and quality assurance (Danielson, 2000, 2001; Marshall, 2005), but then detail a standards-bases program called “A Framework for Teaching" (Danielson, 1996; Danielson and Egelson, 2000). Danielson (2005) and others (Egelson, et al, 1998; McColskey and Egelson, 1997) wrote works that explain the obvious, powerful, but largely unused link between evaluation and individualized professional growth. Kimball, Milanowski, and Heneman (2007) followed up on previous studies to explain the varied structures, overall effectiveness, teacher perceptions, and correlations between standards-based teacher evaluation and student achievement scores.

Like Danielson and others who write on standards-based teacher evaluation, some of the articles in this category make very specific recommendations. Articles in the literature recommend self-directed evaluation (Donaldson, 2000), multiple exchange evaluation (Dyer, 2001), portfolio appraisal (Painter, 2001; St. Maurice, 2004; Tucker, et al, 2002), and multiple data source evaluation (Peterson, et al, 2001). Quality feedback is addressed in Feeney (2007). Still other articles generally advise (Pool, 2001) or remind the administrator on how he or she can evaluate veterans (Howard, 2001) and interns (McGee and Imbeau, 2001). Books and articles present issues (Fischer, et al, 2003) related to evaluating mathematics educators (Lester, 2001), music educators (Maranzano, 
2000), and special educators (Nougaret, et al, 2005; Blanton, 2007).

A unique and powerful resource for the Christian school administrator is Brown's (2002) text Guiding faculty to excellence: Instructional supervision in the Christian school. This text contains a rational, thoroughly Christian perspective on faculty supervision and evaluation. A familiar theme form accrediting agencies that require school improvement plans emerges as Dr. Brown suggests that all teachers should be working toward improvement, and that real supervision is to assist each faculty member with that goal. Brown's book is a very important text for developing a process of meaningful supervision and evaluation that will retain teachers, develop faculty, and ensure that Christian (not corporate) ethics are followed in administrating a Christian school.

A recent article by Reddehopp (2007) links the teacher appraisal process to the school improvement plan. As principals must devote considerable time to both evaluations and to accreditation processes, they should find ways to link them. The article suggests that faculty should create their own personal professional and instructional goals relative to the institutional goals as outlined in the school improvement plan, and then they can conduct self-evaluation and be externally appraised based on those goals. In this way, the emphasis is placed on the formative phase of teacher evaluation, which is more in line with the philosophy of continuous school improvement. Another key suggestion in this article is the formation of quality teams. Each of five administrators takes one fifth of the teachers and has a monthly meeting to determine where quality needs to be shored up and how to implement the school improvement plan. In terms of teacher quality, the quality head becomes the mentor and facilitator of improvement for the teachers and time is 
redirected from formal summative evaluation to formative evaluation in an environment which focuses on teacher improvement, retention, and collegiality. Nathan (2005) also made several recommendations on how to use teacher evaluation to inform professional development decisions.

\section{B. Resources That Report Political Issues in Teacher Evaluation}

Like all aspects of education, teacher evaluation is political. Supported by research on teacher/classroom effects, policy-makers have now suggested that to improve American public schools, teachers must be forced to improve or leave the field (Castor, 2002; Grover and Bernstein, 2005). Sources include news reports (Keller, 2004; Johnston, 1999) and issue briefs (Goldrick, 2002) that demonstrate how schools need to reform teacher evaluation. One hot issue relative to teacher evaluation is merit pay. Censuring or rewarding based on test scores (Millman, 1997) and using test scores for evaluation (Tucker and Stronge, 2001) have become important issues in the marketplace of ideas. One published (Reid, 2002) report says that evidence is emerging that merit pay works in increasing student achievement, and the district plan to further award cash to teachers. Other sources (Hill, 2000) discuss value-added scoring and the impact of this form of teacher evaluation on contracts and bargaining units. The debate over merit pay (McCollum, 2001; Ramirez, 2001) continues.

Another less publicized political issue that relates to teacher evaluation is the issue of how to implement a new teacher evaluation system without creating a political problem in the district or the school. Stronge and Tucker (1999) have conducted case studies that yield recommendations on how to effectively implement standards-based teacher evaluation systems. Additionally, Peterson (2002) has recommended peer review as part 
of a larger evaluation process, while others have called for consideration of ethical and political problems that these processes can create. Heneman et al (2006) examined the emerging trend in some states to award skill-based pay to teachers who do well on performance appraisals in schools that have standards-based teacher evaluations.

"Though slow to take hold, this incentive strategy is currently being pursued in several states." These findings echo those of Odden $(2004,127)$ who writes that educators have found ways to ensure validity and reliability while using standards-based teacher evaluation systems and that these are being used to "trigger pay increases."

\section{Resources About the Psychology and Sociology of Teacher Evaluation}

Since teacher evaluation involves groups of people and human behavior, there are some resources that examine the psychology and sociology of teacher evaluation. Most of the research focuses on the teachers' (Bastarche and Arthur, 2000; Milanowski and Heneman, 2001; Rapp, 2003; Sweeley, 2004, Henemen and Milanowski, 2003) and principals' (Loucks and Barker, 2000) perceptions of teacher evaluation systems and perceptions of administrators who conduct the appraisals (Chow, et al, 2001; Chow, et al, 2002; Zimmerman and Deckert, 2004). Milanowski (2005) examined the supposed problem of the principal's split role of evaluator and mentor to conclude that there is little impact with one supervisor filling both roles.

Kimball (2002) investigated the perceptions of feedback, enabling, and fairness as standards-based teacher evaluation is implemented. Since Danielson's Framework for Teaching is differentiated for career stages, King and Marie (2003) researched perceptions of that process. The most recent research includes Conley (2006), who studied career satisfaction among teachers who were evaluated with standards-based 
evaluations; Turpin (2005), who found that teacher evaluation positively affected the teachers' attitude toward their jobs; Bouchama (2006) who surveyed over 300 teachers in Canada to find that Canadian teachers prefer to be evaluated by their principals; and Schumacher (2006). Schumacher's study relates closely to the research question of this thesis. He surveyed and interviewed teachers in a Wisconsin district that had implemented a standards-based evaluation system on the bases of expectancy, instrumentality, and valence. Expectancy was the belief that they could measure up to the standards. Instrumentality was the measure that students would learn more, and valence was the value of the outcomes. Expectancy was high, instrumentality was low, and valence was low, so the program was scrapped. Further research into teacher satisfaction (Conley, 2005) revealed mixed opinions and levels of satisfaction when standards-based teacher evaluation was implemented due to "role ambiguity and work criteria autonomy."

\section{Resources That Relate Teacher Evaluation and Student Achievement}

Black (2004) has suggested that teachers can use certain techniques to engage disconnected students to increase their achievement, and since that is an important component of the Framework for Teaching, it becomes important in this study. Several dissertations have been written relating teacher evaluation and student achievement, including Smith and Henrique (1993), Bourff and Blane (1994), Murphy (1993), and Hutto and Dean (2001), and Schumacher (2004) and Xu (2001). Several articles demonstrate the importance of relating student achievement to teacher appraisal. Coker (1985) and Medley and Coker (1987) found that principal's rating correlated very weakly with student achievement test scores. However, several research studies indicate that the 
Framework for Teaching model produces low to medium level correlations (Gallagher, 2004; Kimball, et al, 2004; Milanowski, 2004; Olina and Sullivan, 2004) using the Bayes correlational formua and multi-linear regression formulas that control of numerous factors such as class size, SES status, career stage, race, etc . Researchers like DarlingHammond (1997) and Lee (2002) are calling for standardized systems and others (Lydia, 1984; Xu, 2002; Stronge and Tucker, 2000) believe the work of connecting student learning and teacher evaluation will aid in accomplishing the goal of equipping students for optimal achievement (Lee, 2002).

In the last two to three years, more researchers, especially from the University of Wisconsin Madison and the University of Southern California have investigated the corelationship of student achievement and teacher evaluation. The following doctoral candidates formed a cohort to inductively study high performing, low SES schools in Southern California. Common traits of the schools were visionary leadership, collaboration, and high expectations. Alleman (2006), Landsman (2006), Miranda (2006) and Paik (2006) found little or no evidence that the schools' success could be attributed to the teacher evaluation program of the school. Turpin (2005) and Norheim (2006) found in their schools that teachers perceived that teacher evaluation process did positively affect the school, either in teaching or learning, or both.

One system that drew attention was the Tennessee Valued-Added Assessment System (TVAAS) and some articles reference the statistical formulas, political impact, and opinions are raised surrounding the merit pay aspects of the system. (Hill, 2000; Bracey, 2004; Ballou, 2004; Kupermintz, 2001)

Two researchers (Gallagher, 2004, and Kellor, 2005) provided more insight into the 
frequently studied Vaughn Elementary Charter School in urban Los Angeles finding that teacher evaluation and merit pay programs did impact learning significantly, providing further anecdotal reinforcement of previous multi-linear regression studies that showed co-relationship between evaluation scores and high-stakes test scores at Vaughn. Archibald (2007) replicated the statistical studies of Malinowski (2004) and Kimball (2004) in a Wisconsin district that used standards-based teacher evaluation to find small to medium correlations between evaluation scores and student scores. 


\section{CHAPTER III}

\section{METHODS}

A survey was created to measure teacher perceptions of evaluation and professional development. The survey included seven demographic questions and twenty Likertscale closed-response questions with five possible choices for each question. Before gathering respondents to the survey, the survey was checked over by the education department chair at Cedarville, and a small test group was consulted. Permissions were gathered from several public and private schools in the Southeast. Eighty-seven random teachers responded to the survey. Teachers seemed to find value in the survey and testified that it took about ten minutes to complete. Of these eighty-seven teachers, twenty-one were from the test school where the standards-based teacher evaluation system had been implemented three years ago. Group A is the control group comprised of 66 random teachers from the Southeast. Group B is the test group with 21 participants from the test school. Group AB is the combination of groups A and B with 87 participants.

\section{STATISTICAL ANALYSIS}

Similar to the Mo (1998) and Chow (2002), the survey was administered to a random sampling of teachers from a specific geographical region, the Southeast US. The survey contained twenty questions in a Likert-scale response style to measure teacher perceptions of evaluation and professional development programs in schools. After the surveys were completed, the demographic results were loaded onto Microsoft Excel as were the results from the Likert-style questions. The results from the school with standards-based teacher evaluation were combined and separated from the rest of the data 
so that comparisons and correlations could be drawn. So that central tendencies could be calculated, the Likert-style questions were given mathematical values as follows:

Table 3.1 Mathematical Equivalents of Likert-Scale Responses

\begin{tabular}{lc} 
Response & Mathematical Equivalent \\
\hline Strongly Disagree & -2 \\
Disagree & -1 \\
Neither Agree Nor Disagree & 0 \\
Agree & +1 \\
Strongly Agree & +2
\end{tabular}

Results from each of the questions were graphed, and means were analyzed.

Interpretations, proposed findings, and recommendations are presented. 


\section{CHAPTER IV}

\section{RESULTS}

\section{Demographics}

The following are the results of the seven demographic questions on my survey. Fifteen of the respondents $(17 \%)$ were male teachers and $72(83 \%)$ were female. Seven identified themselves as part-time teachers with 80 checking full-time. In terms of career stages the results are on table 4.1.

Table 4.1. Career Stages of Survey Respondents (Group AB / $n=87$ )

\begin{tabular}{lcc}
\hline Length of Career & No. of Teachers & Percentage \\
\hline <1 Years & 4 & $1.0 \%$ \\
2-4 Years & 17 & $19.5 \%$ \\
5-10 Years & 27 & $31 \%$ \\
11-20 Years & 23 & $26.4 \%$ \\
21+ Years & 16 & $18.3 \%$ \\
Total: & 87 & \\
\hline
\end{tabular}

The majority of teachers were in professional stages of their careers with only $20 \%$ considered new to the profession ( $<5$ years). Of the respondents, 36 teach in public schools, 6 teach in non-sectarian private schools, and 46 teach in Christian schools. The schools in which the teachers are employed teach the following grade levels: 65 teachers are in buildings that teach all grades, three are in secondary schools, and 20 are in elementary schools. Of the respondents, 45 teach elementary grades and 48 teach secondary students. The number is over the sample size of 87 because teachers checked more than one level. Educational attainment of the respondents is shown on table 4.2. 40 Teachers were state certified and smaller numbers were certified by non-government agencies. 24 were certified by ACSI, and 3 were certified by an independent school association. 22 of the responding teachers were uncertified. 
Table 4.2. Educational Attainment of Survey Respondents (Group AB / $n=87$ )

\begin{tabular}{lcc}
\hline Educational Level & Number of Teachers & Percentage \\
\hline Bachelor's Non-Teacher Ed. & 10 & $11.6 \%$ \\
Bachelor's in Teacher Education & 25 & $29 \%$ \\
Graduate Courses in Education / & 10 & $8.6 \%$ \\
Incomplete Master's & & \\
Master's Degree / Non-Education & 7 & $8.1 \%$ \\
Master's Degree / Education & 27 & $31.3 \%$ \\
No Response & 9 & $9.3 \%$ \\
Total: & 87 & \\
\hline
\end{tabular}

Question 1. As a beginning teacher, I felt/feel I was prepared through my undergraduate

training to enter the field of education. The results from this question are in Table 4.3.

Table 4.3. Question 1: As a beginning teacher, I felt / feel I was prepared through my undergraduate training to enter the field of education.

\begin{tabular}{|c|c|c|c|c|c|c|c|}
\hline Response & $\begin{array}{c}\text { Group } A B \\
\text { Teachers }\end{array}$ & $\%$ & $\begin{array}{c}\text { Subgroup } \\
\text { A: } \\
\text { Non-Test } \\
\text { School } \\
\text { Teachers }\end{array}$ & $\%$ & $\begin{array}{c}\text { Subgroup } \\
\text { B: } \\
\text { Test } \\
\text { School } \\
\text { Teachers }\end{array}$ & $\%$ & $\begin{array}{c}\text { Difference: } \\
\text { Subgroup A\%- } \\
\text { Subgroup B\% }\end{array}$ \\
\hline $\begin{array}{l}\text { Strongly } \\
\text { Agree }\end{array}$ & 18 & $21 \%$ & 16 & $24 \%$ & 3 & $14 \%$ & $-10 \%$ \\
\hline Agree & 40 & $46 \%$ & 31 & $47 \%$ & 9 & $43 \%$ & $-4 \%$ \\
\hline $\begin{array}{l}\text { Neither } \\
\text { Agree Nor } \\
\text { Disagree }\end{array}$ & 14 & $16 \%$ & 9 & $14 \%$ & 4 & $19 \%$ & $+5 \%$ \\
\hline Disagree & 9 & $10 \%$ & 6 & $9 \%$ & 3 & $14 \%$ & $+5 \%$ \\
\hline $\begin{array}{l}\text { Strongly } \\
\text { Disagree }\end{array}$ & 6 & $7 \%$ & 4 & $6 \%$ & 2 & $1 \%$ & $-5 \%$ \\
\hline No Response & 0 & & & & & & \\
\hline Total: & 87 & & 66 & & 21 & & \\
\hline
\end{tabular}

Of the respondents in group $\mathrm{AB}$, almost two-thirds responded positively to the question.

The remainder $(33.1 \%)$ did not agree with the statement that they were prepared through their undergraduate training to become teachers. Of group A (non-test school teachers), the positive responses were very similar to group $\mathrm{AB}$. The test school had a smaller number respond that they felt prepared to enter their jobs through their undergraduate studies $(58.1 \%)$. Central tendency of these responses is on Table 4.4. 


\begin{tabular}{lccc}
\hline Measures & Group AB & $\begin{array}{c}\text { Subgroup A: } \\
\text { Non-Test School } \\
\text { Teachers }\end{array}$ & $\begin{array}{c}\text { Sub-Group B: } \\
\text { Test School Teachers }\end{array}$ \\
\hline Mean & .65517 & .74627 & .06943 \\
Median & 1 & 1 & 1 \\
Mode & 1 & 1 & 1 \\
\hline
\end{tabular}

The mean of the target respondent group was nearly midway between neither agree nor disagree and agree, indicating that a majority of teachers in the respondent group felt prepared for teaching. The mean of sub-group B (the test school teachers) had a lower mean, indicating a lack of confidence in their preparation for teaching.

\section{Discussion}

The general confidence of the sample in their preparation for teaching suggests that teacher education is generally having an impact on the self-efficacy of teachers as they enter the classroom. The test school seems to have more teachers who lack this confidence, but this may be because that school tends to hire non-education majors and teachers who are not state certified. In subgroup B, 38\% of the respondent teachers had education degrees. In sub-group A, $62 \%$ had degrees in education. The two goals that were suggested by the committee on teacher evaluation and professional development are consistent with the results of the survey. Teachers at the test school may need more mentoring and specifically targeted professional development than in other schools since the school tends to hire liberal arts majors and then expects them to learn teaching skills on the job. By building teaching skills among the faculty, it seems plausible that student learning could increase. 
Question 2: Our school/district has an effective teacher induction / mentoring program to support new teachers. Results are listed in Table 4.5:

Table 4.5. Question 2: Our school/district has an effective teacher induction / mentoring program to support new teachers.

\begin{tabular}{|c|c|c|c|c|c|c|c|}
\hline Response & $\begin{array}{l}\text { Group AB: } \\
\text { Number } \\
\text { of Teachers }\end{array}$ & $\%$ & $\begin{array}{c}\text { Subgroup } \\
\text { A: } \\
\text { Non-Test } \\
\text { School } \\
\text { Teachers } \\
\end{array}$ & $\%$ & $\begin{array}{c}\text { Subgroup } \\
\text { B: } \\
\text { Test } \\
\text { School } \\
\text { Teachers } \\
\end{array}$ & $\%$ & $\begin{array}{c}\text { Difference } \\
\text { Subgroup A- } \\
\text { Subgroup B }\end{array}$ \\
\hline $\begin{array}{l}\text { Strongly } \\
\text { Agree }\end{array}$ & 12 & $14 \%$ & 11 & $17 \%$ & 2 & $1 \%$ & $-16 \%$ \\
\hline Agree & 37 & $43 \%$ & 29 & $44 \%$ & 9 & $43 \%$ & $-2 \%$ \\
\hline $\begin{array}{l}\text { Neither } \\
\text { Agree Nor } \\
\text { Disagree }\end{array}$ & 22 & $26 \%$ & 15 & $23 \%$ & 6 & $29 \%$ & $+6 \%$ \\
\hline Disagree & 12 & $14 \%$ & 9 & $14 \%$ & 3 & $14 \%$ & $-6 \%$ \\
\hline $\begin{array}{l}\text { Strongly } \\
\text { Disagree }\end{array}$ & 4 & $5 \%$ & 3 & $5 \%$ & 1 & $5 \%$ & 0 \\
\hline No Response & 0 & & & & & & \\
\hline Total: & 87 & & 66 & & 21 & & \\
\hline
\end{tabular}

Positive responses for the group $\mathrm{AB}$ were represented $56 \%$ of respondents, while positive responses were fewer in subgroup B (43.9\%) than in subgroup A (60.7\%) Negative or neither positive or negative responses were given $44 \%$ of the time by the group $\mathrm{AB}$, but higher in subgroup B and in subgroup A. The most significant difference was in the strongly agree response, with $15.7 \%$ more in subgroup A than in subgroup B.

Table 4.4 shows the central tendency of these results:

Table 4.4. Central Tendency Question 2:

\begin{tabular}{l|c|c|c}
\hline \multicolumn{1}{c|}{ Measures } & Group AB & $\begin{array}{c}\text { Subgroup A: Non- } \\
\text { Test School } \\
\text { Teachers }\end{array}$ & $\begin{array}{c}\text { Sub-Group B:Test } \\
\text { School Teachers }\end{array}$ \\
\hline Mean & .4827 & .5373 & .3 \\
Median & 1 & 1 & .5 \\
Mode & 1 & 1 & 1 \\
\hline
\end{tabular}

These means indicate that while most teachers answer in agreement with the survey item, the consensus places the general response nearer to zero for both group $\mathrm{AB}$ and for subgroup B. Figure 4.1 shows that while most respondents in all three groups choose to agree, more in group A strongly agreed and more in group B responded neutrally to the 
question of the quality of new teacher mentoring in their schools.

Figure 4.1 Comparison of Responses to Question 2

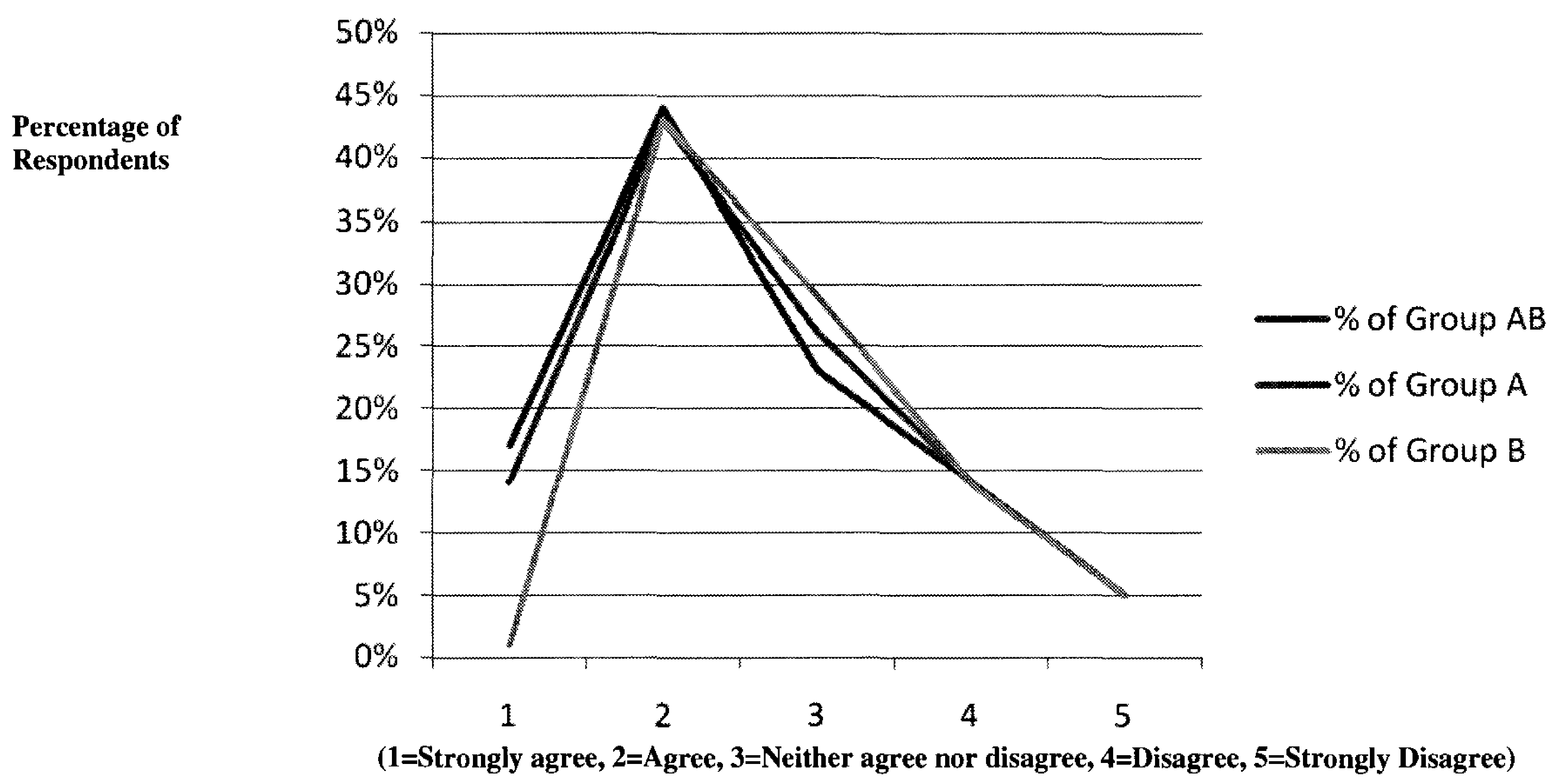

\section{Discussion}

The presence of teacher induction and mentoring programs is very important as schools try to retain first and second-year teachers. The Pathwise products included teacher induction materials linked to the four domains of the ETS program, but other such onthe-job training programs provide important support for new teachers. With numerous non-education majors employed at the test school, it is vitally important to have more than a marginal induction program in place so that teachers and students can benefit from teachers who are getting assistance in honing their craft. These data suggest that the goals of improving mentoring and professional development at the test school are still not successful in the eyes of the faculty. 
Question 3: The administration in my school evaluates teachers with good frequency.

The results of the survey are in table 4.5 .

Table 4.5. Question 3: The administration in my school evaluates teachers with good frequency.

\begin{tabular}{|c|c|c|c|c|c|c|c|}
\hline Response & $\begin{array}{l}\text { Group AB: } \\
\text { Number of } \\
\text { Teachers }\end{array}$ & $\%$ & $\begin{array}{l}\text { Subgroup } \\
\text { A: } \\
\text { Non-Test } \\
\text { School } \\
\text { Teachers }\end{array}$ & $\%$ & $\begin{array}{c}\text { Subgroup } \\
\text { B: } \\
\text { Test } \\
\text { School } \\
\text { Teachers }\end{array}$ & $\%$ & $\begin{array}{l}\text { Difference } \\
\text { Subgroup A- } \\
\text { Subgroup B }\end{array}$ \\
\hline $\begin{array}{l}\text { Strongly } \\
\text { Agree }\end{array}$ & 22 & $25 \%$ & 18 & $27 \%$ & 4 & $19 \%$ & $-8 \%$ \\
\hline Agree & 48 & $55 \%$ & 35 & $53 \%$ & 13 & $62 \%$ & $+9 \%$ \\
\hline $\begin{array}{l}\text { Neither } \\
\text { Agree Nor } \\
\text { Disagree }\end{array}$ & 7 & $8 \%$ & 5 & $7 \%$ & 2 & $10 \%$ & $+3 \%$ \\
\hline Disagree & $\overline{10}$ & $11 \%$ & 8 & $21 \%$ & 2 & $10 \%$ & $-11 \%$ \\
\hline $\begin{array}{l}\text { Strongly } \\
\text { Disagree }\end{array}$ & 0 & & 0 & & 0 & & \\
\hline No Response & & & & & & & \\
\hline Total: & $\overline{87}$ & & $\overline{66}$ & & 21 & & \\
\hline
\end{tabular}

The above results indicate that teachers are quite confident that administrators are evaluating them with good frequency. Over $80 \%$ responded with agreement, suggesting that the trend of observing and supervising teachers only once or twice yearly for a few minutes in each episode is no longer the norm. In the past, teachers in the test school would only rarely see their administrator in the classroom, so the trend seems to be established to observe more frequently. The central tendency is shown in Table 4.6.

Table 4.6. Central Tendency Question 3:

\begin{tabular}{|c|c|c|c|}
\hline Measures & Group $A B$ & $\begin{array}{c}\text { bgroup A: } N \\
\text { Test School } \\
\text { Teachers }\end{array}$ & $\begin{array}{l}\text { Sub-Group B:Tes } \\
\text { School Teachers }\end{array}$ \\
\hline Mean & .931 & .94 & .9 \\
\hline Median & 1 & 1 & 1 \\
\hline Mode & 1 & 1 & 1 \\
\hline
\end{tabular}

Question three ties in with the first two goals of the teacher evaluation system as agreed upon by the evaluation system committee. Instruction and learning will always be enhanced as teachers step up their practice and as they are encouraged by the visible administrator. The results of this survey question bring encouraging news. Instruction 
supervision is underway at the test school and revised teacher evaluation program is working in terms of frequently getting administrators in every classroom.

Question 4: I wish that lead teachers or department heads would observe my classroom more. This question was taken almost verbatim from a Hong Kong survey done in the nineties. ${ }^{1}$ Mo found that teachers believed they would improve their practice if they were observed more, and that they desired to improve practice, yet, given this question and question 7, they preferred not to be observed. However, given the choice, teachers preferred the principal over the department head, even though they knew the department head would be able to help them improve instruction. The study also indicated the famous "Halo Effect." Principals tend to overrate and under-criticize for numerous reasons. The results (Table 4.7) from this question are similar to Mo's.

Table 4.7. Question 4: I wish that lead teachers or department heads would observe my classroom more.

\begin{tabular}{|c|c|c|c|c|c|c|c|}
\hline Response & $\begin{array}{c}\text { Group AB: } \\
\text { Number } \\
\text { of Teachers }\end{array}$ & $\%$ & $\begin{array}{c}\text { Subgroup } \\
\text { A: } \\
\text { Non-Test } \\
\text { School } \\
\text { Teachers }\end{array}$ & $\%$ & $\begin{array}{c}\text { Subgroup } \\
\text { B: } \\
\text { Test } \\
\text { School } \\
\text { Teachers }\end{array}$ & $\%$ & $\begin{array}{c}\text { Difference } \\
\text { Subgroup A- } \\
\text { Subgroup B }\end{array}$ \\
\hline $\begin{array}{l}\text { Strongly } \\
\text { Agree }\end{array}$ & 2 & $2 \%$ & 2 & $3 \%$ & 0 & & $+2 \%$ \\
\hline Agree & 11 & $13 \%$ & 7 & $11 \%$ & 4 & $19 \%$ & $-7 \%$ \\
\hline $\begin{array}{l}\text { Neither } \\
\text { Agree Nor } \\
\text { Disagree }\end{array}$ & 39 & $45 \%$ & 30 & $45 \%$ & 9 & $43 \%$ & $+2 \%$ \\
\hline Disagree & 31 & $36 \%$ & 24 & $36 \%$ & 7 & $33 \%$ & $+3 \%$ \\
\hline $\begin{array}{l}\text { Strongly } \\
\text { Disagree }\end{array}$ & 4 & $5 \%$ & 4 & $6 \%$ & 0 & $0 \%$ & $+6 \%$ \\
\hline No Response & $\overline{0}$ & & 0 & & $\overline{0}$ & & \\
\hline Total: & 87 & & 66 & & 21 & & \\
\hline
\end{tabular}

On the subject of observation by department heads, there was little positive response.

Most teachers responded neutrally to the suggestion of department head observation, but group B teachers were more positive about department heads and other teacher 
leaders observing their classrooms. When the committee at the test school set goal number 5, they were requesting for evaluation to be derived less from job-performance more from collegial discussions and conferences with both sides learning. In this way, evaluation can be truly formative. These results suggest that collegial relationships in the group A schools and in the test school do now exist and that teachers are willing to have supervisory staff on the scene more frequently as they instruct. The central tendency (Table 4.8) indicates teachers did not agree that they wished they were observed by departmental leadership or by teacher leaders. Teachers in the test school (group B) are marginally more amenable to observation and evaluation than group $\mathrm{AB}$.

Table 4.8. Central Tendency Question 4:

\begin{tabular}{lccc}
\hline & & $\begin{array}{c}\text { Subgroup A: Non- } \\
\text { Test School }\end{array}$ & $\begin{array}{c}\text { Sub-Group B:Test } \\
\text { School Teachers }\end{array}$ \\
\hline Measures & Group AB & Teachers & -.15 \\
Median & -.258 & -.285 & 0 \\
Mode & 0 & 0 & 0 \\
\hline
\end{tabular}

Question 5: When I am observed, I am given helpful feedback about how I am doing in my teaching. This question arises from goals one and two listed above and from researchers such as Danielson (1996, 2000, and 2001) and Beerens (2000). Teachers need substantive feedback if they are to improve their practice. This feedback must be framed correctly and truthfully so that it will be received professionally. When I attended the ETS Pathwise Conferences, appraisers were specifically trained to collect evidence and to present that objective evidence in conference to the teacher. One specific guideline is to avoid generalization. Instead, writing down the teachers exact words or counting and giving numeric data often can provide feedback without inducing an emotional reaction from the teacher. Instead, teacher will rationally reflect on how these data factor into their practice and the feedback can be beneficial—at least that is the goal. 
The results of the question five are in Table 4.9 .

Table 4.9. Question 5: When I am observed, I am given helpful feedback about how I am doing in my teaching.

\begin{tabular}{|c|c|c|c|c|c|c|c|}
\hline Response & $\begin{array}{c}\text { Group AB: } \\
\text { Number } \\
\text { of Teachers }\end{array}$ & $\%$ & $\begin{array}{c}\text { Subgroup } \\
\text { A: } \\
\text { Non-Test } \\
\text { School } \\
\text { Teachers } \\
\end{array}$ & $\%$ & $\begin{array}{c}\text { Subgroup } \\
\text { B: } \\
\text { Test } \\
\text { School } \\
\text { Teachers } \\
\end{array}$ & $\%$ & $\begin{array}{c}\text { Difference } \\
\text { Subgroup A } \\
\text { Subgroup B } \\
\end{array}$ \\
\hline $\begin{array}{l}\text { Strongly } \\
\text { Agree }\end{array}$ & 20 & $23 \%$ & 16 & $15 \%$ & 4 & $19 \%$ & $+4 \%$ \\
\hline Agree & 57 & $66 \%$ & 44 & $67 \%$ & 14 & $67 \%$ & 0 \\
\hline $\begin{array}{l}\text { Neither } \\
\text { Agree Nor } \\
\text { Disagree }\end{array}$ & 8 & $9 \%$ & 7 & $8 \%$ & 1 & $5 \%$ & -3 \\
\hline Disagree & 2 & $2 \%$ & 0 & 0 & 2 & $10 \%$ & \\
\hline $\begin{array}{l}\text { Strongly } \\
\text { Disagree }\end{array}$ & 0 & 0 & 0 & 0 & 0 & 0 & \\
\hline No Response & 0 & 0 & 0 & 0 & 0 & 0 & \\
\hline Total: & 87 & & 66 & & 21 & & \\
\hline
\end{tabular}

These data suggest that teachers generally are getting helpful feedback and that they believe it helps them with their teaching. Any teacher who wants to be effective will welcome suggestions and feedback as long as the teacher feels that the evaluator is looking out for her best and for the good of the students.

Table 4.10. Central Tendency Question 5

\begin{tabular}{|c|c|c|c|}
\hline Measures & Group $A B$ & $\begin{array}{c}\text { Subgroup A: Non- } \\
\text { Test School } \\
\text { Teachers } \\
\end{array}$ & $\begin{array}{l}\text { Sub-Group B:Test } \\
\text { School Teachers }\end{array}$ \\
\hline Mean & 1.08 & 1.12 & .95 \\
\hline Median & 1 & 1 & 1 \\
\hline Mode & 1 & 1 & 1 \\
\hline
\end{tabular}

There is a consensus on this question that helpful feedback is being given, although the mean is slightly lower in the test school.

Question 6: When I am observed, the observers seem to be watching both teacher (me and the environment) and the learners (my students and their activities). As educational philosophy has shifted to a more student-centered paradigm, evaluation also has changed. Writers like Iwanicki (2001) and Danielson (1996, 2000, and 2001) address the need for 
evaluations to become less focused on teacher performance and more focused on how teachers connect with individuals, engage students, and create viable learning environments. Therefore the rubric for effective teaching has shifted to include observation of how teachers connect with student. This question specifically arises from goal \#1 of the evaluation committee discussion: student learning. The results from this question are in table 4.11 .

Table 4.11. Question 6: When I am observed, the observers seem to be watching both teacher (me and the environment) and the learners (my students and their activities).

\begin{tabular}{|c|c|c|c|c|c|c|c|}
\hline Response & $\begin{array}{c}\text { Group AB: } \\
\text { Number } \\
\text { of Teachers }\end{array}$ & $\%$ & $\begin{array}{c}\text { Subgroup } \\
\text { A: } \\
\text { Non-Test } \\
\text { School } \\
\text { Teachers }\end{array}$ & $\%$ & $\begin{array}{c}\text { Subgroup } \\
\text { B: } \\
\text { Test } \\
\text { School } \\
\text { Teachers }\end{array}$ & $\%$ & $\begin{array}{c}\text { Difference } \\
\text { Subgroup A- } \\
\text { Subgroup B }\end{array}$ \\
\hline $\begin{array}{l}\text { Strongly } \\
\text { Agree }\end{array}$ & 24 & $28 \%$ & 18 & $27 \%$ & 6 & $29 \%$ & $+2 \%$ \\
\hline Agree & 58 & $67 \%$ & 42 & $64 \%$ & 16 & $76 \%$ & $+12 \%$ \\
\hline $\begin{array}{l}\text { Neither } \\
\text { Agree Nor } \\
\text { Disagree }\end{array}$ & 4 & $5 \%$ & 4 & $7 \%$ & 0 & 0 & $-7 \%$ \\
\hline Disagree & 1 & $1 \%$ & 1 & $1 \%$ & 0 & & $-1 \%$ \\
\hline $\begin{array}{l}\text { Strongly } \\
\text { Disagree }\end{array}$ & 0 & & 0 & & 0 & & \\
\hline No Response & 0 & & 0 & & 0 & & \\
\hline Total: & 87 & & 66 & & 21 & & \\
\hline
\end{tabular}

\section{Discussion}

For this question, group B has a much more positive response, indicating that teachers perceive that observers are watching the behavior of the students in the classrooms of the group B teachers, and that teachers know that their engagement of learners is important in the evaluation process. This understanding represents a shift from the previously practiced observation which involved a checklist of teacher competencies. Checklists seemed to check teaching but seemed to put less emphasis on student affect, learning, and the management of non-teacher centered activities. One goal of the new evaluation system at the test school was to promote student learning and to encourage teachers away 
from teaching by telling. As they wisely orchestrate learning activities, teachers can hope to raise student achievement. The evaluation system sought to encourage cooperative learning, computer-aided instruction, and other more student-centered instruction.

Table 4.12. Central Tendency Question 6

\begin{tabular}{lccc}
\hline & \multicolumn{3}{c}{ Subgroup 1: Non- } \\
Measures & Group AB & Test School & Sub-Group 2:Test \\
Mean & 1.21 & Teachers & School Teachers \\
Median & 1 & 1.1 & 1.3 \\
Mode & 1 & 1 & 1 \\
\hline
\end{tabular}

Question 7: I wish the principal or assistant principal would observe my classroom more. This question is almost directly quoted from a Hong Kong study ${ }^{2}$ that examines appraiser-appraisee relationship in the teacher evaluation process. In Chow's study, teachers were more inclined to have the principal evaluate them than they were to have the more qualified department leadership because the principal was more likely to be easier on them. Table 4.13 shows the results of this question in my study.

Table 4.13. Question 7: I wish the principal and assistant principal would observe my classroom more.

\begin{tabular}{|c|c|c|c|c|c|c|c|}
\hline Response & $\begin{array}{l}\text { Group AB: } \\
\text { Number } \\
\text { of Teachers }\end{array}$ & $\%$ & $\begin{array}{c}\text { Subgroup } \\
\text { A: } \\
\text { Non-Test } \\
\text { School } \\
\text { Teachers } \\
\end{array}$ & $\%$ & $\begin{array}{c}\text { Subgroup } \\
\text { B: } \\
\text { Test } \\
\text { School } \\
\text { Teachers }\end{array}$ & $\%$ & $\begin{array}{c}\text { Difference } \\
\text { Subgroup A- } \\
\text { Subgroup B }\end{array}$ \\
\hline $\begin{array}{l}\text { Strongly } \\
\text { Agree }\end{array}$ & 3 & $3 \%$ & 2 & $3 \%$ & 1 & $5 \%$ & $+2 \%$ \\
\hline Agree & 15 & $17 \%$ & 10 & $15 \%$ & 5 & $24 \%$ & $+9 \%$ \\
\hline $\begin{array}{l}\text { Neither } \\
\text { Agree Nor } \\
\text { Disagree }\end{array}$ & 39 & $45 \%$ & 33 & $50 \%$ & 6 & $29 \%$ & $-21 \%$ \\
\hline Disagree & 22 & $25 \%$ & 15 & $23 \%$ & 7 & $33 \%$ & $+4 \%$ \\
\hline $\begin{array}{l}\text { Strongly } \\
\text { Disagree }\end{array}$ & 6 & $6 \%$ & 5 & $6 \%$ & 1 & $1 \%$ & $-1 \%$ \\
\hline No Response & 1 & $1 \%$ & 0 & & 1 & & \\
\hline Total: & 87 & & 66 & & 21 & & \\
\hline
\end{tabular}

Similar to Chow's Study in Hong Kong, teachers are generally not positive about teacher observation, especially by authorities in the school. Similarly, it appears that teachers feel 
more negatively toward department head observation than toward observation by administration. Note that mean response for question 7 is not as negative as for question 4. There appears to be little difference between responses from groups A and B. Teachers in group A seem more apathetic to administrative observation than group B as represented by a $50 \%$ "neither" response in group A, while responses are more evenly spread among agree, disagree and neither in group B.

Table 4.14. Central Tendency Question 7

\begin{tabular}{|c|c|c|c|}
\hline Measures & Group $A B$ & $\begin{array}{c}\text { Subgroup A: Non- } \\
\text { Test School } \\
\text { Teachers }\end{array}$ & $\begin{array}{l}\text { Sub-Group B:Test } \\
\text { School Teachers }\end{array}$ \\
\hline Mean & -.12 & -.13 & -.1 \\
\hline Median & 0 & 0 & 0 \\
\hline Mode & 0 & 0 & 0 \\
\hline
\end{tabular}

Figure 4.2 Central Tendency of Question 7

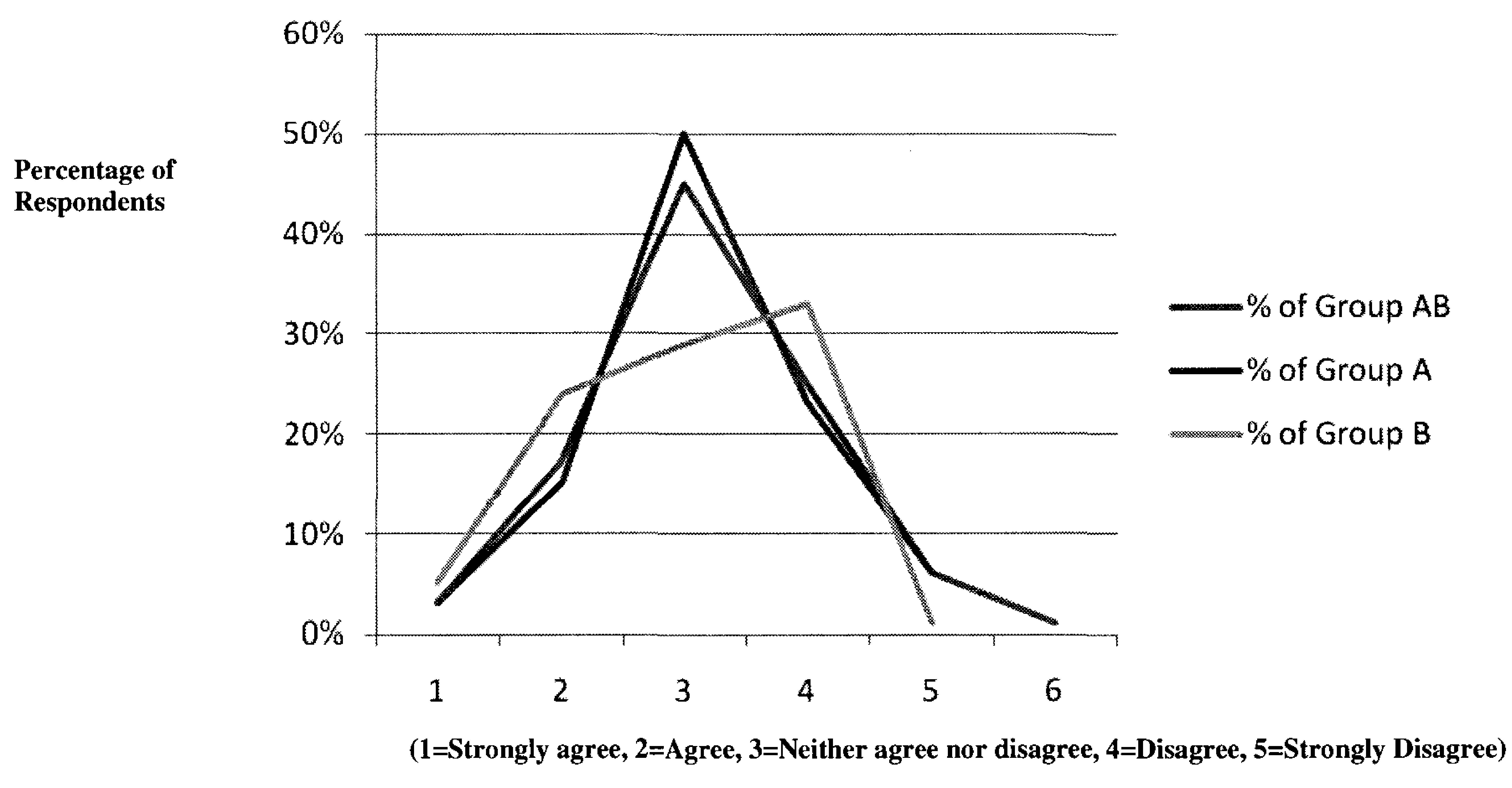

\section{Discussion}

Because of variable factors like personality and learning styles, it is doubtful that some teachers would ever embrace evaluation, but school administration can decrease the negative attitude about evaluation by observing more frequently and offering positive 
morale boosters like thank you notes and collegial discussion about the visits. $\mathrm{Xu}$ recommends that principals "downplay classroom observations and also use more than one person to judge the quality of teacher performance." He also observes "adverse effects of being the only evaluator in a school" which "become obvious when the principal experiences the potential conflict between leading instructional improvement and ... [making] administrative decisions." ${ }^{3}$ With this potential conflict in mind, the principal should remember that schools with more frequent observation tend to have less negative affect relative to teacher observation. Another way of combating negative affect toward classroom observation is to have teachers evaluate the administration. "Teachers should be encouraged to evaluate principals. This is likely to establish a sense of equality and a tone of collaboration for learning from each other."4

Question 8: During my formal evaluations, I feel I have sufficient input as my evaluators complete the appraisal process. The Pathwise training specifically endorsed the need to change the perception of teacher evaluation from an top-down administrative practice to a cooperative collegial process with pre and post conferences and ample opportunities for teachers to be directly involved so that evaluation becomes more than a "smile and sign" annual ritual. The following quotes from Kimball's qualitative study indicate reactions of two teachers to a more collegial standards-based teacher evaluation system: "'The evaluations are more two-way, I think. In the past, you just went in and sat down and they did the form. Now, I'm more of a participator in the evaluation process' ... 'The big difference is structure, structure, and structure. The prior [evaluation system] didn't give the classroom teacher much to go on as far as what the expectations were, and this 
one has very fine detail through the standards and rubrics." ${ }^{, 5}$ When teachers have input in the process, they are more likely to grow with the process - to be a part of the process instead to being apart from a process that is done to them. It is critical in such an evaluation system that teachers feel they can express self-awareness of their own strengths and weakness, their questions about, and even disagreement with, the evaluations. The results of question 8 are on table 4.15. Little significant difference exists in this response between group $\mathrm{A}$ and $\mathrm{B}$, indicating that respondents from these schools feel they have sufficient input into their professional evaluations.

Table 4.15. Question 8: During my formal evaluations, I feel I have sufficient input as my evaluators complete the appraisal process.

\begin{tabular}{|c|c|c|c|c|c|c|c|}
\hline Response & $\begin{array}{l}\text { Group AB: } \\
\text { Number } \\
\text { of Teachers }\end{array}$ & $\%$ & $\begin{array}{c}\text { Subgroup } \\
\text { A: } \\
\text { Non-Test } \\
\text { School } \\
\text { Teachers }\end{array}$ & $\%$ & $\begin{array}{c}\text { Subgroup } \\
\text { B: } \\
\text { Test } \\
\text { School } \\
\text { Teachers }\end{array}$ & $\%$ & $\begin{array}{l}\text { Difference } \\
\text { Subgroup A- } \\
\text { Subgroup B }\end{array}$ \\
\hline $\begin{array}{l}\text { Strongly } \\
\text { Agree }\end{array}$ & 13 & $15 \%$ & 10 & $15 \%$ & 3 & $14 \%$ & $-1 \%$ \\
\hline Agree & 61 & $70 \%$ & 46 & $70 \%$ & 15 & $71 \%$ & $+1 \%$ \\
\hline $\begin{array}{l}\text { Neither } \\
\text { Agree Nor } \\
\text { Disagree }\end{array}$ & 10 & $11 \%$ & 8 & $12 \%$ & 2 & $10 \%$ & $-2 \%$ \\
\hline Disagree & 3 & $3 \%$ & 2 & $3 \%$ & 1 & $5 \%$ & $+2 \%$ \\
\hline $\begin{array}{l}\text { Strongly } \\
\text { Disagree }\end{array}$ & 0 & & 0 & & 0 & & \\
\hline No Response & $\overline{0}$ & & 0 & & 0 & & \\
\hline Total: & 87 & & 66 & & $\overline{21}$ & & \\
\hline
\end{tabular}

Question 9: As far as I know, formal evaluations are fair at my school (i.e. no

preferential treatment for gender, race, age, etc.). Creating a fair environment where there is a perception that no preferential treatment exists is an important job for the administrator. In fact, this is a function of trust that can quickly dissolve when any type of discrimination is even perceived, and at that point morale quickly plummets 
Table 4.16. Question 9: As far as I know, formal evaluations are fair at my school (i.e. no preferential treatment for gender, race, age, etc.).

\begin{tabular}{|c|c|c|c|c|c|c|c|}
\hline Response & $\begin{array}{l}\text { Group AB: } \\
\text { Number } \\
\text { of Teachers }\end{array}$ & $\%$ & $\begin{array}{c}\text { Subgroup } \\
\text { A: } \\
\text { Non-Test } \\
\text { School } \\
\text { Teachers }\end{array}$ & $\%$ & $\begin{array}{c}\text { Subgroup } \\
\text { B: } \\
\text { Test } \\
\text { School } \\
\text { Teachers }\end{array}$ & $\%$ & $\begin{array}{c}\text { Difference } \\
\text { Subgroup A- } \\
\text { Subgroup B }\end{array}$ \\
\hline $\begin{array}{l}\text { Strongly } \\
\text { Agree }\end{array}$ & 29 & $33 \%$ & 22 & $33 \%$ & 7 & $33 \%$ & 0 \\
\hline Agree & 54 & $62 \%$ & 40 & $60 \%$ & 14 & $66 \%$ & +6 \\
\hline $\begin{array}{l}\text { Neither } \\
\text { Agree Nor } \\
\text { Disagree }\end{array}$ & 3 & $3 \%$ & 3 & $5 \%$ & 0 & & -5 \\
\hline Disagree & 1 & $1 \%$ & 1 & $2 \%$ & 0 & & -2 \\
\hline $\begin{array}{l}\text { Strongly } \\
\text { Disagree }\end{array}$ & 0 & & 0 & & 0 & & \\
\hline No Response & 0 & & 0 & & 0 & & \\
\hline Total: & 87 & & 66 & & 21 & & \\
\hline
\end{tabular}

irrevocably. Without the trust that administration is acting without discrimination, the benefits of even the best teacher evaluation system will never be realized.

\section{Discussion}

The results reveal that a large proportion of the teachers surveyed do not perceive preferential treatment in their schools' evaluation programs.

Question 10: I believe that my lead teachers and department heads are qualified to judge my competency in my grad level and/ or with my subject. With the focus on school improvement in everyone's mind, it becomes vitally important that department heads and lead teachers take leadership to make the micro-improvements needed. When these improvements are amalgamated, the school improves. But teachers are not likely to follow the leadership of their senior colleagues if they do not perceive them as competent to evaluate and subject them to criticism. The results of question 10 are shown on Table 4:17. Respondents are generally quite confident that their lead teachers and department heads are qualified to judge their competence. Subgroup B expressed considerably less 
confidence in the qualifications of these departmental personnel as the central tendency

shows (table 4.18).

Table 4.17. Question 10: I believe that my lead teachers and department heads are qualified to judge my competency in my grad level and/ or with my subject

\begin{tabular}{|c|c|c|c|c|c|c|c|}
\hline Response & $\begin{array}{l}\text { Group AB: } \\
\text { Number } \\
\text { of Teachers }\end{array}$ & $\%$ & $\begin{array}{c}\text { Subgroup } \\
\text { A: } \\
\text { Non-Test } \\
\text { School } \\
\text { Teachers } \\
\end{array}$ & $\%$ & $\begin{array}{c}\text { Subgroup } \\
\text { B: } \\
\text { Test } \\
\text { School } \\
\text { Teachers } \\
\end{array}$ & $\%$ & $\begin{array}{l}\text { Difference } \\
\text { Subgroup A } \\
\text { Subgroup B }\end{array}$ \\
\hline $\begin{array}{l}\text { Strongly } \\
\text { Agree }\end{array}$ & 17 & $20 \%$ & 14 & $21 \%$ & 3 & $14 \%$ & $-7 \%$ \\
\hline Agree & 46 & $53 \%$ & 36 & $55 \%$ & 10 & $48 \%$ & $-7 \%$ \\
\hline $\begin{array}{l}\text { Neither } \\
\text { Agree Nor } \\
\text { Disagree }\end{array}$ & 18 & $21 \%$ & 14 & $21 \%$ & 4 & $19 \%$ & $-2 \%$ \\
\hline Disagree & 1 & $1 \%$ & 1 & $2 \%$ & $\overline{0}$ & & $-2 \%$ \\
\hline $\begin{array}{l}\text { Strongly } \\
\text { Disagree }\end{array}$ & 1 & $1 \%$ & 0 & 0 & 1 & $5 \%$ & $+5 \%$ \\
\hline No Response & 2 & $2 \%$ & & & 2 & $10 \%$ & $+10 \%$ \\
\hline Total: & 87 & & 66 & & 21 & & \\
\hline
\end{tabular}

Table 4.18. Central Tendency Question 10

\begin{tabular}{|c|c|c|c|}
\hline Measures & Group $A B$ & $\begin{array}{c}\text { Subgroup A: Non- } \\
\text { Test School } \\
\text { Teachers }\end{array}$ & $\begin{array}{l}\text { Sub-Group B:Test } \\
\text { School Teachers }\end{array}$ \\
\hline Mean & .95 & .98 & .78 \\
\hline Median & 1 & 1 & 1 \\
\hline Mode & 1 & 1 & 1 \\
\hline
\end{tabular}

Question 11: Teacher evaluations are thorough and professional at my school.

The overall purpose of revamping the teacher evaluation program was to make it a profitable and professional appraisal system which would yield enhanced learning, instruction, mentoring, collegiality, and professional development. Therefore, it is important for the administration to model utmost professionalism before the faculty. This question was included to measure how professional the administrators are viewed in terms of their functions as instructional supervisors. The data in Table 4.19 reveal that $86 \%$ of teachers in group $\mathrm{AB}$ perceive their school's evaluation system as professional and thorough, meaning that the schools are conducting evaluations that meet 
Table 4.19. Question 11: Teacher evaluations are thorough and professional at my school.

\begin{tabular}{|c|c|c|c|c|c|c|c|}
\hline Response & $\begin{array}{l}\text { Group AB: } \\
\text { Number } \\
\text { of Teachers }\end{array}$ & $\%$ & $\begin{array}{c}\text { Subgroup } \\
\text { A: } \\
\text { Non-Test } \\
\text { School } \\
\text { Teachers }\end{array}$ & $\%$ & $\begin{array}{c}\text { Subgroup } \\
\text { B: } \\
\text { Test } \\
\text { School } \\
\text { Teachers }\end{array}$ & $\%$ & $\begin{array}{c}\text { Difference } \\
\text { Subgroup A- } \\
\text { Subgroup B }\end{array}$ \\
\hline $\begin{array}{l}\text { Strongly } \\
\text { Agree }\end{array}$ & 21 & $24 \%$ & 18 & $21 \%$ & 3 & $14 \%$ & $-7 \%$ \\
\hline Agree & 54 & $62 \%$ & 38 & $58 \%$ & 16 & $76 \%$ & +18 \\
\hline $\begin{array}{l}\text { Neither } \\
\text { Agree Nor } \\
\text { Disagree }\end{array}$ & 7 & $8 \%$ & 5 & $6 \%$ & 2 & $10 \%$ & $+4 \%$ \\
\hline Disagree & 3 & $4 \%$ & 3 & $5 \%$ & 0 & & $-5 \%$ \\
\hline $\begin{array}{l}\text { Strongly } \\
\text { Disagree }\end{array}$ & 0 & & 0 & & 0 & & \\
\hline No Response & 2 & & 2 & & & & \\
\hline Total: & 87 & & 66 & & 21 & & \\
\hline
\end{tabular}

the teachers' definitions of effective. There are differences between subgroups A and B but only in the ranges of agree and strongly agree. The central tendency of the answers is in table 4.20 .

Table 4.20. Central Tendency Question 10

\begin{tabular}{|c|c|c|c|}
\hline Measures & Group $A B$ & $\begin{array}{c}\text { bgroup A: } N \\
\text { Test School } \\
\text { Teachers }\end{array}$ & $\begin{array}{c}\text { Sub-Group B:Test } \\
\text { School Teachers }\end{array}$ \\
\hline Mean & 1.28 & 1.32 & 1.15 \\
\hline Median & 1 & 1 & 1 \\
\hline Mode & 1 & 1 & 1 \\
\hline
\end{tabular}

A comparison of the means shows slightly more agreement among subgroup A.

Question 12: I believe my principal and assistant principal are qualified to judge my competency in my grade level and/or subject. This question is related once again to questions 4, 7, and 10. Chow (2002) ran a similar survey in Hong Kong which revealed that teachers were generally confident in their principals' qualification to judge their competence and the results of question 12 reveal the same perception. 
Table 4.21. Question 12: I believe my principal and assistant principal are qualified to judge my competency in my grade level and/or subject.

\begin{tabular}{|c|c|c|c|c|c|c|c|}
\hline Response & $\begin{array}{l}\text { Group AB: } \\
\text { Number } \\
\text { of Teachers }\end{array}$ & $\%$ & $\begin{array}{c}\text { Subgroup } \\
\text { A: } \\
\text { Non-Test } \\
\text { School } \\
\text { Teachers } \\
\end{array}$ & $\%$ & $\begin{array}{c}\text { Subgroup } \\
\text { B: } \\
\text { Test } \\
\text { School } \\
\text { Teachers } \\
\end{array}$ & $\%$ & $\begin{array}{l}\text { Difference } \\
\text { Subgroup A- } \\
\text { Subgroup B }\end{array}$ \\
\hline $\begin{array}{l}\text { Strongly } \\
\text { Agree }\end{array}$ & 23 & $26 \%$ & 19 & $29 \%$ & 4 & $19 \%$ & $-10 \%$ \\
\hline$\overline{\text { Agree }}$ & 51 & $59 \%$ & 36 & $55 \%$ & 15 & $71 \%$ & $+16 \%$ \\
\hline $\begin{array}{l}\text { Neither } \\
\text { Agree Nor } \\
\text { Disagree } \\
\end{array}$ & 11 & $13 \%$ & 10 & $15 \%$ & 1 & $5 \%$ & $-10 \%$ \\
\hline Disagree & 2 & $2 \%$ & 1 & $2 \%$ & 1 & $5 \%$ & $+3 \%$ \\
\hline $\begin{array}{l}\text { Strongly } \\
\text { Disagree }\end{array}$ & 0 & & 0 & & 0 & & \\
\hline \multicolumn{8}{|l|}{ No Response } \\
\hline Total: & 87 & & 66 & & 21 & & \\
\hline
\end{tabular}

Positive response predominates on this question as group $\mathrm{AB}$ either agrees or strongly agrees $85 \%$ of the time. Subgroup B responds agreeably in $90 \%$ of responses. Negative responses were few indicating that teachers in a majority of cases believe their supervisors have the qualifications to judge their competence. The central tendency is indicated in Table 4.22 .

Table 4.22. Central Tendency Question 12

\begin{tabular}{lccc} 
& & Subgroup A: Non- & \\
Measures & Test School & Sub-Group B:Test \\
Mean & Teachers & School Teachers \\
\hline Median & 1.022 & 1.1045 & 1.05 \\
Mode & 1 & 1 & 1 \\
\hline
\end{tabular}

\section{Discussion}

With as much confidence as teachers apparently have in their administrators, it is clear that instructional leadership either is or has the potential of being very powerfully employed in these schools.

Question 13: At my school standard for evaluation are clearly explained. As the 
standards-based teacher evaluation system was implemented at the test school, the assistant principal, who was designated at the academic leader under the principal, explained all the aspects of the new system. The responses to the question are in table 4.23 .

Table 4.23. Question 13: At my school standard for evaluation are clearly explained

\begin{tabular}{|c|c|c|c|c|c|c|c|}
\hline Response & $\begin{array}{l}\text { Group AB: } \\
\text { Number } \\
\text { of Teachers }\end{array}$ & $\%$ & $\begin{array}{c}\text { Subgroup } \\
\text { A: } \\
\text { Non-Test } \\
\text { School } \\
\text { Teachers } \\
\end{array}$ & $\%$ & $\begin{array}{c}\text { Subgroup } \\
\text { B: } \\
\text { Test } \\
\text { School } \\
\text { Teachers } \\
\end{array}$ & $\%$ & $\begin{array}{c}\text { Difference } \\
\text { Subgroup A- } \\
\text { Subgroup B }\end{array}$ \\
\hline $\begin{array}{l}\text { Strongly } \\
\text { Agree }\end{array}$ & 16 & $18 \%$ & 15 & $23 \%$ & 1 & $5 \%$ & $-18 \%$ \\
\hline Agree & 59 & $68 \%$ & 42 & $64 \%$ & 17 & $81 \%$ & $+17 \%$ \\
\hline $\begin{array}{l}\text { Neither } \\
\text { Agree Nor } \\
\text { Disagree }\end{array}$ & 10 & $11 \%$ & 8 & $12 \%$ & 2 & $10 \%$ & $-2 \%$ \\
\hline Disagree & 1 & $1 \%$ & $\overline{1}$ & $2 \%$ & $\overline{0}$ & & $-2 \%$ \\
\hline $\begin{array}{l}\text { Strongly } \\
\text { Disagree }\end{array}$ & 1 & $1 \%$ & & & 1 & $5 \%$ & $+5 \%$ \\
\hline No Response & $\overline{0}$ & & 0 & & 0 & & \\
\hline Total: & 87 & & 66 & & 21 & & \\
\hline
\end{tabular}

Teachers agree with a large majority $(75 \%)$ that standards of evaluation are clearly explained. Responses of subgroups were very similar, though group B did not agree as strongly.

Table 4.24. Central Tendency Question 13

\begin{tabular}{lccc}
\hline & \multicolumn{3}{c}{ Subgroup A: } \\
Measures & Gon-Test School & Sub-Group B: \\
Mean & 1.092 & Teachers & Test School Teachers \\
Median & 1 & 1.05 & 1.1 \\
Mode & 1 & 1 & 1 \\
\hline
\end{tabular}

\section{Discussion:}

The goal of extensive introductory explanation was two-fold: (1) The explanation set forth the plan for instructional expectations, and (2) it was agreed that it was only fair to the teachers that the standards and rubrics that would be used to evaluate their 
professional practice be in their hands at the outset of each year.

Question 14: I believe my teacher evaluations have helped me to improve as a professional educator. Much of the preparation to update and professionalize the teacher evaluation system at the test school was conducted to change what one writer reports was a "perfunctory and meaningless bureaucratic necessity ... into a meaningful process that is viewed as the catalyst for improving teaching and learning in schools." ${ }^{\circ 6}$ The second goal of administration and committees was to improve instruction and then student learning. So the question was created to find whether teachers in general find evaluation helpful or not.

Table 4.25. Question 14: I believe that my teacher evaluations have helped me to improve as a professional educator.

\begin{tabular}{|c|c|c|c|c|c|c|c|}
\hline Response & $\begin{array}{l}\text { Group AB: } \\
\text { Number } \\
\text { of Teachers }\end{array}$ & $\%$ & $\begin{array}{c}\text { Subgroup } \\
\text { A: } \\
\text { Non-Test } \\
\text { School } \\
\text { Teachers }\end{array}$ & $\%$ & $\begin{array}{c}\text { Subgroup } \\
\text { B: } \\
\text { Test } \\
\text { School } \\
\text { Teachers }\end{array}$ & $\%$ & $\begin{array}{c}\text { Difference } \\
\text { Subgroup A- } \\
\text { Subgroup B }\end{array}$ \\
\hline $\begin{array}{l}\text { Strongly } \\
\text { Agree }\end{array}$ & 16 & $18 \%$ & 14 & $21 \%$ & 2 & $10 \%$ & $-11 \%$ \\
\hline Agree & 58 & $67 \%$ & 43 & $65 \%$ & 15 & $71 \%$ & $+6 \%$ \\
\hline $\begin{array}{l}\text { Neither } \\
\text { Agree Nor } \\
\text { Disagree }\end{array}$ & 10 & $11 \%$ & 8 & $12 \%$ & 2 & $10 \%$ & $-2 \%$ \\
\hline Disagree & 2 & $2 \%$ & 1 & $2 \%$ & 1 & $5 \%$ & $-3 \%$ \\
\hline $\begin{array}{l}\text { Strongly } \\
\text { Disagree }\end{array}$ & 1 & $1 \%$ & & & 1 & $5 \%$ & \\
\hline No Response & 0 & & $\overline{0}$ & & $\overline{0}$ & & \\
\hline Total: & 87 & & 66 & & 21 & & \\
\hline
\end{tabular}

In group $\mathrm{AB} 85 \%$ of respondents agreed that their work as professional educators had benefitted from teacher evaluation. In subgroup B, the test school, the result was that $81 \%$ found their work as a teacher was improved through teacher evaluation. 


\begin{tabular}{lccc} 
Measures & Group AB & Teachers & Test School Teachers \\
\hline Mean & 1.022 & 1.09 & .8 \\
Median & 1 & 1 & 1 \\
Mode & 1 & 1 & 1 \\
\hline
\end{tabular}

\section{Discussion:}

The results from question 14 should be encouraging to professional administrators that thorough evaluation is not a "poor use of [their] time." It holds the promise of helping teachers at all stages in their careers to develop into more effective teachers and then to bring students to higher levers of achievement.

Question 15: My teacher evaluations usually contain a good balance between encouraging positive comments and suggestions for improvement and growth. Milanowski commented in his qualitative study that many administrators had trouble "providing timely and specific feedback that teachers could use to help them improve their practice ... In most cases the feedback they described was a confirmation that the teacher was doing well rather than suggestions for improvement. A significant number . . . told us they had received no feedback, or that feedback that was too general to help them improve."8 Timely, specific feedback is critical to facilitate change. Good evaluations must be formative before they are summative, but usually they are put terms of agreeable answers and non-agreeable. Group $\mathrm{AB}$ agreed $89 \%$ of the time with subgroup A responding more strongly than subgroup B. 
Table 4.27. Question 15: My teacher evaluations usually contain a good balance between encouraging positive comments and suggestions for improvement and growth.

\begin{tabular}{|c|c|c|c|c|c|c|c|}
\hline Response & $\begin{array}{l}\text { Group AB: } \\
\text { Number } \\
\text { of Teachers }\end{array}$ & $\%$ & $\begin{array}{c}\text { Subgroup } \\
\text { A: } \\
\text { Non-Test } \\
\text { School } \\
\text { Teachers }\end{array}$ & $\%$ & $\begin{array}{c}\text { Subgroup } \\
\text { B: } \\
\text { Test } \\
\text { School } \\
\text { Teachers }\end{array}$ & $\%$ & $\begin{array}{l}\text { Difference } \\
\text { Subgroup A- } \\
\text { Subgroup B }\end{array}$ \\
\hline $\begin{array}{l}\text { Strongly } \\
\text { Agree }\end{array}$ & 24 & $28 \%$ & 21 & $32 \%$ & 3 & $14 \%$ & $-18 \%$ \\
\hline Agree & 53 & $61 \%$ & 37 & $56 \%$ & 16 & $76 \%$ & $+20 \%$ \\
\hline $\begin{array}{l}\text { Neither } \\
\text { Agree Nor } \\
\text { Disagree }\end{array}$ & 7 & $8 \%$ & 5 & $8 \%$ & 2 & $10 \%$ & $+2 \%$ \\
\hline Disagree & 3 & $3 \%$ & 3 & $5 \%$ & 0 & & $-5 \%$ \\
\hline $\begin{array}{l}\text { Strongly } \\
\text { Disagree }\end{array}$ & 0 & & 0 & & 0 & & \\
\hline No Response & 0 & & 0 & & 0 & & \\
\hline Total: & 87 & & 66 & & 21 & & \\
\hline
\end{tabular}

Table 4.28. Central Tendency Question 15

\begin{tabular}{lccc}
\hline & \multicolumn{3}{c}{ Subgroup A: } \\
Measures & Non-Test School & Sub-Group B: \\
\hline Mean & 1.13 & Teachers & Test School Teachers \\
Median & 1 & 1.149 & 1.05 \\
Mode & 1 & 1 & 1 \\
\hline
\end{tabular}

\section{Discussion:}

Teachers generally perceive that comments on their evaluations contain a good number of encouraging, positive remarks and suggestions for growth. For the evaluator, the former are always easier to give than the latter, but both are vital if evaluation is to be a worthwhile exercise of instructional leadership. Teachers in this survey feel they receive a good balance between the two types of feedback.

Question 16: My evaluations have sufficient positive comments and suggestions for improvement. Though this item may seem redundant with question 15 , this question and question 17 are responses to the idea that teacher evaluations are normally weak on comments, especially comments that could be negative or that call for a changes or 
growth on the teacher's part. Responses to question 16 were very positive also.

Teachers from Group $\mathrm{AB}$ agreed with the statement in $97 \%$ of responses. Groups $\mathrm{A}$ and

B were very similar with little difference. Responses to question 16 were very positive

also. Teachers from Group $\mathrm{AB}$ agreed with the statement in $97 \%$ of responses. Groups

A and B were very similar with little difference.

Table 4.29. Question 16: My evaluations have sufficient positive comments and encouraging feedback.

\begin{tabular}{|c|c|c|c|c|c|c|c|}
\hline Response & $\begin{array}{l}\text { Group AB: } \\
\text { Number } \\
\text { of Teachers }\end{array}$ & $\%$ & $\begin{array}{c}\text { Subgroup } \\
\text { A: } \\
\text { Non-Test } \\
\text { School } \\
\text { Teachers } \\
\end{array}$ & $\%$ & $\begin{array}{c}\text { Subgroup } \\
\text { B: } \\
\text { Test } \\
\text { School } \\
\text { Teachers } \\
\end{array}$ & $\%$ & $\begin{array}{l}\text { Difference } \\
\text { Subgroup A- } \\
\text { Subgroup B }\end{array}$ \\
\hline $\begin{array}{l}\text { Strongly } \\
\text { Agree }\end{array}$ & 31 & $36 \%$ & 25 & $38 \%$ & 6 & $29 \%$ & $-9 \%$ \\
\hline Agree & 53 & $61 \%$ & 39 & $59 \%$ & 14 & $67 \%$ & $+8 \%$ \\
\hline $\begin{array}{l}\text { Neither } \\
\text { Agree Nor } \\
\text { Disagree }\end{array}$ & 2 & $2 \%$ & 1 & $2 \%$ & 1 & $5 \%$ & $+3 \%$ \\
\hline Disagree & 1 & $1 \%$ & 1 & $2 \%$ & 0 & & \\
\hline $\begin{array}{l}\text { Strongly } \\
\text { Disagree }\end{array}$ & 0 & & 0 & & 0 & & \\
\hline No Response & 0 & & 0 & & 0 & & \\
\hline Total: & 87 & & 66 & & 21 & & \\
\hline
\end{tabular}

Table 4.30. Central Tendency Question 16

Subgroup A:

Non-Test School

\begin{tabular}{lccc} 
Measures & Group AB & Teachers & Test School Teachers \\
\hline Mean & 1.32 & 1.34 & 1.25 \\
\hline Median & 1 & 1 & 1 \\
\hline Mode & 1 & 1 & 1 \\
\hline
\end{tabular}

Question 17: My evaluations have enough suggestions for improvement. Respondents in group $\mathrm{AB}$ agreed with the statement in $89 \%$ of cases, indicating that evaluators are placing a sufficient number of suggestions for improvement on evaluations. Group A and group B had congruent results. Responses are presented on table 4.31 . 
Table 4.31. Question 17: My evaluations have enough suggestions for improvement.

\begin{tabular}{|c|c|c|c|c|c|c|c|}
\hline Response & $\begin{array}{l}\text { Group AB: } \\
\text { Number } \\
\text { of Teachers }\end{array}$ & $\%$ & $\begin{array}{c}\text { Subgroup } \\
\text { A: } \\
\text { Non-Test } \\
\text { School } \\
\text { Teachers }\end{array}$ & $\%$ & $\begin{array}{c}\text { Subgroup } \\
\text { B: } \\
\text { Test } \\
\text { School } \\
\text { Teachers }\end{array}$ & $\%$ & $\begin{array}{l}\text { Difference } \\
\text { Subgroup A- } \\
\text { Subgroup B }\end{array}$ \\
\hline $\begin{array}{l}\text { Strongly } \\
\text { Agree }\end{array}$ & 16 & $18 \%$ & 15 & $23 \%$ & 1 & $5 \%$ & $-18 \%$ \\
\hline Agree & 62 & $71 \%$ & 44 & $67 \%$ & 18 & $86 \%$ & $+19 \%$ \\
\hline $\begin{array}{l}\text { Neither } \\
\text { Agree Nor } \\
\text { Disagree }\end{array}$ & 6 & $7 \%$ & 5 & $8 \%$ & 1 & $5 \%$ & $-3 \%$ \\
\hline Disagree & 3 & $3 \%$ & 2 & $3 \%$ & $\overline{1}$ & $5 \%$ & $+2 \%$ \\
\hline \multicolumn{8}{|l|}{$\begin{array}{l}\text { Strongly } \\
\text { Disagree } \\
\end{array}$} \\
\hline \multicolumn{8}{|l|}{ No Response } \\
\hline Total: & 87 & & 66 & & 21 & & \\
\hline
\end{tabular}

\begin{tabular}{lccc}
\hline Table 4.32. Central Tendency Question 17 & Subgroup A: \\
\hline & & Non-Test School & Sub-Group B: \\
Measures & Group AB & Teachers & Test School Teachers \\
\hline Mean & 1.05 & 1.1 & .9 \\
Median & 1 & 1 & 1 \\
Mode & 1 & 1 & 1 \\
\hline
\end{tabular}

Question 18: Professional development activities at my school - such as pre-service, in-

service, conventions, etc. - help me as a teacher. While effective instructional

leadership involves supervision and evaluation, teacher improvement involves

professional growth and development. While most schools have professional

development programs, questions abound about the effectiveness of these activities.

Questions 18-20 focus on professional development. Table 4.33 and figure 4.3 reveal the responses to question 18 . 
Table 4.33. Question 18: Professional development activities at my school - such as pre-service, inservice, conventions, etc. - help me as a teacher.

\begin{tabular}{|c|c|c|c|c|c|c|c|}
\hline Response & $\begin{array}{l}\text { Group AB: } \\
\text { Number } \\
\text { of Teachers }\end{array}$ & $\%$ & $\begin{array}{c}\text { Subgroup } \\
\text { A: } \\
\text { Non-Test } \\
\text { School } \\
\text { Teachers } \\
\end{array}$ & $\%$ & $\begin{array}{c}\text { Subgroup } \\
\text { B: } \\
\text { Test } \\
\text { School } \\
\text { Teachers }\end{array}$ & $\%$ & $\begin{array}{l}\text { Difference } \\
\text { Subgroup A } \\
\text { Subgroup B }\end{array}$ \\
\hline $\begin{array}{l}\text { Strongly } \\
\text { Agree }\end{array}$ & 19 & $22 \%$ & 17 & $26 \%$ & 2 & $10 \%$ & $-16 \%$ \\
\hline Agree & 37 & $43 \%$ & 31 & $47 \%$ & 6 & $29 \%$ & $-16 \%$ \\
\hline $\begin{array}{l}\text { Neither } \\
\text { Agree Nor } \\
\text { Disagree } \\
\end{array}$ & 12 & $14 \%$ & 9 & $14 \%$ & 3 & $14 \%$ & 0 \\
\hline Disagree & 18 & $21 \%$ & 9 & $14 \%$ & 8 & $38 \%$ & $+24 \%$ \\
\hline $\begin{array}{l}\text { Strongly } \\
\text { Disagree }\end{array}$ & 2 & $2 \%$ & & & 2 & $10 \%$ & $+10 \%$ \\
\hline \multicolumn{8}{|l|}{ No Response } \\
\hline Total: & 87 & & 66 & & 21 & & \\
\hline
\end{tabular}

Figure 4.3 Comparison of Response Groups / Question 18

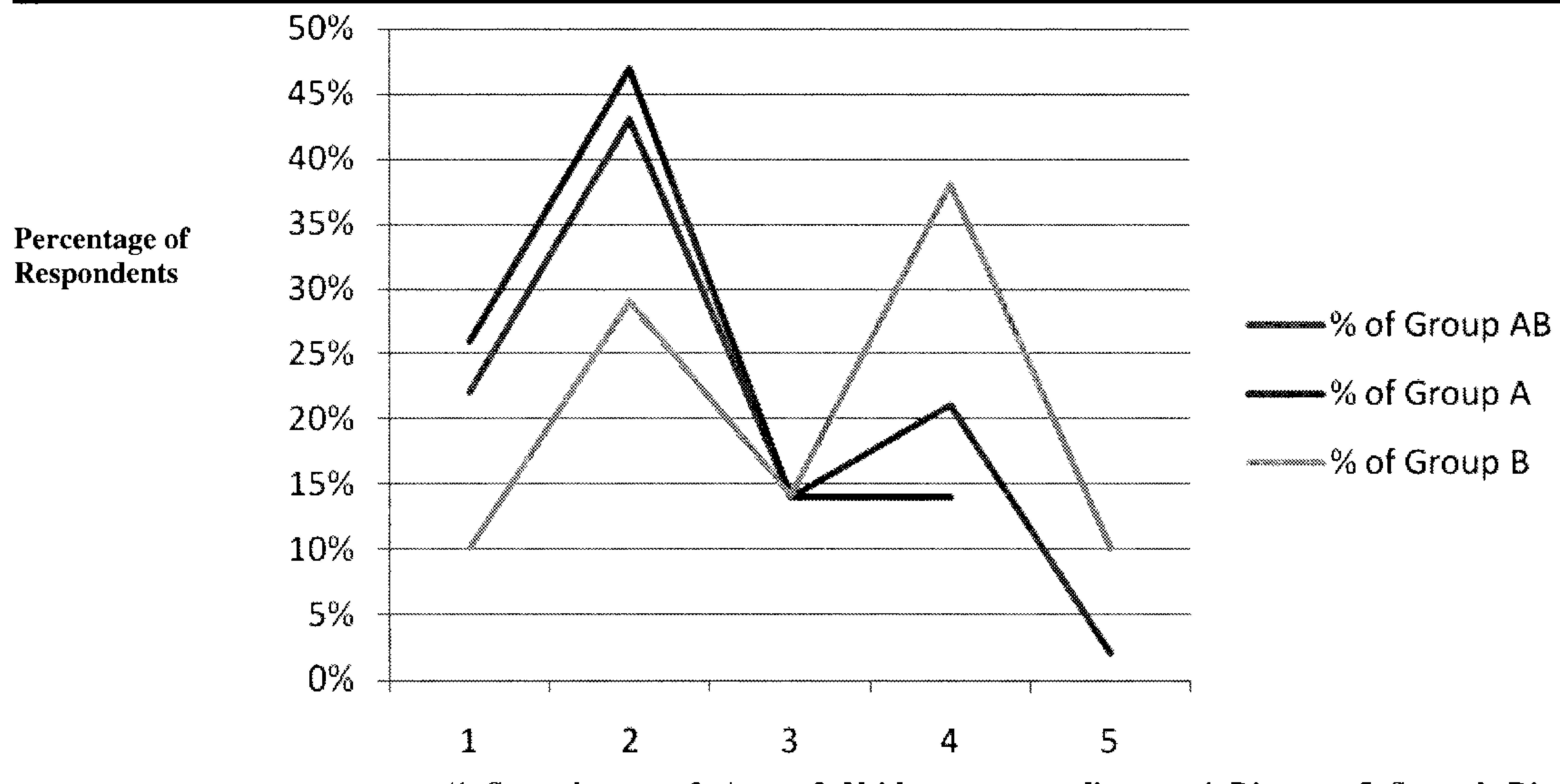

(1=Strongly agree, $2=$ =Agree, $3=$ Neither agree nor disagree, 4=Disagree, $5=$ =Strongly Disagree)

In this question there is a remarkable difference between group A and group B. Group A tends to agree that on-site professional development activities help teaching and learning, with $73 \%$ or respondents choosing responses that indicate agreement. Among group A there $28 \%$ of respondents who disagreed about the value of professional development. There was an obvious correlation between responses to this question and 
the test school, but further correlation tests within the study revealed a statistically significant correlation between the type of teacher assignment (elementary/secondary)

Table 4.34. Central Tendency Question 18

\begin{tabular}{|c|c|c|c|}
\hline Measures & Group $A B$ & $\begin{array}{c}\text { Subgroup A: } \\
\text { Non-Test School } \\
\text { Teachers } \\
\end{array}$ & $\begin{array}{c}\text { Sub-Group B: } \\
\text { Test School Teachers }\end{array}$ \\
\hline Mean & .63 & .82 & 0 \\
\hline Median & 1 & 1 & 0 \\
\hline Mode & 1 & 1 & 0 \\
\hline
\end{tabular}

and the response to the question. The correlation coefficient was -.33877 indicating an inverse relationship between the level of teaching assignment and the degree of agreement with the question. Secondary teachers tended to disagree with the question more frequently.

\section{Discussion:}

The necessity of effective professional development cannot be underestimated in schools. As indicated in the responses to this survey question, teachers tend to either really like professional development or they have a thorough distaste for it. The professional development programs in districts and in private schools must seek to meet the needs of the professionals in the school. For secondary teachers, there is little motivation to attend group professional development program since their classroom needs vary so widely. Secondary teachers are very specialized, though they also share some commonalities. For the enterprising teacher, professional development is a given. Teachers who are truly dedicated to growing professionally are ready to attend AP training, to go to graduate school, or to take classes at a local university. These individual professional activities are immeasurably more effective for secondary teachers, but many teachers wait for professional development programs to be set up by centralized 
administration. Effective professional development on the secondary level must be primarily individualized. Teacher should be required to engage themselves in professional development or to work in teams or departments, with funds being available as approved by the school administration. The professional development needs of the individual teachers could be revealed in the teacher evaluation process or through the interest of the teacher or the needs of the school.

Question 19: My evaluations have been used to direct individual professional development activities that have helped me as a teacher. One of the reasons that the Pathwise program was attractive to me as the academic assistant principal in the test school was that it so sensibly linked teacher education, teacher testing (the PRAXIS), teacher induction, teacher evaluation, and professional development. The program included training modules that schools or districts could use to hone the skills of teachers. Without the program in hand, we asked teachers to self-evaluate and to identify areas in which they needed growth. We then suggested professional development activities that could help those teachers. A favorite of the principal was a classroom management book that he had read, since several teachers in evaluation conferences cited discipline as a specific area in which they needed to grow. Professional development can continue to spread information or it can focus efforts directly on teacher needs.

The results of question 19 show that once again the perceptions of the test school (group B) are much less agreeable to the question than group A. These data indicates that the professional development activities at the test school are not on par with the schools 
Table 4.35. Question 19: My evaluations have been used to direct individual professional development activities that have helped me as a teacher.

\begin{tabular}{|c|c|c|c|c|c|c|c|}
\hline Response & $\begin{array}{l}\text { Group AB: } \\
\text { Number } \\
\text { of Teachers }\end{array}$ & $\%$ & $\begin{array}{c}\text { Subgroup } \\
\text { A: } \\
\text { Non-Test } \\
\text { School } \\
\text { Teachers } \\
\end{array}$ & $\%$ & $\begin{array}{c}\text { Subgroup } \\
\text { B: } \\
\text { Test } \\
\text { School } \\
\text { Teachers } \\
\end{array}$ & $\%$ & $\begin{array}{c}\text { Difference } \\
\text { Subgroup A- } \\
\text { Subgroup B } \\
\end{array}$ \\
\hline $\begin{array}{l}\text { Strongly } \\
\text { Agree }\end{array}$ & 12 & $14 \%$ & 10 & $15 \%$ & 2 & $10 \%$ & $-5 \%$ \\
\hline Agree & 43 & $49 \%$ & 34 & $51 \%$ & 9 & $43 \%$ & $-8 \%$ \\
\hline $\begin{array}{l}\text { Neither } \\
\text { Agree Nor } \\
\text { Disagree }\end{array}$ & 23 & $26 \%$ & 16 & $24 \%$ & 7 & $33 \%$ & $+9 \%$ \\
\hline Disagree & 8 & $9 \%$ & 5 & $6 \%$ & 3 & $14 \%$ & $+8 \%$ \\
\hline $\begin{array}{l}\text { Strongly } \\
\text { Disagree }\end{array}$ & 1 & $1 \%$ & 1 & $2 \%$ & & & $+2 \%$ \\
\hline No Response & 0 & & 0 & & 0 & & \\
\hline Total: & 87 & & 66 & & 21 & & \\
\hline
\end{tabular}

and districts where the group A teachers work. Another correlation study once again reveals a negative correlation (-.27677) between the school level and question 19.

Table 4.36. Central Tendency Question 19

\begin{tabular}{|c|c|c|c|}
\hline Measures & Group $A B$ & $\begin{array}{c}\text { Subgroup A: } \\
\text { Non-Test School } \\
\text { Teachers }\end{array}$ & $\begin{array}{c}\text { Sub-Group B: } \\
\text { Test School Teachers }\end{array}$ \\
\hline Mean & .643 & .716 & .4 \\
\hline Median & 1 & 1 & 0 \\
\hline Mode & 1 & 1 & 0 \\
\hline
\end{tabular}

\section{Discussion:}

More individualized professional development is a recommendation of this study. If this

type of professional development is to replace the current system of generalized

professional development, administration must set up files that will track each teacher's

progress. Perhaps a system like PACES (Professional Assessment and Comprehensive

Evaluation System) in the Miami-Dade county schools could utilize Web-based

technology to direct independent or group learning. PACES noted its chief goal as 
follows: "The investment of human technical, and financial resources in development the PACES should be primarily centered on professional development to improve teaching, learning, and schools, rather than teacher evaluation." ${ }^{.9}$ PACES based it evaluation on the same standards as Pathwise, but used the following domains:

I. Planning and Preparation

II. Managing the learning environment

III. Teacher/learner relationships

IV. Enhancing and enabling thinking

V. Classroom-based assessment of learning

VI. Professional responsibilities

Each of these domains has rubrics that convey assessment criteria, but more to the point are the training modules contained on the Miami-Dade County Schools Web Site. Each domain contains training for teachers who wish to hone their craft independently. The URL is http://paces.dadeschools.net.

Question 20: I am satisfied with the professional development program in my school / district. The following are the results of the final question of this survey:

Figure 4.37. Question 20: I am satisfied with the professional development program in my school / district

\begin{tabular}{|c|c|c|c|c|c|c|c|}
\hline Response & $\begin{array}{l}\text { Group AB: } \\
\text { Number } \\
\text { of Teachers }\end{array}$ & $\%$ & $\begin{array}{c}\text { Subgroup } \\
\text { A: } \\
\text { Non-Test } \\
\text { School } \\
\text { Teachers }\end{array}$ & $\%$ & $\begin{array}{c}\text { Subgroup } \\
\text { B: } \\
\text { Test } \\
\text { School } \\
\text { Teachers }\end{array}$ & $\%$ & $\begin{array}{l}\text { Difference } \\
\text { Subgroup A- } \\
\text { Subgroup B }\end{array}$ \\
\hline $\begin{array}{l}\text { Strongly } \\
\text { Agree }\end{array}$ & 15 & $17 \%$ & 13 & $20 \%$ & 2 & $10 \%$ & $-10 \%$ \\
\hline$\overline{\text { Agree }}$ & 37 & $43 \%$ & $\overline{32}$ & $48 \%$ & 5 & $24 \%$ & $-24 \%$ \\
\hline $\begin{array}{l}\text { Neither } \\
\text { Agree Nor } \\
\text { Disagree }\end{array}$ & 10 & $11 \%$ & 6 & $9 \%$ & 4 & $19 \%$ & $+10 \%$ \\
\hline Disagree & 23 & $26 \%$ & 14 & $21 \%$ & 9 & $43 \%$ & $+22 \%$ \\
\hline $\begin{array}{l}\text { Strongly } \\
\text { Disagree }\end{array}$ & 2 & $2 \%$ & 1 & $2 \%$ & 1 & $2 \%$ & $+3 \%$ \\
\hline No Response & 0 & & 0 & & 0 & & \\
\hline Total: & 87 & & $\overline{66}$ & & 21 & & \\
\hline
\end{tabular}


The results of this question reveal the same type of tendency of questions 18 and 19. Respondents in group $\mathrm{AB}$ chose agreeable answers $60 \%$ of the time but this is dominated clearly by group A. Group B chose agreeable answers only $25 \%$ of the time and in fact chose disagreeable answers $48 \%$ of the time. The central tendency of the question reveals the strongest level of divergence in the survey.

Table 4.38. Central Tendency Question 20

\begin{tabular}{|c|c|c|c|}
\hline Measures & Group $A B$ & $\begin{array}{c}\text { Subgroup A: } \\
\text { Non-Test School } \\
\text { Teachers } \\
\end{array}$ & $\begin{array}{c}\text { Sub-Group } 2 \\
\text { Test School Teachers }\end{array}$ \\
\hline Mean & .44 & .64 & -0.2 \\
\hline Median & 1 & 1 & 0 \\
\hline Mode & 1 & 1 & 0 \\
\hline
\end{tabular}

Figure 4.4 Comparison of Group A and B for Question 20.

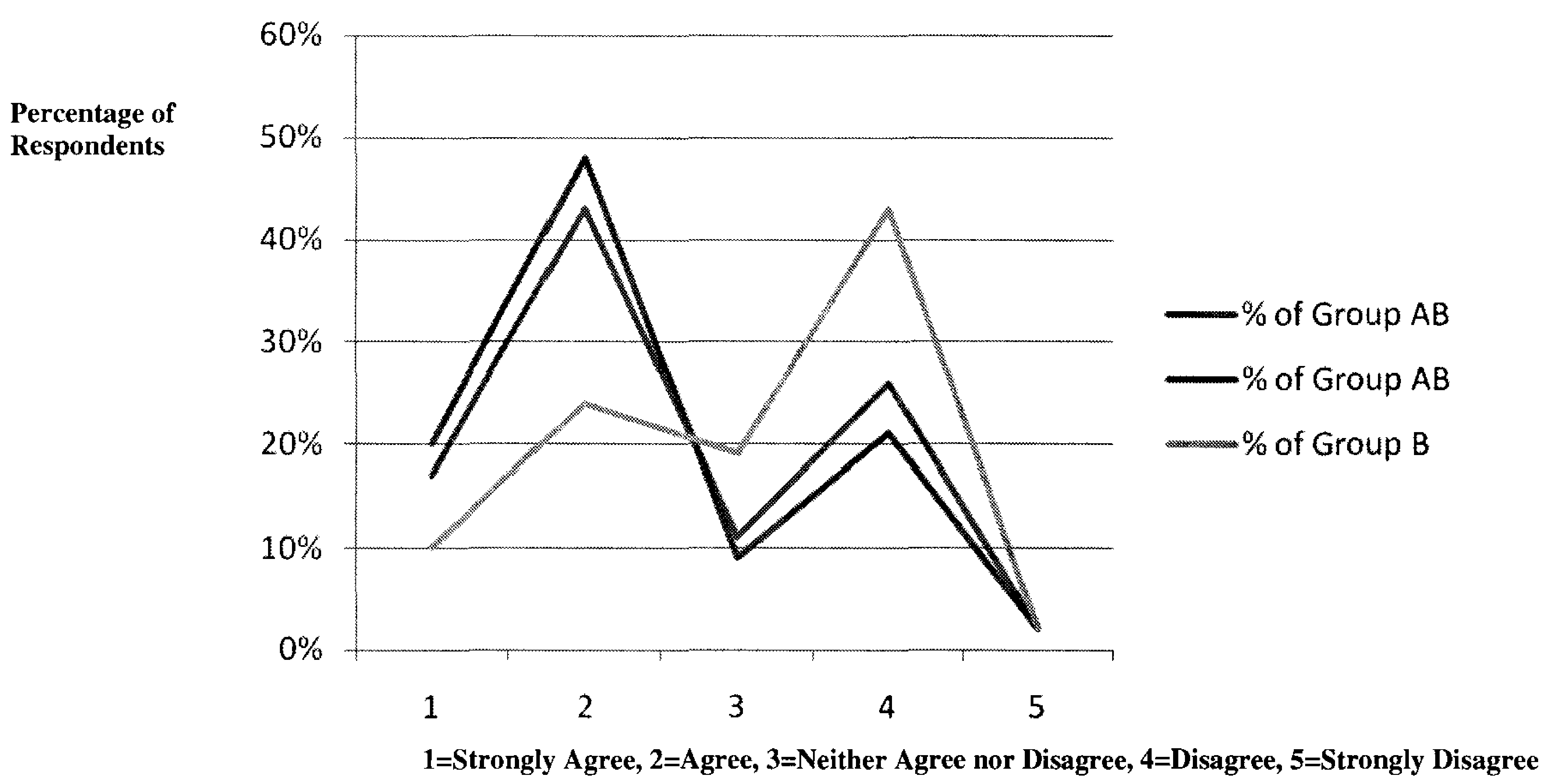




\section{CONCLUSIONS}

\section{ANSWERS TO RESEARCH QUESTIONS}

1. Do teachers generally believe that teacher evaluation affects teaching and learning?

From the survey answers, one could conclude that teachers see a relationship between teacher evaluation and teaching and learning. Group A was the control group in this survey, but the general findings of the survey bear mention as they apply to teaching. If the data in this study can be generalized, the results from group $\mathrm{AB}$ teachers suggest that teachers are satisfied with the evaluation programs in their schools. Perhaps this satisfaction could be attributed changes in the 1990s, when schools did a lot of rethinking about teacher and learning. With the arrival of NCLB great emphasis was placed on teacher quality. Therefore, policy makers and administrators revamped evaluation and even bought into programs like Pathwise. Also, great emphasis was placed on school improvement in an effort to erase achievement gaps. Schools restructured instruction, learning, instructional leadership, and teacher evaluation. This study reveals that teachers perceive teacher evaluation programs in general to be well-conceived and professionally executed. Teachers do, however, express concern that they are not as well-prepared as they should be for their classrooms on the first days of their careers in teaching. It is up to administration and teacher education programs to increase the self-efficacy of inductees so that they are successful. With teacher shortages looming and more and more bright teachers leaving the field after the first one or two years, it is vital to construct induction and mentoring programs that equip first year teachers for success. 


\section{Do teachers generally believe that professional development is needed or helpful to}

professional educators? Professional development would include teacher induction and ongoing (mid-career) professional development activities. Data in the survey suggest that teachers find these important, but that schools and districts need to improve these aspects of the teaching.

\section{Did the implementation of the standards-based teacher evaluation in the subject school} work to achieve the five goals previously noted? (Student learning, Instruction, Mentoring, Professional development, Collegiality) For the test group (Group B) this study reveals some important data. First of all, it reveals that the teacher evaluation system set up three years ago is still functioning, and it was an improvement over the old system. Generally, the teachers in the test school are very favorable in all aspects of the evaluation system, and though there is no quantitative evidence or pre-post protocol to validate improvement in perceptions, there is some anecdotal evidence to shows that instructional supervision and leadership have improved and that the teacher evaluation system was the catalyst of these steps forward for the test school.

Increasing Student Learning: Of the five goals for improving teacher evaluation in the test school, the first was student learning. How can a teacher evaluation system enhance student learning? The evaluation system can clarify the expectation to teachers that learning is the primary goal and then they will presumably place greater emphasis on the engagement and achievement of their charges. It is outside the bounds of this study if teacher evaluation has been a catalyst to improve student learning at the test school. Further research with a pre-post test protocol could measure the achievement gain raw scores and then correlate them to the teacher evaluation scores controlling for variables as 
other studies have done. Some states insist on including test scores in teacher evaluation and even offer monetary rewards to teachers whose students achieve desirable test scores, but improving teacher evaluation is only a part of the multi-dimensional matrix for improving student achievement. My proposition would be that large-scale improvements in instructional leadership—such as revamping the evaluation system--will eventually yield better teaching and learning in school.

Improving Instruction: The second goal of the new teacher evaluation system in the test school was to improve instruction. Judging from the responses of Group B to the questions like \#14 on the survey, the indication is that this goal is being reached. That is not to say that the previous evaluation system did not reach this goal, since there was no pre-treatment survey, but at least we know that the teachers' perceptions of the effectiveness of the system are on par with the rest of the respondents to this survey (group A).

Developing Mentoring: The third goal for the new evaluation system was mentoring. It appears from the survey data that mentoring (or teacher induction) has yet to develop and that the teacher evaluation system is not yet being utilized to inform a good induction program. With as many liberal arts (non-teacher education) graduates as the test school employs, it would be my strong recommendation that an administrator be assigned with a primary role of inducting new teachers, facilitating evaluation, and coordinating professional development. This would include more concentrated teacher training observation of new hires, requiring submission of reports, evaluation of tests, and creating lesson plans similar to what would be done in a student teaching module in a teacher education program. Perhaps a local university would grant college credit for the 
teachers who finish the first semester on-the-job internship, and this could be used to satisfy requirements for certification. The school owes this mentoring program to its new hires, its tuition-paying parents, and most of all to its students. After the first semester as new inductees have strengthened professionally, this administrator could become a teacher recruiter or serve another important administrative function in the school, such as leading secondary professional development.

Focusing Professional Development: The fourth goal of the new evaluation system was focusing professional development. The survey data certainly suggest that this goal has not been met at all. The evaluation system is an excellent way of identifying potential growth areas for teachers, but it appears that teacher perceive the professional development program to be unsatisfactory. One concern is that professional development activities are designed mostly for younger-level students, and since the test school is a $\mathrm{K}$ 12 school, more professional development activities help elementary teachers; however, my sample was from the secondary department only. Perhaps one problem in the test school has been the centralization of the professional development program. It is another recommendation that the administrator who leads the induction program also work with the entire secondary faculty or organize and coordinate individual professional development and that the professional development program be supervised, but independent. One district in California believes that "because teachers have different needs and learning styles, tenured teachers ... choose from ... three different formats for professional growth." The district "believes that the effort required to empower teachers to direct their own professional development, to investigate how particular teaching skills impact student learning, and to monitor and assess their own professional growth in 
collaboration with their colleagues and administrators is both valuable and necessary."10

Supervised yet self-directed professional development is one option for career teachers, but administrators can mandate probationary or teachers with improvement plans to expand their knowledge as necessary. If the formative evaluations reveal pedagogical weaknesses, then the teacher should be willing to take a class or attend a conference where he can be trained for targeted skills. Secondary teachers are usually more interested in learning more about their subjects, but they must be willing to grow as professional educators as well, and this requires more than just deeper content knowledge. The added benefit to getting pedagogical training-as well as subject matter knowledge - is that the teacher is then more qualified and makes himself more marketable while benefitting his students.

Facilitating Collegiality: The fifth goal of implementing the standardized teacher evaluation system at the test school was to improve collegiality among the administration and the faculty. As professional educators it is vital to discuss our own strengths and weaknesses in an environment where growth is key and our jobs are not always on the line. Reflection on experience can yield growth. As colleagues, educators can foster a stronger community of learning that is contagious to students. Student, teachers, and administrators all make errors, and if we are willing to dialogue collegially about mistakes and about triumphs, we can overcome weakness that may make us prone to mistakes and we can learn how to achieve better results. Reflecting and discussing successes can help teachers to grow and to be encouraged. These were some reasons that the members of the administration and departmental leadership implemented a more collegial evaluation system. From the responses to the survey, there appears to be mixed 
success in this goal. Teachers still generally appear uncomfortable with the idea of constant observation and supervision, but they do perceive that they have input into their evaluations, indicating that they appreciate the pre-observation and post-observation conferences. Teachers also generally perceive that they are growing professionals who need dialogue, encouragement, community, development, and criticism to achieve the worthy goals of training students to maximize their potential.

4. Is there a difference between the teachers' perceptions of teacher evaluation in the general population compared to the perceptions of teachers in the subject school?

Generally, the null hypothesis was valid since there was little difference between perceptions of teacher evaluation programs in group A and group B. To some this may come as a surprise, but it is hoped that the perceptions have improved since the new evaluation system was implemented three years ago, a system that most agreed was woefully inadequate. Perhaps implementation of the standards-based teacher evaluation system at the test brought the school up to "industry standard."

5. Are efforts to link teacher evaluation and professional development improving teacher perceptions of teacher evaluation and professional development programs? Data from this survey strongly indicate that teachers in the test school have negative perceptions of professional development programs and that professional development goals are not adequately being linked to teacher evaluation. 


\section{ENDNOTES}

Chapter 1

1. Marshall, K. It's time to rethink teacher supervision and evaluation. Phi Delta Kappan, $86: 10,(2005), 731$.

2. Milanowski, A. T., and Heneman, H. G.,III. Assessment of teacher reactions to a standards-based teacher evaluation system: A pilot study. Journal of Personnel Evaluation in Education, 15:3, (2001), 194.

3. Xu, S., Teacher evaluation and student learning: Perceptions of elementary school principals and teachers. Doctoral diss., University of Massachusetts Amherst. (2001), 11.

4. Milanowski, A. T., and Heneman, H. G.,III. Assessment of teacher reactions to a standards-based teacher evaluation system: A pilot study. Journal of Personnel Evaluation in Education, 15:3, (2001), 197.

5. Peterson, K., Research on school teacher evaluation. NASSP Bulletin, 88:639, (2004), 74. (His references)

6. Odden, A. Lessons learned about standards-based teacher evaluation systems. Peabody Journal of Education. 79:4, (2004), 127.

7. Marshall, K. It's time to rethink teacher supervision and evaluation. Phi Delta Kappan, $86: 10,(2005), 730$.

8. Ibid.

9. Brown, G. Guiding faculty to excellence: Instructional supervision in the Christian school. $2^{\text {nd }}$ ed. Colorado Springs: Purposeful Design Pub., (2002), 1-12. 
10. Odden, A. Lessons learned about standards-based teacher evaluation systems. Peabody Journal of Education. 79:4, (2004), 128-9.

\section{Chapter 4}

1. Mo, K. W., Conners, R., \& McCormick, J. Teacher appraisal in Hong Kong selfmanaging secondary schools: Factors for effective practices. Journal of Personnel Evaluation in Education, 12:1,(1998) 24.

2. Chow, A. P. Y., Wong, E. K. P., Yeung, A. S., \& Mo, K. W. Teachers' perceptions of appraiser-appraisee relationships. Journal of Personnel Evaluation in Education, $16: 2,(2002) 85-101$.

3. Xu, S., Teacher evaluation and student learning: Perceptions of elementary school principals and teachers. Doctoral diss., University of Massachusetts Amherst. (2001), 10.

4. Ibid., 11

5. Kimball, S. M. Analysis of feedback, enabling conditions and fairness perceptions of teachers in three school districts with new standards-based evaluation systems. Journal of Personnel Evaluation in Education, 16:4, (2002) 257.

6. Davis, D. R., Ellett, C. D., \& Annunziata, J. Teacher evaluation, leadership and learning organizations. Journal of Personnel Evaluation in Education, 16:4, (2002). 298.

7. Marshall, K. It's time to rethink teacher supervision and evaluation. Phi Delta Kappan, $86: 10,(2005), 727$.

8. Milanowski, A. T., and Heneman, H. G.,III. Assessment of teacher reactions to a 
standards-based teacher evaluation system: A pilot study. Journal of Personnel Evaluation in Education, 15:3, (2001), 207.

9. Ellett, C. D., Annunziata, J., \& Schiavone, S. Web-based support for teacher evaluation and professional growth: The professional assessment and comprehensive evaluation system (PACES). Journal of Personnel Evaluation in Education, 16:1, (2002), 63-74.

10. Donaldson, C. Teacher evaluation: A self-directed, inquiry-based approach. Thrust for Educational Leadership, 29:3, (2000), 30. 


\section{REFERENCES}

Alleman, J. (2006) Links between teacher evaluation/supervision and student

achievement: A case study of a successful urban elementary school. (Ed.D.

Dissertation, University of Southern California) Retrieved November 2, 200 from Proquest Dissertations and Theses.

Archibald, S. (2007) How well do standards-based teacher evaluation scores identify high-quality teachers? A multilevel, longitudinal analysis of one district. (Ph.D. Dissertation. University of Wisconsin--Madison) Retrieved November 2, 2007 from Proquest Dissertations and Theses.

Ballou, D. et al (2004) Controlling for student background in value-added assessment of teachers. Journal of Educational and Behavioral Statistics, 29(1) 37-66.

Barnett, B., Hopkins-Thompson, P., Hoke, M., \& Southeast Center for Teaching Quality, Chapel Hill, NC. (2002). Assessing and supporting new teachers. lessons from the Southeast. Teaching quality in the Southeast policy brief. Retrieved June 21, 2005, ERIC Document Retrieval Service (ED 474 183)

Bastarache, \& Arthur, R. (2000). Purposes, methods and effectiveness of teacher evaluation: Perceptions of urban elementary teachers and principals. (Dissertation, University of Massachusetts Lowell). Retrieved June 25, 2005, Dissertation Abstracts.

Beerens, D. R. (2000). Evaluating teachers for professional growth : Creating a culture of motivation and learning. Thousand Oaks, Calif.: Corwin Press.

Bernstein, E. (2004) What teacher evaluation should know and be able to do. NASSP Bulletin, 88(639) 80-88. 
Black, S. (2004). Teachers can engage disengaged students. The Education Digest, 69(7), $39-44$.

Blanton, L. P. (2006. Summer) Models and measures of beginning teacher quality. Journal of Special Education, 40(2), 115-127 Retrieved November 1, 2007 from EBSCOhost.

Bouchamma, Y. (2005) Evaluating teaching personnel. Which model of supervision do Canadian teachers prefer? Journal of Personnel Evaluation in Education. 18(4) 289308. Retrieved November 24, 2004 from ABI/INFORM Global.

Bourff, \& Blane, A. (1994). The relationship between teacher evaluation procedures, effective teaching practices, and student performance. (Doctoral dissertation, Indiana University). Retrieved June 25, 2005, Dissertation Abstracts.

Bracey, G. (2004) Research: Serious questions about the Tennessee value-added system. Phi Delta Kappan. 85(9) 716

Brown, G. (2002) Guiding faculty to excellence: Instructional supervision in the Christian school. ( $2^{\text {nd }}$ ed.) Colorado Springs: Purposeful Design Pub.

Buck, S., \& Tiene, D. (1989). The impact of physical attractiveness, gender, and teaching philosophy on teacher evaluations. Journal of Educational Research, 82(3)

Campbell, J. et al. (2004) Assessing teacher effectiveness: developing a differentiated model. London, UK: Routledge Falmer P.

Castor, B. (2002). Better assessment for better teaching. Education Week, 22(15), 28-30.

Chow, A. P. Y., Wong, E. K. P., Yeung, A. S., \& Mo, K. W. (2002). Teachers' perceptions of appraiser-appraisee relationships. Journal of Personnel Evaluation in Education, 16(2), 85-101. Retrieved November 23, 2004, from ABI/INFORM 


\section{Global.}

Chow, A. P., Wong, E. K., Yeung, A. S., \& Mo, K. W. (2001). Appraisal of teachers: who appraises whom and does it matter? Journal of Personnel Evaluation in Education. Retrieved November 23, 2004, from ABI/INFORM Global.

Coker, H. (1985). A study of the correlation between principals' ratings of teacher effectiveness and pupil growth. Retrieved June 29, 2005, ERIC Document Retrieval Service (ED 259 460)

Conley, S. (2005) Standards-based evaluation and teacher career satisfaction: a structural equation modeling analysis. Journal of Personnel Evaluation in Education 18(1), 67-77.

Cruickshank, D. R. \& Haefele, D. (2001). Good teachers, plural. Educational Leadership, $58(5), 26-30$.

Danielson, C. (1996). Enhancing professional practice: A framework for teaching.

Alexandria,VA: Association of Supervision and Curriculum Development. . (2001). New trends in teacher evaluation. Educational Leadership,

$58(5), 12-15$. . (2005). Strengthening the school's backbone. Journal of Staff

Development, 26(2), 34-37.

Danielson, C., \& McGreal, T. L. (2000). Teacher evaluation to enhance professional practice. Alexandria,VA: Association for Supervision and Curriculum Development and Princeton, NJ: Educational Testing Service.

Darling-Hammond, L. (1997). Quality teaching: The critical key to learning. Principal, 77, 5-6+. Retrieved June 30, 2005, Professional Development Collection. 
Darling-Hammond, L. \& Falk, B. (1997). Using standards and assessments to support student learning. Phi Delta Kappan, 79, 190-199. Retrieved June 30, 2005, Professional Development Collection.

Davis, D. R., Ellett, C. D., \& Annunziata, J. (2002). Teacher evaluation, leadership and learning organizations. Journal of Personnel Evaluation in Education, 16(4), 287301. Retrieved November 23, 2004, from ABI/INFORM Global.

Donaldson, C. (2000). Teacher evaluation: A self-directed, inquiry-based approach. Thrust for Educational Leadership, 29(3), 30. Retrieved June 29, 2005, Educational Abstracts.

Dyer, K. M. (2001). The power of 360-degree feedback. Educational Leadership, 58(5), $35-38$.

Educational Testing Service. (2004). PATHWISE framework observation progam: Program resource manual. Princeton, NJ: Educational Testing Service.

Egelson, P., McColskey, W., \& SERVE: SouthEastern Regional Vision for Education. (1998). Teacher evaluation: The road to excellence. current findings on teacher evaluation models that support professional growth. sharing success. Retrieved November 24, 2004, ERIC Document Retrieval Service ED 446 063).

Ellett, C. D., Annunziata, J., \& Schiavone, S. (2002). Web-based support for teacher evaluation and professional growth: The professional assessment and comprehensive evaluation system (PACES). Journal of Personnel Evaluation in Education, 16(1), 63-74. Retrieved November 24, 2004, ABI/INFORM Global.

Fischer, L., Schimmel, D., \& Stellman, L. (2003). Teachers and the law. $6^{\text {th }}$ ed. Retrieved June 21, 2005, ERIC Document Retrieval Service (ED 482 625) 
Gallagher, H. A. (2004). Vaughn elementary's innovative teacher evaluation system: Are teacher evaluation scores related to growth in student achievement? PJE.Peabody Journal of Education, 79(4), 79-107. Retrieved June 21, 2005, from the Professional Development Collection database.

Glickman, C. D., Gordon, S. P., \& Ross-Gordon, J. M. (2004). Supervision and instructional leadership : A developmental approach (6th ed.). Boston, MA: Allyn and Bacon.

Goldrick, L., \& National Governors'Association, Washington,DC.Center for Best Practices. (2002). Improving teacher evaluation to improve teaching quality. issue brief. Retrieved June 21, 2005, ERIC Document Retrieval Service (ED 480 159).

Goldstein, J. (2007) Easy to dance to: solving problems of teacher evaluation with peer assistance and review. American Journal of Education. 113:(3), 479-508.

Grover, R., \& Bernstein, A. (2005). Arnold gets strict with the teachers. Business Week, (3931), 84-85.

Heneman, H., and Milanowski, A. (2003) Continuing assessment of teacher reactions to a standards-based teacher evaluation system. Journal of Personnel Evaluation in Education. 17(2), 173-195.

Heneman, H. et al. (2006) Standards-based teacher evaluation as a foundation for knowledge and skill-based pay. CPRE Policy Briefs (RB-45). Consortium for Policy Research in Education. Retrieved from ERIC (ED 493 116).

Hill, D. (2000). He's got your number. Teacher Magazine, 11(8), $42-47$.

Holtzapple, E.(2003) Criterion-related validity evidence for a standards-based teacher evaluation system. Journal of Personnel Evaluation in Education. 17:3, 207-219. 
Howard, B. B., \& McColskey, W. H. (2001). Evaluating experienced teachers. Educational Leadership, 58(5), 48-51.

Hutto, J. \& Dean, R. (2001). Teacher evaluation and development and student performance. (Doctoral dissertation, The University of Texas at Austin). Retrieved June 28, 2005, Dissertation Abstracts.

Iwanicki, E. F. (2001). Focusing teacher evaluations on student learning. Educational Leadership, 58(5), 57-59.

Johnston, R. C. (1999). Greater expectations. Education Week, 18(17), 177.

Keller, B. (2004). States receive poor marks for teacher-quality standards. Education Week, 23(32), 21-21.

Kellor, E. (2005) Catching up with the Vaughn express: Six years of standards-based teacher evaluation and performance pay. Education Policy Analysis Archives. 13(7).

Kersten, T and Israel, M (2005) Teacher evaluation: principals' insights and suggestions for improvement. Planning and Changing. 36(1), 47-67. Retrieved 1 November 2007 from ProQuest.

Kimball, S. M. (2002). Analysis of feedback, enabling conditions and fairness perceptions of teachers in three school districts with new standards-based evaluation systems. Journal of Personnel Evaluation in Education, 16(4), 241-268. Retrieved November 24, 2004, ABI/INFORM Global.

Kimball, S. M., White, B., Milanowski, A. T., \& Borman, G. (2004). Examining the relationship between teacher evaluation and student assessment results in Washoe county. PJE.Peabody Journal of Education, 79(4), 54-78. Retrieved June 21, 2005, 
from the Professional Development Collection database.

Kimball, S. M., \& Miller, S. (2001). Innovations in teacher evaluation: Case studies of two school districts with teacher evaluation systems based on the framework for teaching. (Doctoral dissertation, The University of Wisconsin - Madison). Retrieved June 24, 2005. Dissertation Abstracts.

Kimball, S. M., Milanowski, T., and Heneman, H. (2007) Standards-based teacher evaluation: What have we learned? (PowerPoint presentation at the CPRE Invitational Conference: New Approaches to School Finance, School Improvement and Teacher Compensation: Fifteen Years of Research and Policy Development, Chicago, IL., Feb. 21-22, 2007) cpre.wceruw.org/conference/feb07/presentations/ kimballhenemanmilanowski022207AM.ppt.

King, \& Marie, L. (2003). Teacher perceptions of the Danielson/McGreal model of differentiated evaluation and its impact on professional growth. (Doctoral dissertation, Seton Hall University, College of Education and Human Services). Retrieved June 24, 2005. Dissertation Abstracts

Kupermintz, H. et al (2001) Teacher effects as a measure of teacher effectiveness: Construct validity considerations in TVAAS (Tennessee Value-Added Assessment System). Retrieved from ERIC (ED 458 295).

Lee, K. S. Y. (2002). Teacher evaluation for promoting teaching and learning: A blueprint for general and special education. Asia-Pacific Journal of Teacher Education \& Development, 5(1), 77-92.

Lester, J. B., \& Grant, C. M. (2001). Mathematics supervision through a new lens. Educational Leadership, 58(5), 60-63. 
Loucks, \& Barker, S. (2000). High school principals' perception of the usefulness of teacher evaluation for school improvement. (Doctoral dissertation, University of the Pacific). Retrieved June 28, 2005 from Disseration Abstracts.

Lydia, J. (1984). The relationship between teacher evaluation and student academic achievement (Doctoral Dissertation, University of Northern Colorado, Dept. of Educational Administration). Retrieved June 28, 2005 from Dissertation Abstracts.

Maranzano, C. (2000). Music teacher performance evaluation: A call for more inclusive models. Journal of Personnel Evaluation in Education, 14(3), 267-274. Retrieved November 24, 2004. ABI/INFORM Global.

Marshall, K. (2005). It's time to rethink teacher supervision and evaluation. Phi Delta Kappan, 86(10), 727-735. Retrieved June 26, 2005. Education Abstacts.

McCollum, S. (2001). How merit pay improves education. Educational Leadership, 58(5), 21-24.

McColskey, W., Egelson, P., \& Southeastern Regional Vision for Education (SERVE), Tallahassee,FL.(1997). Designing teacher evaluation systems that support professional growth. 2nd Edition. Retrieved November 26, 2005. ERIC Document Retrieval Service (ED 408 287).

McGee, C. D., \& Imbeau, M. B. (2001). A framework for evaluating intern teachers. Catalyst for Change, 31(1), 5-8.

Medley, D. M., \& Coker, H. (1987). The accuracy of principals' judgments of teacher performance. Journal of Educational Research. 80(4), 242-7. (1987). How walid are principals' judgments of teacher effectiveness? Phi Delta Kappan 69(2), 138-140. 
Milanowski, A. T. (2004). The relationship between teacher performance evaluation scores and student achievement: Evidence from Cincinnati. PJE.Peabody journal of education, 79(4), 33-53. Retrieved June 21, 2005, from the Professional Development Collection database. (2005) Split roles in performance evaluation--A field study involving new teachers. Journal of Personnel Evaluation in Education. 18(4), 153-169. Milanowski, A. T., \& Heneman, H. G.,III. (2001). Assessment of teacher reactions to a standards-based teacher evaluation system: A pilot study. Journal of Personnel Evaluation in Education, 15(3), 193-212.

Millman, J. (1997). Grading teachers, grading schools : Is student achievement a valid evaluation measure?. Thousand Oaks, Calif.: Corwin Press.

Mo, K. W., Conners, R., \& McCormick, J. (1998). Teacher appraisal in Hong Kong selfmanaging secondary schools: Factors for effective practices. Journal of Personnel Evaluation in Education, 12(1), 19-42.

Murphy, A., \& Rose, N. (1993). A comparative study of student achievement relative to teacher behavior as influenced by a state model for local evaluation. (Doctoral dissertation, Peabody College for Teachers of Vanderbilt University). Retrieved June 28, 2005. Dissertation Abstracts.

Nathan, L. (2005) The art of evaluation and professional development. Principal Leadership 6(1), 32. Retrieved 1 November 2007 from ProQuest.

Nolan, J. (2007) Teacher supervision and evaluation: theory into practice. $2^{\text {nd }}$ ed. New York: Wiley.

Nougaret, A. A., Mastropieri, M. A., \& Scruggs, T. E. (2005). Does teacher education 
produce better special education teachers? Exceptional Children, 71(3), 217-229.

Odden, A. (2004) Lessons learned about standards-based teacher evaluation systems. Peabody Journal of Education. 79(4), 126-137.

Olina, Z., \& Sullivan, H. J. (2004). Student self-evaluation, teacher evaluation, and learner performance. Educational Technology Research \& Development, 52(3), 522. Retrieved June 21, 2005, from the Professional Development Collection database.

Painter, B. (2001). Using teaching portfolios. Educational Leadership, 58(5), 31-34.

Peterson, K. D. (2000). Teacher evaluation : A comprehensive guide to new directions and practices (2nd ed.). Thousand Oaks, Calif.: Corwin Press. , (2004) Research on school teacher evaluation. NASSP Bulletin, 88(639), 60-79.

Peterson, K. D., Kelley, P., \& Caskey, M. (2002). Ethical considerations for teachers in the evaluation of other teachers. Journal of Personnel Evaluation in Education, 16(4), 317-324.

Peterson, K. D., Wahlquist, C., Bone, K., Thompson, J., \& Chatterton, K. (2001). Using more data sources to evaluate teachers. Educational Leadership, 58(5), 40-43.

Peterson, K. et al (2005) Effective teacher evaluation: a guide for principals. New York: Corwin Press.

Pool, C. R. (2001). Evaluating educators. Educational Leadership, 58(5), 96.

Pool, J. E, et al. (2001) How valid are the National Board of Professional Teaching Standards assessments for predicting the quality of actual classroom teaching and learning? Journal of Personnel Evaluation in Education 15(1): 31-48. 
Ramirez, A. (2001). How merit pay undermines education. Educational Leadership, $58(5), 16-20$.

Rapp, L. J. (2003). Impact of the Danielson model of evaluation on teacher perceptions in the Greenon local school district. (Thesis, Wright State University) Retrieved June 25, 2005. Dissertation Abstracts.

Reddehopp, T. (2007) Linking the teacher appraisal process to the school improvement plan. Principal Leadership, 7(6), 40-43.

Reid, K. S. (2002). Study tracks Cincinnati's new teacher ratings, test scores. Education Week, 2l(29), 9.

Sanders, W. L. (1998). Value-added assessment. School Administrator, 11(55), 24-27.

Schumacher, N. L. (2003). The development and implementation of a multifaceted model for differentiated teacher evaluation to improve student achievement (Thesis: Rowan University) Retrieved June 25, 2005. Dissertation Abstracts.

Schumacher, \& T, G. (2004). Perceptions of the impact of a standards-based teacher evaluation system, based on the Danielson "Framework for Teaching" model, on teaching and student learning. (Doctoral dissertation, The University of Wisconsin Madison). Retrieved June 26, 2005. Dissertation Abstracts.

Shinkfield, A. J., and Stufflebeam, D. L..(1995). Teacher evaluation: Guide to effective practice. evaluation in education and human services. Kalamazoo,MI: Center for Research in Educational Accountability and Teacher Evaluation (CREATE). Retrieved November 23, 2004. ERIC Document Retrieval Service (ED 435 632). Smith, \& Henrique, B. (1993). An assessment of hunter's model on teacher evaluations of the model, supervisor ratings, instructional strategies, and student achievement. 
(Doctoral dissertation, Seton Hall University, School of Education). Retrieved June 26, 2005. Dissertation Abstracts.

Snyder, J. (2001). The New Haven Unified School District: A teaching quality system for excellence and equity. Journal of personnel evaluation in education, 15(1), 61-81.

Soar, R. S., Medley, D. M., \& Coker, H. (1983). Teacher evaluation: A critique of currently used methods. Phi Delta Kappan, 65(4), 239-246.

St. Maurice, H., \& Shaw, P. (2004). Teacher portfolios come of age: A preliminary study. NASSP Bulletin, 88, 15-25.

Statistical primer for psychology students (2001). McGraw-Hill Higher Education.

Retrieved July 1, 2005, from http://www.mhhe.com/socscience/intro/cafe/common stat/index.mhtml.

Stronge, J. H. (1997). Evaluating teaching : A guide to current thinking and best practice. Thousand Oaks, Calif.: Corwin Press.

Stronge, J. H., \& Tucker, P. D. (1999). The politics of teacher evaluation: A case study of new system design and implementation. Journal of Personnel Evaluation in Education, 13(4), 339-359. . (2000). Teacher evaluation and student achievement. student assessment series. Washington, DC: National Education Association. . (2003). Handbook on teacher evaluation : Assessing and improving performance. Larchmont, N.Y.: Eye On Education.

Sweeley, \& M, T. (2004). Teachers' attitudes towards Charlotte Danielson's four domains of teacher evaluation. (Doctoral dissertation, Widener University). Retrieved June 29, 2005. Dissertation Abstracts. 
Takakura, S., \& Ono, Y. (2001). Restructuring teacher evaluation in Japan: recent developments in personnel management system. Retrieved June 21, 2005, ERIC Document Retrieval System (ED 477 498).

Tucker, P. D., \& Stronge, J. H. (2001). Measure for measure: Using student test results in teacher evaluations. American School Board Journal, 188(9), 34-37.

Tucker, P. D., Stronge, J. H., \& Gareis, C. R. (2002). Handbook on teacher portfolios for evaluation and professional development. Larchmont, NY: Eye on Education.

Tucker, P. D., Stronge, J. H., \& NetLibrary, I. (2005). Linking teacher evaluation and student learning. Alexandria, VA: Association for Supervision and Curriculum.

Whaley, J., Ed, \& Cox, C., Ed. (2002). Developing the effective teacher: Hiring, evaluation, and retention practices for the school administrator. Retrieved June 21, 2005 ,

$\mathrm{Xu}$, S. (2001). Teacher evaluation and student learning: Perceptions of elementary school principals and teachers. (Doctoral dissertation, University of Massachusetts Amherst). Retrieved June 29, 2005. Dissertation Abstracts.

Xu, S and Sinclair, R.L. (2002, April) Improving teacher evaluation for increasing student learning. Paper presented at the annual meeting of the American Educational Research Association, New Orleans, LA. ERIC Document Retrieval Service ED 469164.

Zimmerman, S., \& Deckert-Pelton, M. (2003). Evaluating the evaluators: Teachers' perceptions of the principal's role in professional evaluation. NASSP Bulletin, 87(636), 28-37. 


\title{
APPENDIX A \\ Standards-Based Teacher Evaluation System for Test School
}

\author{
School Name \\ Secondary Teacher Evaluation System
}

Based on Charlotte Danielson's Enhancing Professional Practice: A Framework for Teaching (1996, ASCD) and the Praxis III: Classroom Performance Assessment

\section{Framework}

The framework that follows divides components of professional teacher performance into four domains of six to nine components each. Each of the components is then divided into two to five elements.

Domain I: Planning and Preparation

Component 1a: Demonstrating Knowledge of Content and Pedagogy

Component 1b: Demonstrating Knowledge of Students

Component 1c: Selecting Instructional Goals

Component 1d: Demonstrating Knowledge of Resources

Component 1e: Designing Coherent Instruction

Component 1f: Assessing Student Learning

Domain II: Classroom Environment

Component 2a: Creating an Environment of Respect and Rapport

Component 2b: Establishing a Culture for Learning

Component 2c: Managing Classroom Procedures

Component 2d: Managing Student Behavior

Component 2e: Organizing Physical Space

Component 2f: Ministering to Students

Domain III: Instruction

Component 3a: Communicating Clearly and Accurately

Component 3b: Using Questioning and Discussion Techniques

Component 3c: Engaging Students in Learning

Component 3d: Providing Feedback to Students

Component 3e: Demonstrating Flexibility and Responsiveness

Component 3f: Biblical Worldview Integration

Domain IV: Professional/Ministry Responsibilities

Component 4a: Modeling a Christ-centered Lifestyle

Component 4b: Reflecting on Teaching

Component 4c: Communicating with Families

Component 4d: Contributing to the School

Component 4e: Following Christian Principles in Relationships

Component 4f: Growing and Developing Professionally

Component 4g: Growing and Developing in Discipleship

Component 4h: Showing Professionalism

Component 4i: Maintaining Accurate Records 


\section{Sources of Information}

The following sources would be used for teacher evaluation. The teacher is responsible to present a portfolio of informational sources:

- Classroom Observations (Administrative and department head)

- Teacher Self-Evaluation and Reflection (self-evaluation and reflection)

- Planning Documents (plan book, lesson plans, assignment sheets, unit plans, schedules and syllabi)

- Teaching Artifacts (teacher-constructed tests, worksheets, Lessons, graded work, student performances, social contract)

- Teacher-maintained records (grade book, attendance book, discipline log)

- Parent and Student Communications (surveys, notes to and from parents, notes to and from students, logs of parent contacts, notes from parent conferences.)

- Professional Development Activities (projects from teacher ed. classes, notes from seminars taught or taken at convention, organizational notes for activities the teacher has sponsored, published articles)

\begin{tabular}{|c|c|}
\hline Components of Evaluation & Primary Sources of Information \\
\hline $\begin{array}{l}\text { Domain I: Planning and Preparation } \\
\text { 1a: Knowledge of Content and Pedagogy } \\
\text { 1b: Demonstrating Knowledge of Students } \\
\text { 1c: Selecting Instructional Goals } \\
\text { 1d: Demonstrating Knowledge of Resources } \\
\text { 1e: Designing Coherent Instruction } \\
\text { 1f: Assessing Student Learning }\end{array}$ & $\begin{array}{l}\text { Classroom Observation, Unit Plan, Lesson Plan } \\
\text { General Observation, Interview } \\
\text { Plan Book, Sample Lesson Plan, Teaching Artifact, Syllabus } \\
\text { Lesson Plan, General Observation, Classroom Observation } \\
\text { Plan book, Lesson Plan, Unit Plan, Teaching Artifact } \\
\text { Plan book, Lesson Plan, Tests or Alternative Assessments, Teaching } \\
\text { Artifacts }\end{array}$ \\
\hline $\begin{array}{l}\text { Domain II: Classroom Environment } \\
\text { 2a: Creating an Environment of Respect and Rapport } \\
\text { 2b: Establishing a Culture for Learning } \\
\text { 2c: Managing Classroom Procedures } \\
\text { 2d: Managing Student Behavior } \\
\text { 2e: Organizing Physical Space } \\
\text { 2f: Ministering to Students }\end{array}$ & $\begin{array}{l}\text { Classroom Observation, Student Feedback, Parent Feedback } \\
\text { Classroom Observation, Teaching Artifact, Student Feedback } \\
\text { Classroom Observation, Self-Evaluation } \\
\text { Classroom Observation, Discipline Log, Referrals } \\
\text { Classroom Observation } \\
\text { Self-Evaluation, General Observation }\end{array}$ \\
\hline $\begin{array}{l}\text { Domain III: Instruction } \\
\text { 3a: Communicating Clearly and Accurately } \\
\text { 3b: Using Questioning and Discussion Techniques } \\
\text { 3c: Engaging Students in Learning } \\
\text { 3d: Providing Feedback to Students } \\
\text { 3e: Demonstrating Flexibility and Responsiveness } \\
\text { 3f: : Teaching Spiritual Truth/Christian Worldview }\end{array}$ & $\begin{array}{l}\text { Classroom Observation } \\
\text { Classroom Observation } \\
\text { Classroom Observation, Teaching Artifacts, Student Work } \\
\text { Classroom Observation, Graded Work } \\
\text { Classroom Observation, General Observation } \\
\text { Classroom Observation, Lesson plans }\end{array}$ \\
\hline $\begin{array}{l}\text { Domain IV: Professional Responsibilities } \\
\text { 4a: Modeling a Christ-centered Lifestyle } \\
\text { 4b: Reflecting on Teaching } \\
\text { 4c: Communicating with Families } \\
\text { 4d: Contributing to the School } \\
\text { 4e: Following Christian Principles in Relationships } \\
\text { 4f: Growing and Developing Professionally } \\
\text { 4g: Growing and Developing in Discipleship } \\
\text { 4h: Showing Professionalism } \\
\text { 4i: Maintaining Accurate Records }\end{array}$ & $\begin{array}{l}\text { General Observation; Self-Evaluation } \\
\text { Self-Evaluation, Reflection Form } \\
\text { Letters to Parents, Parent Night Hand-out, Conference forms } \\
\text { General Observation, Attendance Records } \\
\text { Self-Evaluation; General Observation } \\
\text { Work from Classes Taken, Logs of Personal Goals, Copies of Conference } \\
\text { Programs, Copies of Writings General Observation, } \\
\text { Self-Evaluation } \\
\text { General Observation } \\
\text { Attendance Book, Grade Book, Sign-Out Forms }\end{array}$ \\
\hline
\end{tabular}




\section{Domain I: Planning and Preparation}

\begin{tabular}{|c|c|c|c|c|}
\hline \multicolumn{5}{|c|}{ Component 1a: Demonstrating Knowledge of Content and Skill in Teaching Subject (back to framework) } \\
\hline \multirow[b]{2}{*}{ Element } & \multicolumn{4}{|c|}{ Level of Performance } \\
\hline & Unsatisfactory & Basic & Proficient & Distinguished \\
\hline $\begin{array}{l}\text { Knowledge of } \\
\text { Content }\end{array}$ & $\begin{array}{l}\text { Teacher has weak } \\
\text { command of subject } \\
\text { matter. Teacher makes } \\
\text { frequent errors or does } \\
\text { not correct errors } \\
\text { students make. }\end{array}$ & $\begin{array}{l}\text { Teacher displays basic } \\
\text { content knowledge of his } \\
\text { or her discipline but } \\
\text { generally does not } \\
\text { articulate connection } \\
\text { with other parts of the } \\
\text { discipline or with other } \\
\text { disciplines. }\end{array}$ & $\begin{array}{l}\text { Teacher displays solid } \\
\text { content knowledge and } \\
\text { frequently makes } \\
\text { connections between } \\
\text { the content and other } \\
\text { parts of the discipline } \\
\text { and other disciplines }\end{array}$ & $\begin{array}{l}\text { Teacher displays extensive } \\
\text { content knowledge, with } \\
\text { evidence of continuing pursuit } \\
\text { of such knowledge. }\end{array}$ \\
\hline $\begin{array}{l}\text { Teaching Skill } \\
\text { in Subject } \\
\text { Area }\end{array}$ & $\begin{array}{l}\text { Teacher does not have } \\
\text { skills necessary to teach } \\
\text { subject effectively and } \\
\text { displays little } \\
\text { understanding of } \\
\text { instructional issues } \\
\text { involved in student } \\
\text { learning of the content. } \\
\text { Teacher does not } \\
\text { attempt to strengthen his } \\
\text { own teaching skills }\end{array}$ & $\begin{array}{l}\text { Teacher displays basic } \\
\text { teaching skill and knows } \\
\text { basically how to teach his } \\
\text { or her subject. Teacher } \\
\text { makes some attempts to } \\
\text { strengthen his or her } \\
\text { teaching skills. Teacher } \\
\text { rarely anticipates } \\
\text { students' misconceptions. }\end{array}$ & $\begin{array}{l}\text { Teacher has developed } \\
\text { a wide repertoire of } \\
\text { effective teaching } \\
\text { methods within his or } \\
\text { her subject area. } \\
\text { Teacher has strong } \\
\text { understanding of best } \\
\text { teaching practices. } \\
\text { Teacher sometimes } \\
\text { anticipates student } \\
\text { misconceptions. }\end{array}$ & $\begin{array}{l}\text { Teacher possesses an } \\
\text { extraordinary repertoire of } \\
\text { effective teaching methods } \\
\text { within his or her subject area. } \\
\text { Teacher displays wide } \\
\text { understanding of best teaching } \\
\text { practices and frequently } \\
\text { anticipates student } \\
\text { misconceptions. Teacher take } \\
\text { leadership in sharing skills with } \\
\text { other teachers. }\end{array}$ \\
\hline
\end{tabular}

\begin{tabular}{|c|c|c|c|c|}
\hline \multicolumn{4}{|c|}{ Component 1b: Demonstrating Knowledge of Students } & (back to framework) \\
\hline \multirow[b]{2}{*}{ Element } & \multicolumn{4}{|c|}{ Level of Performance } \\
\hline & Unsatisfactory & Basic & Proficient & Distinguished \\
\hline $\begin{array}{l}\text { Characteristics } \\
\text { of Age Group }\end{array}$ & $\begin{array}{l}\text { Teacher displays } \\
\text { minimal knowledge of } \\
\text { developmental } \\
\text { characteristics of age } \\
\text { group. }\end{array}$ & $\begin{array}{l}\text { Teacher displays } \\
\text { generally accurate } \\
\text { knowledge of } \\
\text { developmental } \\
\text { characteristics of age } \\
\text { group. }\end{array}$ & $\begin{array}{l}\text { Teacher displays } \\
\text { understanding of typical } \\
\text { developmental } \\
\text { characteristics of age } \\
\text { group and expects } \\
\text { patterns and problems. }\end{array}$ & $\begin{array}{l}\text { Teacher displays knowledge of } \\
\text { typical developmental } \\
\text { characteristics of age group, } \\
\text { exceptions to the patterns, and } \\
\text { spiritual needs of the age } \\
\text { group. }\end{array}$ \\
\hline $\begin{array}{l}\text { Varied } \\
\text { Approaches } 10 \\
\text { Learning }\end{array}$ & $\begin{array}{l}\text { Teacher is unfamiliar } \\
\text { with different } \\
\text { approaches to learning, } \\
\text { such as learning styles, } \\
\text { modalities, learning } \\
\text { differences, and } \\
\text { different "intelligences." }\end{array}$ & $\begin{array}{l}\text { Teacher displays } \\
\text { general understanding } \\
\text { of the different } \\
\text { approaches to learning } \\
\text { that student exhibit. } \\
\text { Teacher is aware of } \\
\text { learning differences in } \\
\text { the students population } \\
\text { and in his/her classes. }\end{array}$ & $\begin{array}{l}\text { Teacher displays solid } \\
\text { understanding of the } \\
\text { different approaches to } \\
\text { learning that different } \\
\text { students exhibit. } \\
\text { He/She is aware of } \\
\text { student learning } \\
\text { differences among } \\
\text { his/her students and } \\
\text { how to effect learning } \\
\text { for students with these } \\
\text { variations. }\end{array}$ & $\begin{array}{l}\text { Teacher uses, where } \\
\text { appropriate, knowledge of } \\
\text { students' varied approaches to } \\
\text { learning in instructional } \\
\text { planning. Teacher knows } \\
\text { which students require varied } \\
\text { instruction and has a repertoire } \\
\text { of skills he/she may draw from } \\
\text { in planning how to teach these } \\
\text { students effectively. }\end{array}$ \\
\hline
\end{tabular}

Text on these pages adapted from ETS Pathwise materials 


\begin{tabular}{|c|c|c|c|c|}
\hline \multicolumn{5}{|c|}{ Component 1c: Selecting Instructional Goals } \\
\hline \multirow[b]{2}{*}{ Element } & \multicolumn{4}{|c|}{ Level of Performance } \\
\hline & Unsatisfactory & Basic & Proficient & Distinguished \\
\hline $\begin{array}{l}\text { Setling } \\
\text { Valuable } \\
\text { Goals }\end{array}$ & $\begin{array}{l}\text { Goals are absent from } \\
\text { planning or are not } \\
\text { valuable and represent } \\
\text { low expectations or } \\
\text { little conceptual } \\
\text { understanding for } \\
\text { students. Goals rarely } \\
\text { reflect important } \\
\text { learning. }\end{array}$ & $\begin{array}{l}\text { Goals are usually } \\
\text { present in planning. } \\
\text { Goals are moderately } \\
\text { valuable in either their } \\
\text { expectations for } \\
\text { conceptual } \\
\text { understanding and } \\
\text { important learning. }\end{array}$ & $\begin{array}{l}\text { Goals are always } \\
\text { present in planning } \\
\text { documents and are } \\
\text { valuable in their level of } \\
\text { expectations, conceptual } \\
\text { understanding and } \\
\text { important learning. }\end{array}$ & $\begin{array}{l}\text { Goals are always present and } \\
\text { are obviously valuable in } \\
\text { relation to their conceptual } \\
\text { understanding, level of } \\
\text { expectation, and focus on } \\
\text { important learning. Teacher } \\
\text { can also clearly articulate how } \\
\text { goals establish high } \\
\text { expectations and relate to } \\
\text { curriculum. }\end{array}$ \\
\hline $\begin{array}{l}\text { Clarity of } \\
\text { Goals }\end{array}$ & $\begin{array}{l}\text { Goals are often unclear } \\
\text { or they are stated as } \\
\text { student activities. Goals } \\
\text { lack viable methods of } \\
\text { assessment }\end{array}$ & $\begin{array}{l}\text { Goals are moderately } \\
\text { clear or include a } \\
\text { combination of goals } \\
\text { and activities. Some } \\
\text { goals do not permit } \\
\text { viable methods of } \\
\text { assessment. }\end{array}$ & $\begin{array}{l}\text { Most goals are clear but } \\
\text { may include a few } \\
\text { activities. Most permit } \\
\text { viable methods of } \\
\text { assessment. }\end{array}$ & $\begin{array}{l}\text { All the goals are clear; written } \\
\text { in the form of student learning, } \\
\text { and permit viable methods of } \\
\text { assessment. }\end{array}$ \\
\hline
\end{tabular}

\begin{tabular}{|l|l|l|l|l|}
\hline Component & 1d: Demonstrating Knowledge of Resources & \multicolumn{2}{|c|}{ (back to framework) } \\
\hline \multirow{2}{*}{$\begin{array}{l}\text { Element } \\
\text { Resources for } \\
\text { Teaching }\end{array}$} & $\begin{array}{l}\text { Unsatisfactory } \\
\text { Tesources available } \\
\text { through the school or } \\
\text { the community. }\end{array}$ & $\begin{array}{l}\text { Basic } \\
\text { awareness of resources } \\
\text { available through the } \\
\text { school and the } \\
\text { community. }\end{array}$ & $\begin{array}{l}\text { Level of Performance } \\
\text { of many resources } \\
\text { available through the } \\
\text { school and the } \\
\text { community. }\end{array}$ & $\begin{array}{l}\text { In addition to being aware of } \\
\text { school and community } \\
\text { resources, the teacher seeks to } \\
\text { strengthen resources and to } \\
\text { make others aware of } \\
\text { resources. }\end{array}$ \\
\hline $\begin{array}{l}\text { Resources for } \\
\text { students }\end{array}$ & $\begin{array}{l}\text { Teacher is unaware or } \\
\text { disregards resources } \\
\text { available to assist } \\
\text { students who need them. }\end{array}$ & $\begin{array}{l}\text { Teacher displays limited } \\
\text { awareness of or respect } \\
\text { for resources available } \\
\text { through the school or } \\
\text { the community to help } \\
\text { students who need them. }\end{array}$ & $\begin{array}{l}\text { Teacher is fully aware } \\
\text { of all resources } \\
\text { available through the } \\
\text { school or the } \\
\text { community and knows } \\
\text { how to gain access for } \\
\text { students. }\end{array}$ & $\begin{array}{l}\text { In addition to being aware of } \\
\text { school and community } \\
\text { resources for students who } \\
\text { need them, the teacher seeks to } \\
\text { strengthen the school's } \\
\text { resources. }\end{array}$ \\
\hline
\end{tabular}

Text on these pages adapted from ETS Pathwise materials 


\begin{tabular}{|c|c|c|c|c|}
\hline \multicolumn{5}{|c|}{ Component 1e: Designing Coherent Instruction } \\
\hline \multirow[b]{2}{*}{ Element } & \multicolumn{4}{|c|}{ Level of Performance } \\
\hline & Unsatisfactory & Basic & Proficient & Distinguished \\
\hline $\begin{array}{l}\text { Learning } \\
\text { Activities }\end{array}$ & $\begin{array}{l}\text { Learning activities are } \\
\text { not suitable to students } \\
\text { or instructional goals. } \\
\text { They do not follow an } \\
\text { organized progression. }\end{array}$ & $\begin{array}{l}\text { Only some of the } \\
\text { learning activities are } \\
\text { suitable to students or } \\
\text { instructional goals. } \\
\text { Progression of activities } \\
\text { in the unit is uneven. }\end{array}$ & $\begin{array}{l}\text { Most of the learning } \\
\text { activities are suitable to } \\
\text { students and } \\
\text { instructional goals. } \\
\text { Progression of activities } \\
\text { is fairly even. }\end{array}$ & $\begin{array}{l}\text { Learning activities are highly } \\
\text { relevant to students and } \\
\text { instructional goals. They } \\
\text { progress coherently, producing } \\
\text { unified lessons and units. }\end{array}$ \\
\hline $\begin{array}{l}\text { Instructional } \\
\text { Materials and } \\
\text { Resources }\end{array}$ & $\begin{array}{l}\text { Materials and resources } \\
\text { rarely support the } \\
\text { instructional goals or to } \\
\text { engage students in } \\
\text { meaningful learning. }\end{array}$ & $\begin{array}{l}\text { Some of the materials } \\
\text { and resources support } \\
\text { the instructional goals, } \\
\text { and some engage } \\
\text { students in meaningful } \\
\text { learning. }\end{array}$ & $\begin{array}{l}\text { All materials and } \\
\text { resources support the } \\
\text { instructional goals and } \\
\text { most engage students in } \\
\text { meaningful learning. }\end{array}$ & $\begin{array}{l}\text { All materials and resources } \\
\text { support the instructional goals } \\
\text { and most engage students in } \\
\text { meaningful learning. There is } \\
\text { evidence of students' } \\
\text { participation in adapting or } \\
\text { selecting materials. }\end{array}$ \\
\hline $\begin{array}{l}\text { Instructional } \\
\text { Groups and } \\
\text { Cooperative } \\
\text { Learning }\end{array}$ & $\begin{array}{l}\text { Instructional groups do } \\
\text { not seem to support the } \\
\text { instructional goals. } \\
\text { Instructional groups and } \\
\text { cooperative learning are } \\
\text { rarely or never used. }\end{array}$ & $\begin{array}{l}\text { Instructional groups and } \\
\text { cooperative learning are } \\
\text { sometimes suitable to } \\
\text { the instructional goals } \\
\text { and are used } \\
\text { occasionally. }\end{array}$ & $\begin{array}{l}\text { Instructional groups and } \\
\text { cooperative learning are } \\
\text { used frequently and } \\
\text { effectively. There is } \\
\text { variety in cooperative } \\
\text { learning as appropriate } \\
\text { for instructional goals. }\end{array}$ & $\begin{array}{l}\text { Instructional groups and } \\
\text { cooperative learning are used } \\
\text { frequently and effectively. } \\
\text { There is variety in cooperative } \\
\text { learning as appropriate for } \\
\text { instructional goals. Students } \\
\text { appear to have choice in } \\
\text { selecting different cooperative } \\
\text { patterns to reach instructional } \\
\text { goals. }\end{array}$ \\
\hline $\begin{array}{l}\text { Lesson and } \\
\text { Unit Structure }\end{array}$ & $\begin{array}{l}\text { The lesson or units } \\
\text { rarely have defined } \\
\text { structure, or the } \\
\text { structure is chaotic. } \\
\text { Time allocations and } \\
\text { pacing are usually } \\
\text { unrealistic }\end{array}$ & $\begin{array}{l}\text { The lesson or unit has a } \\
\text { basic recognizable } \\
\text { structure. Most pacing } \\
\text { and time allocations are } \\
\text { reasonable. }\end{array}$ & $\begin{array}{l}\text { The lessons or units } \\
\text { have clearly defined } \\
\text { structure that activities } \\
\text { are organized around. } \\
\text { Time allocation and } \\
\text { pacing are nearly } \\
\text { always reasonable. }\end{array}$ & $\begin{array}{l}\text { Lesson and unit structure are } \\
\text { clear and allow for different } \\
\text { pathways according to } \\
\text { individual student needs. Time } \\
\text { allocation and pacing are } \\
\text { always reasonable. }\end{array}$ \\
\hline
\end{tabular}

\begin{tabular}{|c|c|c|c|c|}
\hline \multicolumn{5}{|c|}{ Component 1f: Assessing Student Learning } \\
\hline \multirow[b]{2}{*}{ Element } & \multicolumn{4}{|c|}{ Level of Performance } \\
\hline & Unsatisfactory & Basic & Proficient & Distinguished \\
\hline $\begin{array}{l}\text { Congruence } \\
\text { with } \\
\text { Instructional } \\
\text { Goals }\end{array}$ & $\begin{array}{l}\text { Tests and alternative } \\
\text { approaches are not used } \\
\text { consistently to measure } \\
\text { achievement of } \\
\text { objectives or the } \\
\text { instruments and } \\
\text { assignments fail to } \\
\text { measure objectives. }\end{array}$ & $\begin{array}{l}\text { Some of the } \\
\text { instructional goals are } \\
\text { assessed through test } \\
\text { instruments and } \\
\text { assignments, but some } \\
\text { are not. }\end{array}$ & $\begin{array}{l}\text { All the instructional } \\
\text { goals are nominally } \\
\text { assessed through } \\
\text { instruments, but the } \\
\text { approaches used are } \\
\text { more suitable to some } \\
\text { objectives than to } \\
\text { others. }\end{array}$ & $\begin{array}{l}\text { Assessments and assignments } \\
\text { are completely congruent to } \\
\text { instructional goals and } \\
\text { objectives in content and } \\
\text { process. }\end{array}$ \\
\hline $\begin{array}{l}\text { Communica- } \\
\text { tion of Criteria }\end{array}$ & $\begin{array}{l}\text { Criteria for measurement } \\
\text { of learning are poorly } \\
\text { developed or are they not } \\
\text { consistently commu- } \\
\text { nicated to students. }\end{array}$ & $\begin{array}{l}\text { Assessment criteria are } \\
\text { developed, but criteria } \\
\text { are not clear to } \\
\text { students. }\end{array}$ & $\begin{array}{l}\text { Assessment criteria and } \\
\text { standards are clear and } \\
\text { have been clearly } \\
\text { communicated to } \\
\text { students. }\end{array}$ & $\begin{array}{l}\text { Assessment criteria and } \\
\text { standards are clear and have } \\
\text { been communicated to } \\
\text { students. There is evidence } \\
\text { that students have contributed } \\
\text { and have "bought in" to the } \\
\text { standards and criteria. }\end{array}$ \\
\hline
\end{tabular}

Text on these pages adapted from ETS Pathwise materials 


\section{Domain II: Classroom Environment}

\begin{tabular}{|c|c|c|c|c|}
\hline \multicolumn{5}{|c|}{ Component 2a: Creating and Environment of Respect and Rapport } \\
\hline \multirow[b]{2}{*}{ Element } & \multicolumn{4}{|c|}{ Level of Performance } \\
\hline & Unsatisfactory & Basic & Proficient & Distinguished \\
\hline $\begin{array}{l}\text { Teacher } \\
\text { interaction } \\
\text { with } \\
\text { students }\end{array}$ & $\begin{array}{l}\text { Teacher interacts with at } \\
\text { least some students in } \\
\text { ways that are negative, } \\
\text { demeaning, sarcastic, or } \\
\text { inappropriate to the age } \\
\text { or culture of the } \\
\text { students. Students } \\
\text { exhibit disrespect for } \\
\text { the teacher }\end{array}$ & $\begin{array}{l}\text { Teacher-student } \\
\text { interactions are } \\
\text { generally appropriate } \\
\text { but may reflect } \\
\text { occasional negativity, } \\
\text { favoritism, or } \\
\text { moodiness. Some } \\
\text { students exhibit respect } \\
\text { for the teacher. }\end{array}$ & $\begin{array}{l}\text { Teacher-student } \\
\text { interactions are friendly } \\
\text { and demonstrate general } \\
\text { warmth, caring, and } \\
\text { respect. Such } \\
\text { interactions are } \\
\text { appropriate to } \\
\text { developmental and } \\
\text { cultural norms. Most } \\
\text { students exhibit respect } \\
\text { for the teacher. }\end{array}$ & $\begin{array}{l}\text { Teacher demonstrates } \\
\text { consistent and genuine caring } \\
\text { and respect for individual } \\
\text { students. Students respect the } \\
\text { teacher as an individual beyond } \\
\text { that of the role. }\end{array}$ \\
\hline $\begin{array}{l}\text { Student } \\
\text { Interaction }\end{array}$ & $\begin{array}{l}\text { Student interactions in } \\
\text { the teacher's presence } \\
\text { are characterized by } \\
\text { conflict, sarcasm, or } \\
\text { put-downs. }\end{array}$ & $\begin{array}{l}\text { Students do not } \\
\text { demonstrate negative } \\
\text { behavior toward one } \\
\text { another. }\end{array}$ & $\begin{array}{l}\text { Student interactions are } \\
\text { generally polite and } \\
\text { respectful. }\end{array}$ & $\begin{array}{l}\text { Students demonstrate genuine } \\
\text { caring or one another as } \\
\text { individuals and as students. }\end{array}$ \\
\hline
\end{tabular}

\begin{tabular}{|c|c|c|c|c|}
\hline \multicolumn{5}{|c|}{ Component 2b: Establishing a Culture for Learning } \\
\hline \multirow[b]{2}{*}{ Element } & \multicolumn{4}{|c|}{ Level of Performance } \\
\hline & Unsatisfactory & Basic & Proficient & Distinguished \\
\hline $\begin{array}{l}\text { Inportance of } \\
\text { Content }\end{array}$ & $\begin{array}{l}\text { Teacher or students } \\
\text { convey a negative } \\
\text { attitude toward the } \\
\text { content, suggesting the } \\
\text { content is not important } \\
\text { or is mandated by } \\
\text { others. }\end{array}$ & $\begin{array}{l}\text { Teacher communicates } \\
\text { some importance of } \\
\text { content and students } \\
\text { superficially buy-in. }\end{array}$ & $\begin{array}{l}\text { Teacher conveys } \\
\text { genuine enthusiasm for } \\
\text { the subject, and } \\
\text { students demonstrate } \\
\text { consistent commitment } \\
\text { to its value. }\end{array}$ & $\begin{array}{l}\text { Teacher conveys genuine } \\
\text { enthusiasm for the subject. } \\
\text { Students demonstrate through } \\
\text { their active participation, } \\
\text { curiosity, and attention to detail } \\
\text { that they value the content's } \\
\text { importance. }\end{array}$ \\
\hline $\begin{array}{l}\text { Student } \\
\text { commitment } \\
\text { to excellence }\end{array}$ & $\begin{array}{l}\text { Many students } \\
\text { demonstrate little to no } \\
\text { commitment to } \\
\text { excellence in their class } \\
\text { work. They only desire } \\
\text { to get tasks done rather } \\
\text { than to do high-quality } \\
\text { work. }\end{array}$ & $\begin{array}{l}\text { Most students accept the } \\
\text { responsibility to do good } \\
\text { work, but some invest } \\
\text { little of their energy in } \\
\text { the quality of the work. } \\
\text { For some there is } \\
\text { evidence that the teacher } \\
\text { has strengthened pride in } \\
\text { work. }\end{array}$ & $\begin{array}{l}\text { Most students accept } \\
\text { teacher insistence that } \\
\text { work must be of high } \\
\text { quality and many } \\
\text { demonstrate } \\
\text { commitment to } \\
\text { personal excellence. }\end{array}$ & $\begin{array}{l}\text { Students take obvious pride in } \\
\text { their work and initiate } \\
\text { improvement in it. There is } \\
\text { evidence that teacher's } \\
\text { commitment to excellence is } \\
\text { contagious in nearly all of the } \\
\text { students. }\end{array}$ \\
\hline $\begin{array}{l}\text { Expectations } \\
\text { for leaming } \\
\text { and } \\
\text { Achievenent }\end{array}$ & $\begin{array}{l}\text { Instructional goals and } \\
\text { activities, interactions, } \\
\text { and the classroom } \\
\text { environment convey } \\
\text { only modest } \\
\text { expectations for student } \\
\text { achievement }\end{array}$ & $\begin{array}{l}\text { Instructional goals and } \\
\text { activities, interactions, } \\
\text { and the classroom } \\
\text { environment convey } \\
\text { moderate expectations } \\
\text { for student achievement }\end{array}$ & $\begin{array}{l}\text { Instructional goals and } \\
\text { activities, interactions, } \\
\text { and the classroom } \\
\text { environment convey } \\
\text { high expectations for } \\
\text { student achievement }\end{array}$ & $\begin{array}{l}\text { Students assist in establishing } \\
\text { and maintaining very high } \\
\text { expectations for everyone. } \\
\text { Instructional goals and } \\
\text { activities, interactions, and the } \\
\text { classroom environment convey } \\
\text { very high-yet reasonable-- } \\
\text { expectations. }\end{array}$ \\
\hline
\end{tabular}

Text on these pages adapted from ETS Pathwise materials 


\begin{tabular}{|c|c|c|c|c|}
\hline \multicolumn{5}{|c|}{ Component 2c: Managing Classroom Procedures } \\
\hline \multirow[b]{2}{*}{ Element } & \multicolumn{4}{|c|}{ Level of Performance } \\
\hline & Unsatisfactory & Basic & Proficient & Distinguished \\
\hline $\begin{array}{l}\text { Management } \\
\text { of } \\
\text { Instructional } \\
\text { Groups }\end{array}$ & $\begin{array}{l}\text { Students not directly } \\
\text { working with the } \\
\text { teacher are not } \\
\text { productively engage in } \\
\text { learning. }\end{array}$ & $\begin{array}{l}\text { Tasks for group/seat } \\
\text { work are partially } \\
\text { organized. There is } \\
\text { some off-task behavior } \\
\text { when teacher is working } \\
\text { with one group. }\end{array}$ & $\begin{array}{l}\text { Tasks for group/seat } \\
\text { work are organized and } \\
\text { groups are managed so } \\
\text { most students are } \\
\text { engaged most of the } \\
\text { time. }\end{array}$ & $\begin{array}{l}\text { Groups working independently } \\
\text { are productively engaged at all } \\
\text { times, with students assuming } \\
\text { the responsibility of } \\
\text { productivity. }\end{array}$ \\
\hline $\begin{array}{l}\text { Management } \\
\text { of Transitions }\end{array}$ & $\begin{array}{l}\text { Much time is lost before } \\
\text { and after class changes } \\
\text { and/or during in-class } \\
\text { transitions. }\end{array}$ & $\begin{array}{l}\text { Some instructional time } \\
\text { is lost before and after } \\
\text { class changes and/or } \\
\text { during in-class } \\
\text { transitions. }\end{array}$ & $\begin{array}{l}\text { Transitions are smooth } \\
\text { with little instructional } \\
\text { time lost before and } \\
\text { after class changes } \\
\text { and/or during in-class } \\
\text { transitions. }\end{array}$ & $\begin{array}{l}\text { Transitions are seamless, with } \\
\text { students assuring responsibility } \\
\text { for efficient operation. Very } \\
\text { rarely is instructional time lost } \\
\text { before and after class changes } \\
\text { and/or during in-class } \\
\text { transitions. }\end{array}$ \\
\hline $\begin{array}{l}\text { Management } \\
\text { of Materials } \\
\text { and Supplies }\end{array}$ & $\begin{array}{l}\text { Materials are handled } \\
\text { inefficiently resulting in } \\
\text { loss of instructional } \\
\text { time and/or large waste } \\
\text { of materials. }\end{array}$ & $\begin{array}{l}\text { Routines for handling } \\
\text { materials and supplies } \\
\text { function moderately } \\
\text { well. There is little } \\
\text { waste of time and/or } \\
\text { resources. }\end{array}$ & $\begin{array}{l}\text { Routines for handling } \\
\text { materials and supplies } \\
\text { occur smoothly, with no } \\
\text { loss of instructional } \\
\text { time and/or no waste of } \\
\text { resources. }\end{array}$ & $\begin{array}{l}\text { Routines for handling materials } \\
\text { and supplies are seamless, with } \\
\text { students assisting with } \\
\text { operations. There is no } \\
\text { apparent waste of time or } \\
\text { resources. }\end{array}$ \\
\hline $\begin{array}{l}\text { Performance } \\
\text { of Non- } \\
\text { Instructional } \\
\text { Duties }\end{array}$ & $\begin{array}{l}\text { Considerable } \\
\text { instructional time is lost } \\
\text { to perform non- } \\
\text { instructional duties such } \\
\text { as completing } \\
\text { attendance, granting } \\
\text { passes, or processing } \\
\text { paperwork. }\end{array}$ & $\begin{array}{l}\text { Systems for performing } \\
\text { non-instructional duties } \\
\text { are fairly efficient, } \\
\text { resulting in some loss of } \\
\text { instructional time. }\end{array}$ & $\begin{array}{l}\text { Efficient systems for } \\
\text { performing non- } \\
\text { instructional duties are } \\
\text { in place, resulting in } \\
\text { minimal loss of } \\
\text { instructional time. }\end{array}$ & $\begin{array}{l}\text { Systems for performing non- } \\
\text { instructional duties are well } \\
\text { established, with students } \\
\text { assuming considerable } \\
\text { responsibility for efficient } \\
\text { operations. }\end{array}$ \\
\hline
\end{tabular}

\begin{tabular}{|c|c|c|c|c|}
\hline \multicolumn{4}{|c|}{ Component 2d: Managing Student Behavior } & (back to framework) \\
\hline \multirow[b]{2}{*}{ Element } & \multicolumn{4}{|c|}{ Level of Performance } \\
\hline & Unsatisfactory & Basic & Proficient & Distinguished \\
\hline Fxpectations & $\begin{array}{l}\text { Very few standards of } \\
\text { conduct appear to have } \\
\text { been established, or } \\
\text { students are confused } \\
\text { about what the } \\
\text { standards are. }\end{array}$ & $\begin{array}{l}\text { Standards of conduct } \\
\text { appear to have been } \\
\text { established for most } \\
\text { situations, and most } \\
\text { students seem to } \\
\text { understand them. }\end{array}$ & $\begin{array}{l}\text { Standards of conduct } \\
\text { are clear to all students. }\end{array}$ & $\begin{array}{l}\text { Standards of conduct are clear } \\
\text { to all students and appear to } \\
\text { have been developed with } \\
\text { student participation. }\end{array}$ \\
\hline $\begin{array}{l}\text { Monitoring } \\
\text { Student } \\
\text { Behavior }\end{array}$ & $\begin{array}{l}\text { Student behavior is } \\
\text { rarely monitored, and } \\
\text { teacher is usually } \\
\text { unaware of what some } \\
\text { students are doing. } \\
\text { Teacher has } \\
\text { occasionally left some } \\
\text { or all students } \\
\text { unsupervised or has } \\
\text { misses assigned } \\
\text { supervisory duties. }\end{array}$ & $\begin{array}{l}\text { Teacher is generally } \\
\text { aware of student } \\
\text { behavior. Teacher } \\
\text { sometimes misses the } \\
\text { inappropriate activities } \\
\text { of students in the } \\
\text { classroom. Supervision } \\
\text { is sometimes contributed } \\
\text { in hallways, at lunch, } \\
\text { and during activities as } \\
\text { assigned. }\end{array}$ & $\begin{array}{l}\text { Teacher is alert to } \\
\text { student behavior at all } \\
\text { times and rarely misses } \\
\text { inappropriate behavior. } \\
\text { Teacher is often seen } \\
\text { monitoring hallways, } \\
\text { lunchroom and in other } \\
\text { areas besides his or her } \\
\text { own classroom. }\end{array}$ & $\begin{array}{l}\text { Monitoring by teacher is } \\
\text { complete, subtle and } \\
\text { preventive. Teacher frequently } \\
\text { and consistently takes initiative } \\
\text { in supervising students in } \\
\text { hallways, lunch, and during } \\
\text { activities beyond assigned } \\
\text { supervisory duty. }\end{array}$ \\
\hline $\begin{array}{l}\text { Response to } \\
\text { Student } \\
\text { Misbehavior }\end{array}$ & $\begin{array}{l}\text { Teacher does not } \\
\text { respond to misbehavior, } \\
\text { or the response is } \\
\text { inconsistent, overly } \\
\text { repressive, angry, or } \\
\text { does not respect the } \\
\text { students' dignity. }\end{array}$ & $\begin{array}{l}\text { Teacher attempts to } \\
\text { respond to student } \\
\text { misbehavior but with } \\
\text { uneven results, or no } \\
\text { serious misbehavior } \\
\text { occurs. }\end{array}$ & $\begin{array}{l}\text { Teacher response to } \\
\text { misbehavior is } \\
\text { appropriate and } \\
\text { successful and respects } \\
\text { the student's dignity, or } \\
\text { student behavior is } \\
\text { generally appropriate. }\end{array}$ & $\begin{array}{l}\text { Teacher response to } \\
\text { misbehavior is highly effective } \\
\text { and sensitive to students' } \\
\text { individual needs, or student } \\
\text { behavior is entirely appropriate. }\end{array}$ \\
\hline
\end{tabular}




\begin{tabular}{|c|c|c|c|c|}
\hline \multicolumn{4}{|c|}{ Component 2e: Organizing Physical Space } & \multirow[t]{2}{*}{ (back to framework) } \\
\hline \multirow[b]{2}{*}{ Element } & \multicolumn{3}{|c|}{ Level of Performance } & \\
\hline & Unsatisfactory & Basic & Proficient & Distinguished \\
\hline $\begin{array}{l}\text { Classroom } \\
\text { effectiveness } \\
\text { and Safety }\end{array}$ & $\begin{array}{l}\text { The classroom in unsafe or } \\
\text { not suitable of learning. } \\
\text { Example: Fire exits are } \\
\text { blocked or maintenance is } \\
\text { not contacted for necessary } \\
\text { repairs. }\end{array}$ & $\begin{array}{l}\text { The classroom in safe } \\
\text { and is generally } \\
\text { sensibly arranged for } \\
\text { effectiveness. }\end{array}$ & $\begin{array}{l}\text { The classroom is a safe } \\
\text { resource for learning } \\
\text { activities. The class } \\
\text { room is usually neatly } \\
\text { arranged. }\end{array}$ & $\begin{array}{l}\text { The classroom is safe, and is } \\
\text { always neatly arranged with } \\
\text { students maintaining neatness. }\end{array}$ \\
\hline $\begin{array}{l}\text { ()rganization } \\
\text { and neatness. }\end{array}$ & $\begin{array}{l}\text { Classroom is frequently } \\
\text { disorganized and/ or messy } \\
\text { with piles of paper, trash, } \\
\text { and other materials } \\
\text { creating clutter on the } \\
\text { floor, furniture and/or } \\
\text { teacher's desk. } \\
\text { Disorganization and } \\
\text { messiness diminish } \\
\text { teacher's effectiveness. }\end{array}$ & $\begin{array}{l}\text { Classroom is } \\
\text { sometimes neat and } \\
\text { organized and } \\
\text { appears messy at } \\
\text { other times. } \\
\text { Disorganization } \\
\text { rarely diminishes } \\
\text { teacher's } \\
\text { effectiveness. }\end{array}$ & $\begin{array}{l}\text { Classroom is usually } \\
\text { neat and organized and } \\
\text { only rarely messy. } \\
\text { Organization and } \\
\text { neatness contribute to } \\
\text { teacher's effectiveness. }\end{array}$ & $\begin{array}{l}\text { Classroom is noticeably } \\
\text { organized and never messy. } \\
\text { Students contribute to } \\
\text { maintenance of neatness. } \\
\text { Teacher reaches out to give } \\
\text { others hints on organization } \\
\text { and neatness. }\end{array}$ \\
\hline
\end{tabular}

\begin{tabular}{|c|c|c|c|c|}
\hline \multicolumn{4}{|c|}{ Component 2f: Ministry to Students } & \multirow[t]{2}{*}{ (back to framework) } \\
\hline \multirow[b]{2}{*}{ Element } & \multicolumn{3}{|c|}{ Level of Performance } & \\
\hline & Unsatisfactory & Basic & Proficient & Distinguished \\
\hline $\begin{array}{l}\text { Supporting } \\
\text { discipleship }\end{array}$ & $\begin{array}{l}\text { Teacher never discusses } \\
\text { students' Christian } \\
\text { growth. Teacher has no } \\
\text { personal spiritual } \\
\text { ministry in school. }\end{array}$ & $\begin{array}{l}\text { Teacher sometimes uses } \\
\text { advisory time and } \\
\text { personal interaction with } \\
\text { students to encourage } \\
\text { students in their spiritual } \\
\text { walk. }\end{array}$ & $\begin{array}{l}\text { In addition to chapel } \\
\text { and advisory groups, } \\
\text { teacher develops some } \\
\text { relationships with } \\
\text { students that facilitate } \\
\text { their growth in } \\
\text { Christian discipleship. }\end{array}$ & $\begin{array}{l}\text { In addition to chapel and } \\
\text { advisory group, teacher } \\
\text { actively and consistently } \\
\text { develops many relationships } \\
\text { with students that encourage } \\
\text { the students to grow spiritually } \\
\text { and encourages other teachers } \\
\text { to do the same. }\end{array}$ \\
\hline $\begin{array}{l}\text { Training } \\
\text { leaders }\end{array}$ & $\begin{array}{l}\text { Teacher shows little or } \\
\text { no support of the } \\
\text { school's mission to train } \\
\text { Christian leaders. }\end{array}$ & $\begin{array}{l}\text { Teacher generally } \\
\text { supports the school's } \\
\text { effort to train leaders in } \\
\text { the student body. }\end{array}$ & $\begin{array}{l}\text { Teacher frequently } \\
\text { encourages students to } \\
\text { become leaders for } \\
\text { Christ through } \\
\text { coaching, mentoring, } \\
\text { leadership training, } \\
\text { and/or involvement } \\
\text { with student } \\
\text { organizations. }\end{array}$ & $\begin{array}{l}\text { Teacher takes initiative to } \\
\text { foster leadership in students } \\
\text { and other teachers through } \\
\text { coaching, mentoring, creation } \\
\text { of formal programs, and/or } \\
\text { extensive involvement in } \\
\text { student organizations. }\end{array}$ \\
\hline $\begin{array}{l}\text { Giving the } \\
\text { gospel }\end{array}$ & $\begin{array}{l}\text { Teacher makes no } \\
\text { attempt or has no } \\
\text { interest in giving the } \\
\text { gospel to students. }\end{array}$ & $\begin{array}{l}\text { In classrooms and in } \\
\text { personal interactions, the } \\
\text { teacher gives the gospel } \\
\text { occasionally to students. }\end{array}$ & $\begin{array}{l}\text { Teacher frequently } \\
\text { relates the gospel in } \\
\text { personal interactions } \\
\text { with students, in the } \\
\text { classroom, and in } \\
\text { outreach programs. }\end{array}$ & $\begin{array}{l}\text { Teacher is a very consistent } \\
\text { witness for Christ in the } \\
\text { classroom, and in interactions } \\
\text { with students. Teacher targets } \\
\text { unsaved students and tries to } \\
\text { reach them for Christ. Teacher } \\
\text { encourages other students and } \\
\text { faculty to witness. }\end{array}$ \\
\hline
\end{tabular}

Text on these pages adapted from ETS Pathwise materials 


\section{Domain III: Instruction}

\begin{tabular}{|c|c|c|c|c|}
\hline \multicolumn{5}{|c|}{ Component 3a: Communicating Clearly and Accurately } \\
\hline \multirow[b]{2}{*}{ Element } & \multicolumn{4}{|c|}{ Level of Performance } \\
\hline & Unsatisfactory & Basic & Proficient & Distinguished \\
\hline $\begin{array}{l}\text { Directions and } \\
\text { Procedures }\end{array}$ & $\begin{array}{l}\text { Teacher's spoken and } \\
\text { written directions and } \\
\text { procedures are often } \\
\text { confusing to students. }\end{array}$ & $\begin{array}{l}\text { Teacher's spoken and } \\
\text { written directions and } \\
\text { procedures are clarified } \\
\text { after initial student } \\
\text { confusion. }\end{array}$ & $\begin{array}{l}\text { Teacher's spoken and } \\
\text { written directions and } \\
\text { procedures are clear to } \\
\text { students and contain an } \\
\text { appropriate level of } \\
\text { detail. }\end{array}$ & $\begin{array}{l}\text { Teacher's spoken and written } \\
\text { directions and procedures are } \\
\text { clear to students. Teacher } \\
\text { anticipates possible student } \\
\text { misunderstanding. }\end{array}$ \\
\hline $\begin{array}{l}\text { Oral and } \\
\text { Written } \\
\text { Language. }\end{array}$ & $\begin{array}{l}\text { Teacher's spoken } \\
\text { language in inaudible, } \\
\text { or written language in } \\
\text { illegible. Spoken or } \\
\text { written language } \\
\text { contains grammar and } \\
\text { spelling errors. } \\
\text { Vocabulary may be } \\
\text { incorrect, full of slang } \\
\text { terms, or otherwise } \\
\text { inappropriate at times. }\end{array}$ & $\begin{array}{l}\text { Teacher's spoken } \\
\text { language is audible, and } \\
\text { written language is } \\
\text { legible. Both are } \\
\text { usually effective and } \\
\text { correct. Teacher uses } \\
\text { little slang and never } \\
\text { uses inappropriate } \\
\text { vocabulary. }\end{array}$ & $\begin{array}{l}\text { Teacher's spoken and } \\
\text { written language is } \\
\text { clear and correct. } \\
\text { Vocabulary is } \\
\text { professional but } \\
\text { appropriate to students' } \\
\text { age. Teacher never } \\
\text { uses inappropriate } \\
\text { vocabulary. }\end{array}$ & $\begin{array}{l}\text { Teacher's spoken and written } \\
\text { language is expressive, clear, } \\
\text { and correct. Spoken language } \\
\text { commands the audience and } \\
\text { written language is inspiring. } \\
\text { Well-chosen vocabulary } \\
\text { enriches lessons and } \\
\text { communication. }\end{array}$ \\
\hline
\end{tabular}

\begin{tabular}{|l|l|l|l|l|}
\hline Component 3b: Using Questioning and Discussion Techniques & \multicolumn{2}{|c|}{ Level of Performance } \\
\hline \multirow{4}{*}{ Element } & Unsatisfactory & Basic & Proficient & Distinguished \\
\cline { 2 - 5 } & $\begin{array}{l}\text { Teacher does not ask } \\
\text { questions or the } \\
\text { questions are virtually } \\
\text { all of poor quality. }\end{array}$ & $\begin{array}{l}\text { Teacher's questions } \\
\text { vary in quality. Some } \\
\text { questions invite a } \\
\text { response. }\end{array}$ & $\begin{array}{l}\text { Most of the teacher's } \\
\text { questions are of high } \\
\text { quality. Adequate time } \\
\text { is available for students } \\
\text { to respond. Students } \\
\text { ask a few questions. }\end{array}$ & $\begin{array}{l}\text { Teacher's questions are of } \\
\text { uniformly high quality, with } \\
\text { adequate time for students to } \\
\text { respond. Students direct many } \\
\text { questions to the teacher. }\end{array}$ \\
\hline $\begin{array}{l}\text { Discussion } \\
\text { Techniques }\end{array}$ & $\begin{array}{l}\text { There is no discussion } \\
\text { or interaction between } \\
\text { teacher and students is } \\
\text { predominantly in } \\
\text { recitation style, with } \\
\text { teacher mediating all } \\
\text { questions and answers. }\end{array}$ & $\begin{array}{l}\text { Teacher makes some } \\
\text { attempt to engage } \\
\text { students in a true } \\
\text { discussion, with uneven } \\
\text { results. Some } \\
\text { discussions contribute } \\
\text { to learning. }\end{array}$ & $\begin{array}{l}\text { Classroom interaction } \\
\text { represents true } \\
\text { discussion, with teacher } \\
\text { stepping, when } \\
\text { appropriate, to the side. } \\
\text { Most discussions } \\
\text { contribute to learning. }\end{array}$ & $\begin{array}{l}\text { Students assume considerable } \\
\text { responsibility for the success of } \\
\text { the discussion, initiating topics } \\
\text { and making unsolicited } \\
\text { contributions. Nearly all } \\
\text { discussions contribute to } \\
\text { learning. }\end{array}$ \\
\hline $\begin{array}{l}\text { Student } \\
\text { Participation }\end{array}$ & $\begin{array}{l}\text { Only a few students } \\
\text { participate in a } \\
\text { discussion or no } \\
\text { discussion occurs. }\end{array}$ & $\begin{array}{l}\text { Teacher attempts to } \\
\text { engage all students in } \\
\text { the discussion, but with } \\
\text { only limited success. }\end{array}$ & $\begin{array}{l}\text { Teacher successfully } \\
\text { engages all students in } \\
\text { discussion. }\end{array}$ & $\begin{array}{l}\text { Students themselves ensure that } \\
\text { all voices are heard in the } \\
\text { discussion. }\end{array}$ \\
\hline
\end{tabular}

Text on these pages adapted from ETS Pathwise materials 


\begin{tabular}{|c|c|c|c|c|}
\hline \multicolumn{5}{|c|}{ Component 3c: Engaging Students In Learning } \\
\hline \multirow[b]{2}{*}{ Element } & \multicolumn{4}{|c|}{ Level of Performance } \\
\hline & Unsatisfactory & Basic & Proficient & Distinguished \\
\hline $\begin{array}{l}\text { Instructional } \\
\text { Techniquess and } \\
\text { Resources }\end{array}$ & $\begin{array}{l}\text { Most of the time, } \\
\text { instructional materials } \\
\text { and resources are } \\
\text { unsuitable to the } \\
\text { instructional goals or } \\
\text { do not engage the } \\
\text { students mentally. } \\
\text { Many students are not } \\
\text { engaged in learning. }\end{array}$ & $\begin{array}{l}\text { Instructional materials } \\
\text { are somewhat suitable } \\
\text { to the instructional } \\
\text { goals, and over half of } \\
\text { students are mentally } \\
\text { engaged in learning. At } \\
\text { least some of the time } \\
\text { instructional techniques } \\
\text { succeed in engaging the } \\
\text { students in learning. }\end{array}$ & $\begin{array}{l}\text { Most of the instructional } \\
\text { materials and resources } \\
\text { are suitable to the } \\
\text { instructional goals and } \\
\text { engage students } \\
\text { mentally. Most students } \\
\text { are mentally engaged } \\
\text { during the teachers } \\
\text { lessons. }\end{array}$ & $\begin{array}{l}\text { Instructional materials and } \\
\text { resources are always suitable to } \\
\text { the instructional goals and } \\
\text { engage nearly all students } \\
\text { mentally. Students initiate the } \\
\text { choice, adaptation, or creation } \\
\text { of materials to enhance their } \\
\text { own learning. }\end{array}$ \\
\hline $\begin{array}{l}\text { Structure and } \\
\text { Pacing }\end{array}$ & $\begin{array}{l}\text { Lesson usually have no } \\
\text { clearly defined } \\
\text { structure, or the pacing } \\
\text { of the lesson is too slow } \\
\text { or rushed, or both. The } \\
\text { result is the } \\
\text { disengagement of many } \\
\text { students. }\end{array}$ & $\begin{array}{l}\text { Lessons have a } \\
\text { recognizable structure } \\
\text { throughout most of the } \\
\text { lessons. Pacing of the } \\
\text { lessons is sensitive to a } \\
\text { majority of students' } \\
\text { capabilities and these } \\
\text { students are consistently } \\
\text { engaged. }\end{array}$ & $\begin{array}{l}\text { Lessons have a clearly } \\
\text { defined structure around } \\
\text { which the activities are } \\
\text { organized. Pacing of } \\
\text { the lessons is consistent } \\
\text { and sensible to most of } \\
\text { the students resulting in } \\
\text { little mental } \\
\text { disengagement in the } \\
\text { class. }\end{array}$ & $\begin{array}{l}\text { Lesson structure is highly } \\
\text { coherent, allowing for } \\
\text { reflection and closure as } \\
\text { appropriate. Pacing is } \\
\text { consistently appropriate and } \\
\text { sensible to all students. Very } \\
\text { rarely do students seem } \\
\text { disengaged from learning. }\end{array}$ \\
\hline
\end{tabular}

\begin{tabular}{|l|l|l|l|l|}
\hline \multicolumn{2}{|l|}{ Component 3d: Providing Feedback to Students } \\
\hline \multirow{2}{*}{\begin{tabular}{l} 
Element \\
\cline { 2 - 5 } \\
\cline { 2 - 5 } \\
Feequency of
\end{tabular}} & $\begin{array}{l}\text { Unsatisfactory } \\
\text { Quality feedback is } \\
\text { rarely provided. }\end{array}$ & $\begin{array}{l}\text { Basic } \\
\text { Quality feedback is } \\
\text { occasionally given. }\end{array}$ & $\begin{array}{l}\text { Quality feedback is } \\
\text { frequently given. }\end{array}$ & $\begin{array}{l}\text { High quality feedback is } \\
\text { consistently given. Provision is } \\
\text { made to students to use } \\
\text { feedback in their own learning. }\end{array}$ \\
\hline Timneliness & $\begin{array}{l}\text { Feedback is not } \\
\text { provided in a timely } \\
\text { manner. }\end{array}$ & $\begin{array}{l}\text { Timeliness of feedback } \\
\text { is inconsistent. }\end{array}$ & $\begin{array}{l}\text { Feedback is consistently } \\
\text { provided in a timely } \\
\text { manner. }\end{array}$ & $\begin{array}{l}\text { Feedback is consistently } \\
\text { provided in a timely manner. } \\
\text { Students make prompt use of } \\
\text { the feedback in their learning. }\end{array}$ \\
\hline
\end{tabular}

\begin{tabular}{|c|c|c|c|c|}
\hline \multicolumn{5}{|c|}{ Component 3e: Demonstrating Flexibility and Responsiveness } \\
\hline \multirow[b]{2}{*}{ Element } & \multicolumn{4}{|c|}{ Level of Performance } \\
\hline & Unsatisfactory & Basic & Proficient & Distinguished \\
\hline $\begin{array}{l}\text { Lesson } \\
\text { Adjustment }\end{array}$ & $\begin{array}{l}\text { Teacher adheres rigidly } \\
\text { to instructional plan, } \\
\text { even when change } \\
\text { would improve lesson. }\end{array}$ & $\begin{array}{l}\text { Teacher attempts to } \\
\text { adjust lessons when } \\
\text { needed, but with mixed } \\
\text { results. }\end{array}$ & $\begin{array}{l}\text { Teacher makes minor } \\
\text { adjustments to lessons } \\
\text { when needed and the } \\
\text { changes occur } \\
\text { smoothly. }\end{array}$ & $\begin{array}{l}\text { Teacher successfully makes } \\
\text { major adjustments when } \\
\text { necessary. }\end{array}$ \\
\hline $\begin{array}{l}\text { Response } 10 \\
\text { Students }\end{array}$ & $\begin{array}{l}\text { Teacher ignores or } \\
\text { brushes aside students' } \\
\text { questions, interests, and } \\
\text { concerns in the interest } \\
\text { of inflexibly keeping to } \\
\text { his or her established } \\
\text { schedule or plan. }\end{array}$ & $\begin{array}{l}\text { Teacher reluctantly } \\
\text { attempts to } \\
\text { accommodate students' } \\
\text { questions, interests, and } \\
\text { concerns. The effects } \\
\text { on the coherence of a } \\
\text { lesson are uneven. }\end{array}$ & $\begin{array}{l}\text { Teacher successfully } \\
\text { accommodates students' } \\
\text { questions, interests, and } \\
\text { concerns. The teacher } \\
\text { uses discernment and } \\
\text { appears flexible. }\end{array}$ & $\begin{array}{l}\text { Teachers seizes students' } \\
\text { responses as major } \\
\text { opportunities to enhance } \\
\text { learning, building on } \\
\text { spontaneous events. } \\
\text { The teacher communicates that } \\
\text { he or she is flexible and } \\
\text { discerning. }\end{array}$ \\
\hline $\begin{array}{l}\text { Flexibility in } \\
\text { Scheduling }\end{array}$ & $\begin{array}{l}\text { Teacher balks when } \\
\text { asked to adjust or } \\
\text { refuses to adjust to } \\
\text { unexpected changes in } \\
\text { the schedule. }\end{array}$ & $\begin{array}{l}\text { Teacher reluctantly } \\
\text { makes changes when } \\
\text { necessary with some } \\
\text { success in the } \\
\text { classroom. }\end{array}$ & $\begin{array}{l}\text { Teacher successfully } \\
\text { makes changes with a } \\
\text { good spirit. }\end{array}$ & $\begin{array}{l}\text { Teacher communicates that he } \\
\text { or she is ready to make changes } \\
\text { to plans when necessary and } \\
\text { successfully makes those } \\
\text { changes. }\end{array}$ \\
\hline
\end{tabular}

Text on these pages adapted from ETS Pathwise materials 


\begin{tabular}{|c|c|c|c|c|}
\hline \multicolumn{4}{|c|}{ Component 3f: Biblical Worldview Integration } & (back to framework) \\
\hline \multirow[b]{2}{*}{ Element } & \multicolumn{4}{|c|}{ Level of Performance } \\
\hline & Unsatisfactory & Basic & Proficient & Distinguished \\
\hline $\begin{array}{l}\text { Biblical } \\
\text { Worldview } \\
\text { Integration }\end{array}$ & $\begin{array}{l}\text { There is no evidence of } \\
\text { Biblical worldview } \\
\text { integration in teacher's } \\
\text { instruction. }\end{array}$ & $\begin{array}{l}\text { Teacher occasionally } \\
\text { plans and teaches } \\
\text { subject with Biblical } \\
\text { world view integration. } \\
\text { Occasionally, there is a } \\
\text { Biblical focus in } \\
\text { instruction and } \\
\text { interaction. }\end{array}$ & $\begin{array}{l}\text { Teacher usually plans } \\
\text { and teaches subject } \\
\text { from a Biblically } \\
\text { focused worldview. } \\
\text { Fairly consistent } \\
\text { Biblical focus in } \\
\text { instruction and } \\
\text { interaction. }\end{array}$ & $\begin{array}{l}\text { Always plans and teaches with } \\
\text { a Biblically focused } \\
\text { perspective. Teacher assists } \\
\text { others in integrating a Biblical } \\
\text { worldview into their } \\
\text { instruction. }\end{array}$ \\
\hline
\end{tabular}

\section{Domain IV: Professional Responsibilities}

\begin{tabular}{|l|l|l|l|l|}
\hline \multirow{2}{*}{ Component 4a : Modeling a Christ-centered lifestyle } \\
\hline \multirow{4}{*}{$\begin{array}{l}\text { Element } \\
\text { Applical }\end{array}$} & Unsatisfactory & Basic & Proficient & Distinguished \\
\cline { 2 - 5 } & $\begin{array}{l}\text { Teacher is very } \\
\text { inconsistent in living by } \\
\text { Biblical principles. }\end{array}$ & $\begin{array}{l}\text { Teacher lives by } \\
\text { Biblical principles with } \\
\text { fair consistency. }\end{array}$ & $\begin{array}{l}\text { Teacher consistently } \\
\text { lives by Biblical } \\
\text { principles. }\end{array}$ & $\begin{array}{l}\text { Teacher very consistently lives } \\
\text { by Biblical principles and } \\
\text { encourages others to live by } \\
\text { Biblical principles. }\end{array}$ \\
\hline Christian Love & $\begin{array}{l}\text { Frequent incidents of } \\
\text { not evidencing Christian } \\
\text { love for others. }\end{array}$ & $\begin{array}{l}\text { Teacher generally } \\
\text { shows Christian love } \\
\text { with fair consistently. }\end{array}$ & $\begin{array}{l}\text { Teacher consistently } \\
\text { expresses Christian love } \\
\text { for others in the school } \\
\text { community. }\end{array}$ & $\begin{array}{l}\text { Teacher consistently makes } \\
\text { extraordinary effort to support } \\
\text { others with Christian love. }\end{array}$ \\
\hline Integrity & $\begin{array}{l}\text { Teacher has frequent } \\
\text { failures at maintaining } \\
\text { integrity. }\end{array}$ & $\begin{array}{l}\text { Teacher is generally } \\
\text { trustworthy and } \\
\text { honorable. }\end{array}$ & $\begin{array}{l}\text { Teacher is a good } \\
\text { example of consistent } \\
\text { Christian integrity. }\end{array}$ & $\begin{array}{l}\text { Teacher is not perfect, but very } \\
\text { consistently honors the Lord by } \\
\text { being an outstanding example } \\
\text { of Christian integrity. }\end{array}$ \\
\hline
\end{tabular}

Component 4b: Reflecting on Teaching

\begin{tabular}{|l|l|l|l|l|}
\hline \multirow{2}{*}{ Element } & \multicolumn{3}{|c|}{ Level of Performance } & Dack to framework \\
\cline { 2 - 5 } & Unsatisfactory & Basic & Proficient & Distinguished \\
\hline Accuracy & $\begin{array}{l}\text { Teacher does not know } \\
\text { if a lesson was } \\
\text { successful or if goals } \\
\text { were achieved, or } \\
\text { profoundly misjudges } \\
\text { the success of a lesson. }\end{array}$ & $\begin{array}{l}\text { Teacher has a generally } \\
\text { accurate impression of a } \\
\text { lesson's effectiveness } \\
\text { and the extent to which } \\
\text { instructional goals were } \\
\text { met. }\end{array}$ & $\begin{array}{l}\text { Teacher makes an } \\
\text { accurate assessment of a } \\
\text { lesson's effectiveness } \\
\text { and the extent to which } \\
\text { it achieved its goals and } \\
\text { can cite general } \\
\text { references to support the } \\
\text { judgment. }\end{array}$ & $\begin{array}{l}\text { Teacher makes a thoughtful } \\
\text { and accurate assessment of a } \\
\text { lesson's effectiveness and the } \\
\text { extent to which it achieved its } \\
\text { goals, citing many specific } \\
\text { examples from the lesson and } \\
\text { weighing the relative strength } \\
\text { of each. }\end{array}$ \\
\hline $\begin{array}{l}\text { Use in Futurc } \\
\text { Teaching }\end{array}$ & $\begin{array}{l}\text { Teacher has no } \\
\text { suggestions for how a } \\
\text { lesson may be improved } \\
\text { when used in the future. }\end{array}$ & $\begin{array}{l}\text { Teacher makes general } \\
\text { suggestions about how a a } \\
\text { lesson may be } \\
\text { improved. }\end{array}$ & $\begin{array}{l}\text { Teacher makes a few } \\
\text { specific suggestions of } \\
\text { what he or she may try } \\
\text { another time. }\end{array}$ & $\begin{array}{l}\text { Drawing on an extensive } \\
\text { repertoire of skills, the teacher } \\
\text { offers specific alternative } \\
\text { actions, complete with probable } \\
\text { successes of different } \\
\text { approaches. }\end{array}$ \\
\hline
\end{tabular}

Text on these pages adapted from ETS Pathwise materials 


\begin{tabular}{|c|c|c|c|c|}
\hline \multicolumn{4}{|c|}{ Component 4c: Communicating with Families } & (back to framework) \\
\hline \multirow[b]{2}{*}{ Element } & \multicolumn{4}{|c|}{ Level of Performance } \\
\hline & Unsatisfactory & Basic & Proficient & Distinguished \\
\hline $\begin{array}{l}\text { Information } \\
\text { about } \\
\text { instructional } \\
\text { program }\end{array}$ & $\begin{array}{l}\text { Teacher provides little } \\
\text { communication about } \\
\text { instructional program to } \\
\text { families. }\end{array}$ & $\begin{array}{l}\text { Teacher participates in } \\
\text { the school's activities } \\
\text { for basic parent } \\
\text { communication. }\end{array}$ & $\begin{array}{l}\text { Teacher goes beyond the } \\
\text { school basic } \\
\text { communication activities } \\
\text { to provide frequent } \\
\text { information to parents } \\
\text { about the instructional } \\
\text { program as appropriate. }\end{array}$ & $\begin{array}{l}\text { Teacher goes beyond the } \\
\text { school's basic communication } \\
\text { activities to provide frequent } \\
\text { information about the } \\
\text { instructional program. } \\
\text { Teacher attempts to find new } \\
\text { ways to enhance } \\
\text { communication with families. } \\
\text { Students participate in } \\
\text { preparing information. }\end{array}$ \\
\hline $\begin{array}{l}\text { Information } \\
\text { about } \\
\text { individual } \\
\text { students. }\end{array}$ & $\begin{array}{l}\text { Teacher provides } \\
\text { minimal information to } \\
\text { parents and does not } \\
\text { respond appropriately to } \\
\text { parent concerns about } \\
\text { students. }\end{array}$ & $\begin{array}{l}\text { Teacher adheres to the } \\
\text { school's basic } \\
\text { procedures for } \\
\text { communicating to } \\
\text { parents. }\end{array}$ & $\begin{array}{l}\text { Teacher communicates } \\
\text { with parents about } \\
\text { students' progress on a } \\
\text { regular basis and is } \\
\text { available as needed to } \\
\text { respond to parents. }\end{array}$ & $\begin{array}{l}\text { Teacher provides information } \\
\text { to parents frequently on both } \\
\text { positive and negative aspects } \\
\text { of student progress. Reponses } \\
\text { to parents are handled with } \\
\text { great sensitivity and result in } \\
\text { good will. }\end{array}$ \\
\hline
\end{tabular}

\begin{tabular}{|c|c|c|c|c|}
\hline \multicolumn{4}{|c|}{ Component 4d: Contributing to the School } & (back to framework) \\
\hline \multirow[b]{2}{*}{ Element } & \multicolumn{4}{|c|}{ Level of Performance } \\
\hline & Unsatisfactory & Basic & Proficient & Distinguished \\
\hline $\begin{array}{l}\text { Cooperation } \\
\text { with } \\
\text { colleagues }\end{array}$ & $\begin{array}{l}\text { Teacher's relationships } \\
\text { with colleagues are } \\
\text { negative or self-serving. }\end{array}$ & $\begin{array}{l}\text { Teacher maintains } \\
\text { cordial relationships } \\
\text { with colleagues to fulfill } \\
\text { the duties that the } \\
\text { school requires. }\end{array}$ & $\begin{array}{l}\text { Support and cooperation } \\
\text { characterize } \\
\text { relationships with most } \\
\text { colleagues. Teacher } \\
\text { shows Christian love for } \\
\text { most colleagues. }\end{array}$ & $\begin{array}{l}\text { Support and cooperation } \\
\text { characterize relationships with } \\
\text { all colleagues. Teacher shows } \\
\text { Christian love for all } \\
\text { colleagues. Teacher embraces } \\
\text { a leadership role among the } \\
\text { faculty. }\end{array}$ \\
\hline $\begin{array}{l}\text { Service to the } \\
\text { school }\end{array}$ & $\begin{array}{l}\text { Teacher avoids } \\
\text { involvement with school } \\
\text { teams, events and } \\
\text { projects and/or misses } \\
\text { some meetings and } \\
\text { required events without } \\
\text { being excused. }\end{array}$ & $\begin{array}{l}\text { Teacher coaches sports } \\
\text { teams, leads } \\
\text { organizations, and/or } \\
\text { participates in school } \\
\text { events and projects } \\
\text { when asked and rarely } \\
\text { misses meetings or } \\
\text { required events. }\end{array}$ & $\begin{array}{l}\text { Teacher volunteers to } \\
\text { coach sports teams, lead } \\
\text { organization, and/or } \\
\text { participate in school } \\
\text { events and projects, } \\
\text { making substantial } \\
\text { contributions. Teacher } \\
\text { very rarely misses } \\
\text { meetings or events. }\end{array}$ & $\begin{array}{l}\text { Teacher successfully leads } \\
\text { teams, organizations, events, } \\
\text { and meetings and provides } \\
\text { distinguished leadership, } \\
\text { communication, and/or } \\
\text { servanthood. Teacher very } \\
\text { rarely misses meetings or } \\
\text { events. }\end{array}$ \\
\hline $\begin{array}{l}\text { Involvement } \\
\text { in Spiritual } \\
\text { Activities }\end{array}$ & $\begin{array}{l}\text { Teacher does not } \\
\text { actively participate in } \\
\text { spiritual activities such } \\
\text { as chapel or advisory or } \\
\text { speaks negatively about } \\
\text { their value. }\end{array}$ & $\begin{array}{l}\text { Teacher participates in } \\
\text { and values chapel and } \\
\text { advisory. }\end{array}$ & $\begin{array}{l}\text { Teacher participates } \\
\text { whole-heartedly in } \\
\text { spiritual activities such } \\
\text { as chapel and advisory, } \\
\text { and expresses value of } \\
\text { these activities. }\end{array}$ & $\begin{array}{l}\text { Teacher initiates or leads } \\
\text { spiritual activities such as Bible } \\
\text { studies, prayer groups, and/or } \\
\text { outreach groups. Teacher } \\
\text { participates whole-heartedly in } \\
\text { chapels and advisory and } \\
\text { expresses their value. }\end{array}$ \\
\hline
\end{tabular}

\begin{tabular}{|c|c|c|c|c|}
\hline \multicolumn{5}{|c|}{ Component 4e: Following Christian Principles in Relationships } \\
\hline \multirow[b]{2}{*}{ Element } & \multicolumn{4}{|c|}{ Level of Performance } \\
\hline & Unsatisfactory & Basic & Proficient & Distinguished \\
\hline $\begin{array}{l}\text { Relationships } \\
\text { with others }\end{array}$ & $\begin{array}{l}\text { Teacher has frequent } \\
\text { conflicts with others. } \\
\text { He/She is easily } \\
\text { offended or has } \\
\text { problems maintaining } \\
\text { good relationships. }\end{array}$ & $\begin{array}{l}\text { Teacher has infrequent } \\
\text { conflicts with others. } \\
\text { Teacher's Christian love } \\
\text { for others shows. }\end{array}$ & $\begin{array}{l}\text { Teacher consistently } \\
\text { follows Christian } \\
\text { principles in } \\
\text { relationships. Very } \\
\text { infrequent conflicts. }\end{array}$ & $\begin{array}{l}\text { Teacher is a very consistent } \\
\text { Christ-like example of how to } \\
\text { relate to others in Christian } \\
\text { love. }\end{array}$ \\
\hline $\begin{array}{l}\text { Resolving } \\
\text { Conflict }\end{array}$ & $\begin{array}{l}\text { Teacher does not follow } \\
\text { Matthew } 18 \text { principle or } \\
\text { does not attempt to } \\
\text { resolve conflicts. }\end{array}$ & $\begin{array}{l}\text { Teacher follows } \\
\text { Matthew } 18 \text { principle } \\
\text { and quickly resolves } \\
\text { conflicts most of the } \\
\text { time. }\end{array}$ & $\begin{array}{l}\text { Teacher consistently } \\
\text { follows Matthew } 18 \\
\text { principle when conflicts } \\
\text { arise or conflicts are } \\
\text { very rare. }\end{array}$ & $\begin{array}{l}\text { Consistently follows Matthew } \\
18 \text { principle and encourages } \\
\text { others to follow it to resolve } \\
\text { conflict. }\end{array}$ \\
\hline Forgiveness & $\begin{array}{l}\text { Teacher holds grudges } \\
\text { and brings up past } \\
\text { offenses }\end{array}$ & $\begin{array}{l}\text { Teacher is usually quick } \\
\text { to forgive and does not } \\
\text { normally hold grudges. }\end{array}$ & $\begin{array}{l}\text { Teacher always forgives } \\
\text { others in Christian love. }\end{array}$ & $\begin{array}{l}\text { Teacher always forgives others } \\
\text { and also encourages others to } \\
\text { forgive. }\end{array}$ \\
\hline
\end{tabular}




\begin{tabular}{|l|l|l|l|l|}
\hline \multirow{2}{*}{$\begin{array}{l}\text { Component } \\
\text { Element }\end{array}$} & \multicolumn{3}{|c|}{ Level of Performance } \\
\cline { 2 - 5 } & Unsatisfactory & Basic & Proficient & Distinguished \\
\hline $\begin{array}{l}\text { Enhancement } \text { Content } \\
\text { Knowledge } \\
\text { and Teaching } \\
\text { Skill. }\end{array}$ & $\begin{array}{l}\text { Teacher engages in little } \\
\text { or no individual } \\
\text { professional } \\
\text { development and/or } \\
\text { avoids school-sponsored } \\
\text { professional } \\
\text { development }\end{array}$ & $\begin{array}{l}\text { Teacher participates in } \\
\text { school's professional } \\
\text { development as } \\
\text { required. }\end{array}$ & $\begin{array}{l}\text { Teacher seeks our } \\
\text { opportunities for } \\
\text { professional } \\
\text { development to enhance } \\
\text { content knowledge } \\
\text { and/or teaching skills. }\end{array}$ & $\begin{array}{l}\text { Teacher seeks out opportunities } \\
\text { for professional development to } \\
\text { enhance content knowledge } \\
\text { and/or teaching skills and } \\
\text { demonstrates use of content } \\
\text { and skills in the school }\end{array}$ \\
\hline $\begin{array}{l}\text { Service to the } \\
\text { Profession }\end{array}$ & $\begin{array}{l}\text { Teacher makes little or } \\
\text { no effort to share } \\
\text { knowledge with others } \\
\text { or to assume } \\
\text { professional } \\
\text { responsibilities such as } \\
\text { mentoring new teachers. }\end{array}$ & $\begin{array}{l}\text { Teacher finds a few } \\
\text { ways to contribute to the } \\
\text { profession. Teacher } \\
\text { occasionally assists new } \\
\text { or needy teachers in a } \\
\text { mentoring relationship. }\end{array}$ & $\begin{array}{l}\text { Teacher participates } \\
\text { frequently in assisting } \\
\text { other educators. } \\
\text { Teacher frequently } \\
\text { assists new or needy } \\
\text { teachers professionally. }\end{array}$ & $\begin{array}{l}\text { Teacher initiates important } \\
\text { activities to contribute } \\
\text { successfully to the profession, } \\
\text { such as mentoring new and } \\
\text { needy teachers, writing articles, } \\
\text { and making presentations. }\end{array}$ \\
\hline
\end{tabular}

\begin{tabular}{|c|c|c|c|c|}
\hline \multicolumn{4}{|c|}{ Component 4g: Growing in Discipleship } & \multirow[t]{2}{*}{ (back to framework) } \\
\hline & \multicolumn{3}{|c|}{ Level of Performance } & \\
\hline Element & Unsatisfactory & Basic & Proficient & Distinguished \\
\hline $\begin{array}{l}\text { Church } \\
\text { Involvement }\end{array}$ & $\begin{array}{l}\text { Teacher rarely or never } \\
\text { attends church services. }\end{array}$ & $\begin{array}{l}\text { Teacher attends church } \\
\text { services frequently. }\end{array}$ & $\begin{array}{l}\text { Teacher attends weekly } \\
\text { services, and sometimes } \\
\text { takes opportunities to } \\
\text { get involved in ministry. }\end{array}$ & $\begin{array}{l}\text { Teacher attends weekly } \\
\text { services and leads or } \\
\text { contributes regularly to the } \\
\text { church's ministries. }\end{array}$ \\
\hline Devotional life & $\begin{array}{l}\text { Devotional time of } \\
\text { prayer and Bible } \\
\text { reading is absent from } \\
\text { the teacher's life. }\end{array}$ & $\begin{array}{l}\text { Occasionally, the } \\
\text { teacher has a time of } \\
\text { personal prayer and } \\
\text { Bible reading. }\end{array}$ & $\begin{array}{l}\text { Teacher consistently has } \\
\text { a time of personal } \\
\text { prayer and Bible } \\
\text { reading. }\end{array}$ & $\begin{array}{l}\text { Teacher very consistently has } \\
\text { personal devotions and shares } \\
\text { blessing with others in class, } \\
\text { teacher devotions, and } \\
\text { advisory. Teacher encourages } \\
\text { others to grow in Christ } \\
\text { through their personal prayer } \\
\text { and Bible reading. }\end{array}$ \\
\hline Fellowship & $\begin{array}{l}\text { Christian fellowship is } \\
\text { absent from the } \\
\text { teacher's life. }\end{array}$ & $\begin{array}{l}\text { Teacher has some } \\
\text { interaction with other } \\
\text { Christians }\end{array}$ & $\begin{array}{l}\text { Teacher has a group of } \\
\text { Christian friends who } \\
\text { frequently provide } \\
\text { fellowship for one } \\
\text { another. }\end{array}$ & $\begin{array}{l}\text { Teacher is very involved in } \\
\text { fellowship with others and } \\
\text { seeks to extend Christian } \\
\text { fellowship to those in need. }\end{array}$ \\
\hline
\end{tabular}

\begin{tabular}{|c|c|c|c|c|}
\hline \multicolumn{4}{|c|}{ Component 4h: Showing Professionalism } & \multirow[t]{2}{*}{ (back to framework) } \\
\hline \multirow[b]{2}{*}{ Element } & \multicolumn{3}{|c|}{ Level of Performance } & \\
\hline & Unsatisfactory & Basic & Proficient & Distinguished \\
\hline Punctuality & $\begin{array}{l}\text { Frequent lateness in } \\
\text { turning in school-related } \\
\text { documents and grades. } \\
\text { Teacher is frequently } \\
\text { late to classes and } \\
\text { meetings. }\end{array}$ & $\begin{array}{l}\text { Normally, teacher turns } \\
\text { in grades and school- } \\
\text { related documents on } \\
\text { time. Teacher is rarely } \\
\text { late to classes and } \\
\text { meetings. }\end{array}$ & $\begin{array}{l}\text { Teacher nearly always } \\
\text { turns in grades and } \\
\text { school-related } \\
\text { documents on time. } \\
\text { Teacher is very rarely } \\
\text { late to classes and } \\
\text { meetings. }\end{array}$ & $\begin{array}{l}\text { Teacher always turns in grades } \\
\text { and school-related documents } \\
\text { early or on time. Teacher } \\
\text { normally arrives early for } \\
\text { classes and meetings. }\end{array}$ \\
\hline Advocacy & $\begin{array}{l}\text { Teacher contributes to } \\
\text { school practices that } \\
\text { result in some students } \\
\text { being ill-served by the } \\
\text { school or disparages } \\
\text { efforts to help all } \\
\text { students succeed. }\end{array}$ & $\begin{array}{l}\text { Teacher contributes as } \\
\text { required to meeting } \\
\text { special students' needs. }\end{array}$ & $\begin{array}{l}\text { Teacher contributes } \\
\text { substantially to meeting } \\
\text { special needs of } \\
\text { students beyond } \\
\text { requirements of the } \\
\text { school's program. }\end{array}$ & $\begin{array}{l}\text { Teacher makes particular effort } \\
\text { to challenge negative attitudes } \\
\text { about special student needs } \\
\text { and/or contributes time and } \\
\text { effort above and beyond to } \\
\text { honor and serve students with } \\
\text { special needs. }\end{array}$ \\
\hline $\begin{array}{l}\text { Appearance } \\
\text { and Demeanor }\end{array}$ & $\begin{array}{l}\text { Does not follow the } \\
\text { dress/hair code and/or } \\
\text { appears unprofessional } \\
\text { in classroom setting. } \\
\text { Appearance is } \\
\text { frequently sloppy. Acts } \\
\text { unbecoming of a } \\
\text { professional role model. }\end{array}$ & $\begin{array}{l}\text { Normally follows the } \\
\text { school dress/hair code } \\
\text { and behaves as a basic } \\
\text { role model. Rarely } \\
\text { appears sloppy or } \\
\text { unprofessional. }\end{array}$ & $\begin{array}{l}\text { Balances the role of } \\
\text { professional with the } \\
\text { role of advocate and } \\
\text { role model. Always } \\
\text { follows the school's } \\
\text { dress/hair code for } \\
\text { teachers. Normally } \\
\text { appears neat and } \\
\text { professional. }\end{array}$ & $\begin{array}{l}\text { Teacher makes a particular } \\
\text { effort to challenge negative } \\
\text { student and collegial attitudes } \\
\text { about the dress code. Always } \\
\text { follows the school's dress/hair } \\
\text { code for teachers. Always } \\
\text { appears neat and professional. }\end{array}$ \\
\hline
\end{tabular}




\begin{tabular}{|c|c|c|c|c|}
\hline \multicolumn{5}{|c|}{ Component 4i: Maintaining Accurate Records } \\
\hline \multirow[b]{2}{*}{ Element } & \multicolumn{4}{|c|}{ Level of Performance } \\
\hline & Unsatisfactory & Basic & Proficient & Distinguished \\
\hline $\begin{array}{l}\text { Student } \\
\text { Completion of } \\
\text { Assignments }\end{array}$ & $\begin{array}{l}\text { Teacher's system for } \\
\text { maintaining information } \\
\text { about students' } \\
\text { complete of assignments } \\
\text { is in disarray. There is } \\
\text { no system for getting } \\
\text { make-up work in. }\end{array}$ & $\begin{array}{l}\text { Teacher has a partially } \\
\text { effective system for } \\
\text { maintaining information } \\
\text { about students' } \\
\text { completion of } \\
\text { assignments. A partially } \\
\text { effective system for } \\
\text { collecting make-up work } \\
\text { is also in place. }\end{array}$ & $\begin{array}{l}\text { Teacher's system for } \\
\text { maintaining } \\
\text { information about } \\
\text { students' completion of } \\
\text { assignments is fully } \\
\text { effective. A very } \\
\text { effective system for } \\
\text { getting make-up work } \\
\text { in is in place. }\end{array}$ & $\begin{array}{l}\text { Teacher's system for } \\
\text { maintaining information about } \\
\text { students' completion of } \\
\text { assignments is fully effective. } \\
\text { Students participate in keeping } \\
\text { records and getting make-up } \\
\text { work done in a timely manner. }\end{array}$ \\
\hline $\begin{array}{l}\text { Student } \\
\text { Progress in } \\
\text { Leaurning. }\end{array}$ & $\begin{array}{l}\text { Teacher has no system } \\
\text { for maintaining } \\
\text { information on student } \\
\text { progress in learning, or } \\
\text { the system is in } \\
\text { disarray. Information-- } \\
\text { if there is any--is } \\
\text { inaccurate. }\end{array}$ & $\begin{array}{l}\text { Teacher has a partially } \\
\text { effective system for } \\
\text { maintaining information } \\
\text { about student progress. } \\
\text { Information is } \\
\text { sometimes accurate and } \\
\text { up-to-date. }\end{array}$ & $\begin{array}{l}\text { Teacher's system for } \\
\text { maintaining } \\
\text { information on student } \\
\text { progress in learning is } \\
\text { effective. Information } \\
\text { is usually accurate and } \\
\text { up-to-date. }\end{array}$ & $\begin{array}{l}\text { Teacher's system for } \\
\text { maintaining information on } \\
\text { student progress in learning is } \\
\text { fully effective. Information is } \\
\text { nearly always accurate and up- } \\
\text { to-date. }\end{array}$ \\
\hline $\begin{array}{l}\text { Non- } \\
\text { instructional } \\
\text { Records. }\end{array}$ & $\begin{array}{l}\text { Teacher's records for } \\
\text { non-instructional } \\
\text { activities are in disarray, } \\
\text { resulting in errors, } \\
\text { confusion, and } \\
\text { complaints. }\end{array}$ & $\begin{array}{l}\text { Teacher's records for } \\
\text { non-instructional } \\
\text { activities are adequate } \\
\text { and somewhat effective. }\end{array}$ & $\begin{array}{l}\text { Teacher's system for } \\
\text { maintaining } \\
\text { information on non- } \\
\text { instructional activities } \\
\text { is fully effective. }\end{array}$ & $\begin{array}{l}\text { Teacher's system for } \\
\text { maintaining information on } \\
\text { non-instructional activities is } \\
\text { fully effective. Students assist } \\
\text { in keeping records. }\end{array}$ \\
\hline
\end{tabular}

Text on these pages adapted from ETS Pathwise materials 
School Name

Observation Reflection Form

Name Grade / Subject

Observation Date Time

1. To what degree was I a spiritual inspiration to my students? To what degree did I weave a Biblical worldview into my lesson? (2f and $3 \mathrm{f}$ )

2. How well was I prepared for the lesson that was observed? Were the students prepared in terms of background knowledge, class environment, and motivation? (Component 1b, 1d, 1e, 2b)

3. As I reflect on the lesson that was observed, to what extent were my students productively engaged in learning? (Components $4 \mathrm{a}, 1 \mathrm{e}, 3 \mathrm{c}$ )

4. How well did the students learn what I intended? Were my instructional goals met? How do I know? (Components 1f, 4a)

5. How well did I manage non-instructional duties such as attendance, restroom permissions, etc? What attention does my room need to make it a better learning environment? (Components $2 \mathrm{c}$ and 2e) 
6. To what degree do the students feel safe, respected, and loved in this class? How do I know? (Component 2a and 2d)

7. If I had the opportunity to teach the same lesson again to the same group of students, what would I do differently? Why? (Component 4a) 


\section{APPENDIX B}

\section{Survey used to acquire data for this study:}

\section{Survey of Teacher Attitudes Toward Teacher Evaluation and Professional Development}

Researcher: Joe Batchelor -- Cedarville University

$>$ Your assistance with this survey is greatly appreciated. Please do not sign your name. No reference to your school or to you will be made in discussion of the results of this survey.

Demographics (Please check all that apply)

\section{Gender}

Male

Female

1. I am currently employed as a (n)

Part-time teacher

Full-time teacher

Teacher aide

Teaching Administrator

Para-professional

Other

2. I have taught for

0 - 1 year

$2-4$ years

$5-10$ years

$11-20$ years

$21+$ years

3. The majority of my teaching career has been in public schools private non-sectarian schools Christian / Religious schools Other schools

4. My current school includes the following grades (Please check all that apply)

Pre-K

Kindergarten

$1^{\text {st }}$ grade

$2^{\text {nd }}$ grade

$3^{\text {rd }}$ grade $4^{\text {th }}$ grade

$5^{\text {th }}$ grade

$6^{\text {th }}$ grade

$7^{\text {th }}$ grade

$8^{\text {th }}$ grade

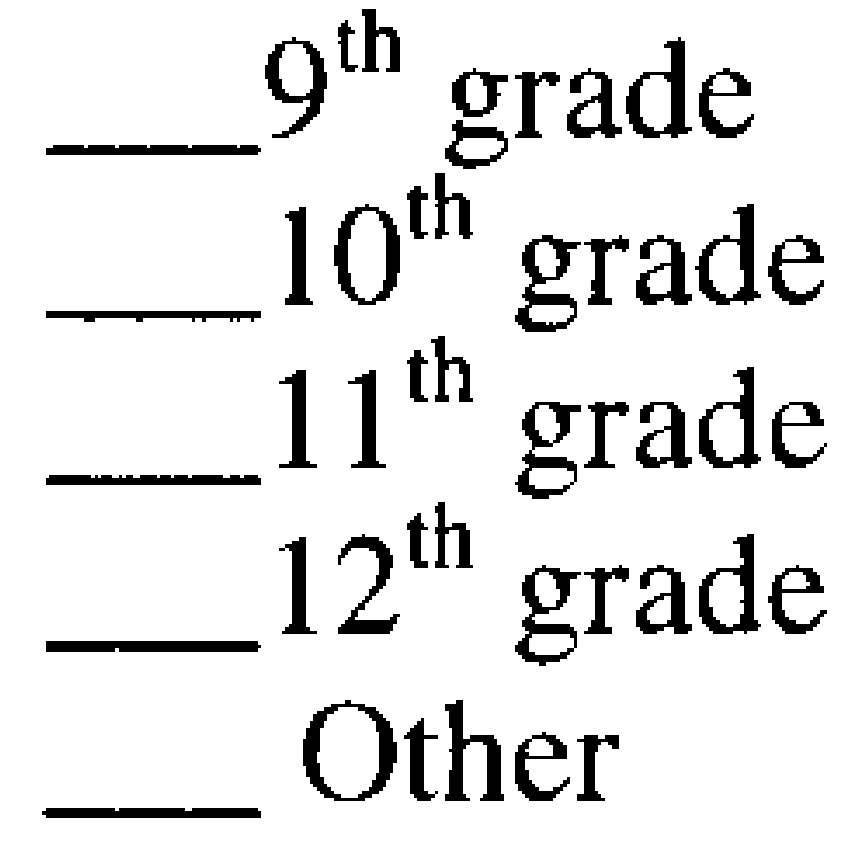

$9^{\text {th }}$ grade

$10^{\text {th }}$ grade

Other

5. My teaching assignment includes the following level(s) of students. (Please check all that apply)

Pre-K

Kindergarten

$1^{\text {st }}$ grade

$2^{\text {nd }}$ grade

$3^{\text {rd }}$ grade $4^{\text {th }}$ grade

$5^{\text {th }}$ grade

$6^{\text {th }}$ grade

$7^{\text {th }}$ grade

$8^{\text {th }}$ grade $9^{\text {th }}$ grade

$10^{\text {th }}$ grade

$11^{\text {th }}$ grade

$12^{\text {th }}$ grade

Other 
5. My teaching assignment includes the following subject(s)
English / Language Arts
Reading
Spelling
Math
Social Studies / History
Science
Computer
Bible / Religion
Foreign Languages
Speech / Drama
Vocational Education
Special Education

P.E

Music

Art

Speech

Drama / Theater

Vocations

Special Education

Other (Please list)

6. My college training included

An undergraduate degree in teacher education.

A teaching internship or student teaching

Undergraduate coursework in teacher education

A bachelor's degree with no coursework in teacher education

Graduate courses in education.

Graduate courses, but not in education

A master's degree in education.

A master's degree, but not in education.

7. What kind certification does your school or district require?

State certification, credential, or licensure

Christian school association certification (ACSI, CSI, AACS, SBCSA, etc.)

Private or independent school association certification

Other

No certification

Don't know 


\section{Teacher Perceptions of Evaluation and Professional Development}

The following survey questions relate to your perceptions of supervision, evaluation, and professional development in your school or district.

Note: In the following items, the terms appraisal and evaluation are used interchangeably.

Please circle your response to the following statements as follows:

SD. Strongly disagree

D. Disagree

N. Neither agree nor disagree

A. Agree

SA. Strongly Agree

1. As a beginning teacher, I felt / feel I was prepared though my undergraduate training to enter the field of education.

2. Our school / district has an effective teacher induction / mentoring program to support new teachers.

3. The administration in my school evaluates teachers with good frequency.

4. I wish that lead teachers or department heads would observe my classroom more.

5. When I am observed, I am given helpful feedback about how I am doing in my teaching.

6. When I am observed, the observers seem to be watching both teacher (me and the environment) and learners (my students and their activities).

7. I wish the principal or assistant principal would observe my classroom more.

8. During formal evaluations, I feel I have sufficient input as my evaluators complete the appraisal process.

9. As far as I know, formal evaluations are fair at my school (i.e. no preferential treatment for gender, race, age, etc.)

10. I believe that my lead teachers and department heads are qualified to judge my competency in my grade level and/or with my subject.

11. Teacher evaluations are thorough and professional at my school.

12. I believe that my principal and assistant principal are qualified to judge my competency in my grade level and/or with my subject.

13. At my school, standards for evaluation are clearly explained.

14. I believe that my teacher evaluations have helped me to improve as a professional educator.

15. My teacher evaluations usually contain a good balance between encouraging positive comments and suggestions for improvement and growth.

16. My evaluations have sufficient positive comments and encouraging feedback.

17. My evaluations have enough suggestions for improvement.

18. Professional development activities at my school -- such as pre-service, inservice, conventions, etc. -- help me to be more effective in my classroom.

19. My evaluations have been used to direct individual professional development activities that have helped me as a teacher.

20. I am satisfied with the professional development program in my school / district.

$\begin{array}{lllll}\text { SD } & \text { D } & \text { N } & \text { A } & \text { SA } \\ \text { SD } & \text { D } & \text { N } & \text { A } & \text { SA } \\ \text { SD } & \text { D } & \text { N } & \text { A } & \text { SA } \\ \text { SD } & \text { D } & \text { N } & \text { A } & \text { SA } \\ \text { SD } & \text { D } & \text { N } & \text { A } & \text { SA } \\ \text { SD } & \text { D } & \text { N } & \text { A } & \text { SA } \\ \text { SD } & \text { D } & \text { N } & \text { A } & \text { SA } \\ \text { SD } & \text { D } & \text { N } & \text { A } & \text { SA } \\ \text { SD } & \text { D } & \text { N } & \text { A } & \text { SA } \\ \text { SD } & \text { D } & \text { N } & \text { A } & \text { SA } \\ \text { SD } & \text { D } & \text { N } & \text { A } & \text { SA } \\ \text { SD } & \text { D } & \text { N } & \text { A } & \text { SA } \\ \text { SD } & \text { D } & \text { N } & \text { A } & \text { SA } \\ \text { SD } & \text { D } & \text { N } & \text { A } & \text { SA } \\ \text { SD } & \text { D } & \text { N } & \text { A } & \text { SA } \\ \text { SD } & \text { D } & \text { N } & \text { A } & \text { SA } \\ \text { SD } & \text { D } & \text { N } & \text { A } & \text { SA } \\ \text { SD } & \text { D } & \text { N } & \text { A } & \text { SA } \\ \text { SD } & \text { D } & \text { N } & \text { A } & \text { SA }\end{array}$

